"كهكشان هاست در ولايت بان"

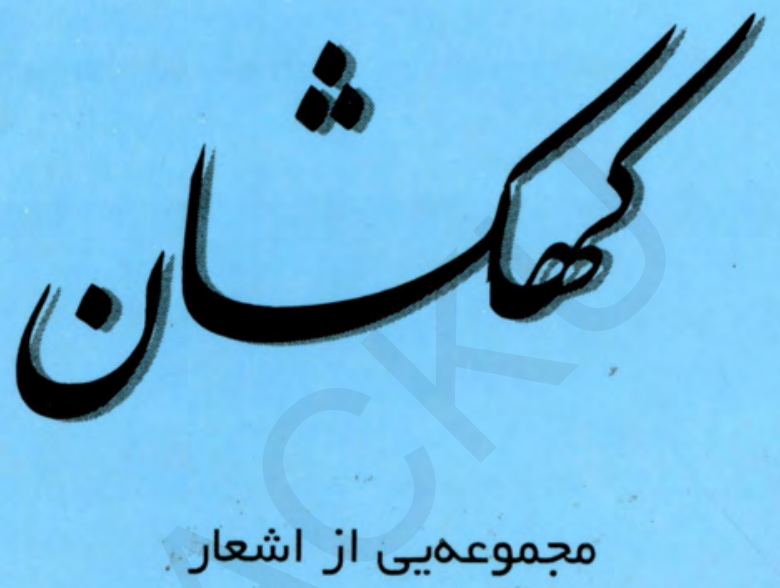

يوهاند دوكتور محمد حسين ״يمين) 


$$
\text { , كهكشان هاست در ولايت جاني, }
$$

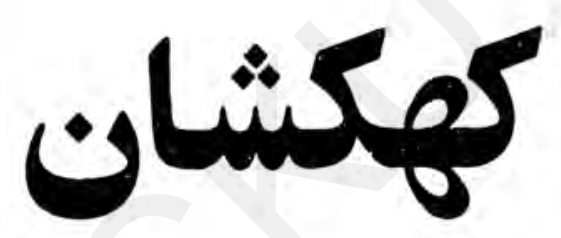

$$
\text { مجموعد يم از اشعار }
$$
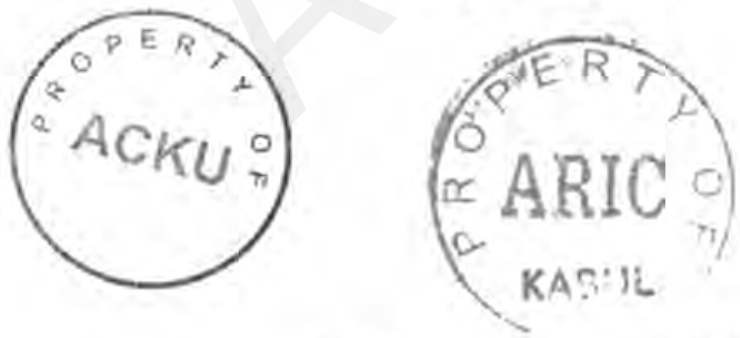

$$
\text { بوهاند دوكتور محمدحسين " (يمين }
$$

$$
\text { زمستان برrا خورشيدى }
$$




\section{مشخصات كتاب:}

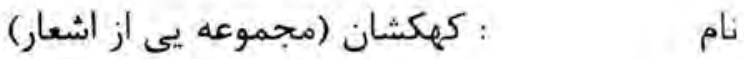

$$
\begin{aligned}
& \text { : يوهاند دوكتور محمد حسين "يمين : } \\
& \text { شاعر }
\end{aligned}
$$

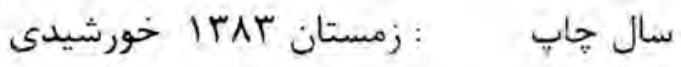

$$
\begin{aligned}
& \text { تيرارٔ. }
\end{aligned}
$$

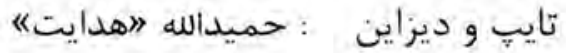




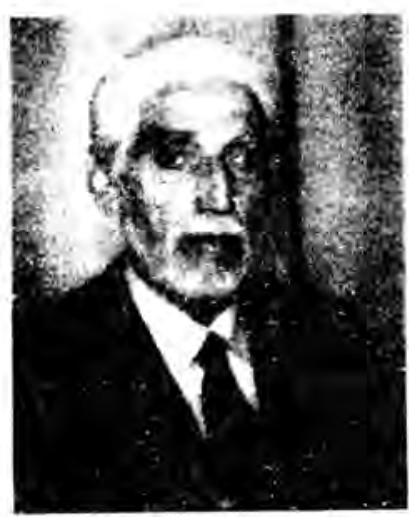

فُشر ده ريستنامئ يروفيسور دوكتور محمد حسين بمين

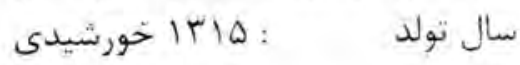

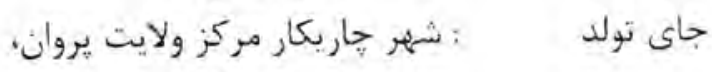
ناحية اول كذر آقايى

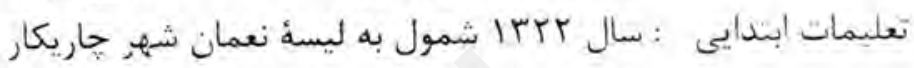

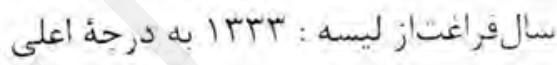

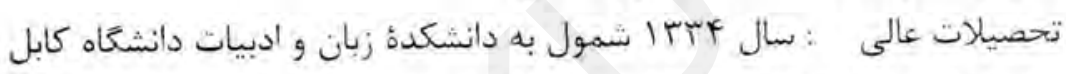

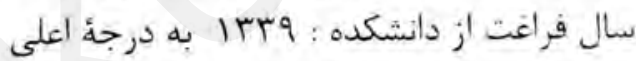

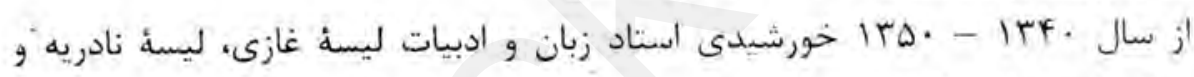

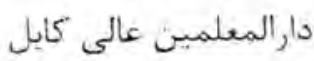

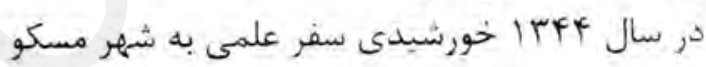

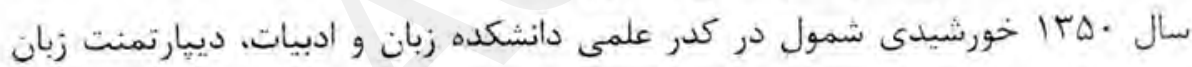

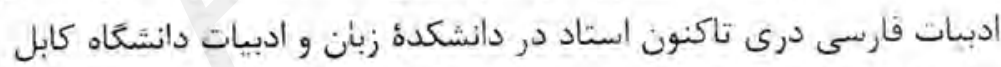
تحصيلات مافوق لسانس (دورة ماسترى و د دكتورا):

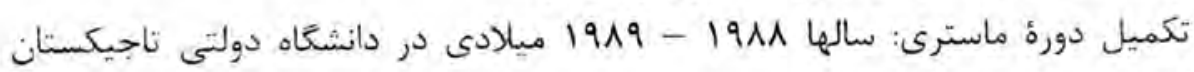
اتحاد شوروى سابق دورة ماستري

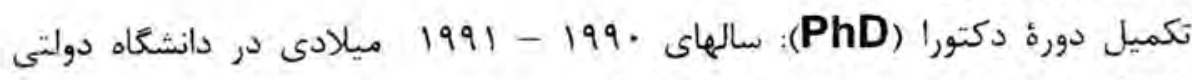

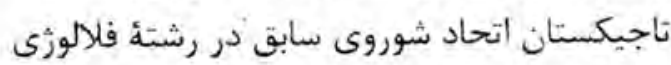

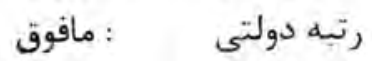

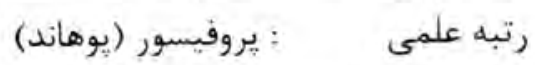

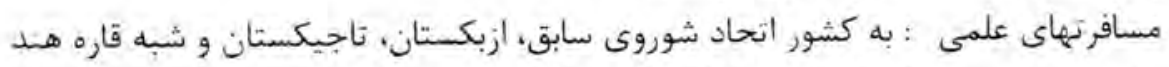
رشُه تدريس در دانشكده زبان و ادبيات دانشعاه كابل: زبانشناسى انسي. 
بخستهاى تدريس : دستور ربان فارسى درى صرف. دسنور زبان فارسى درى نحو، وارزه

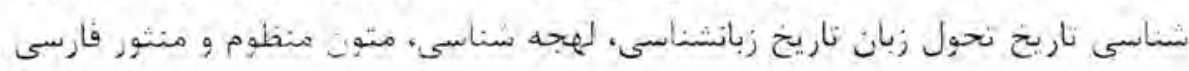

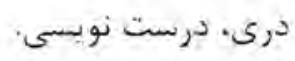
كار هاى فرا وظيفه يى دئ:

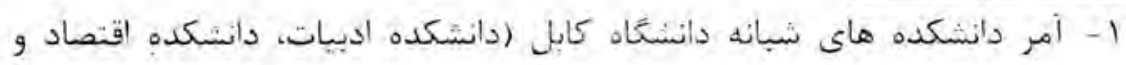

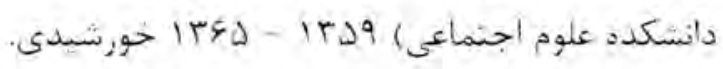

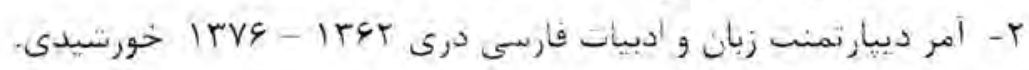

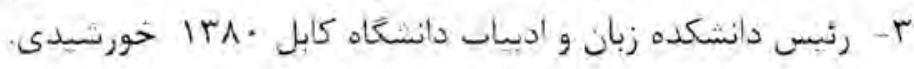

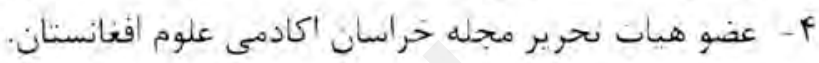

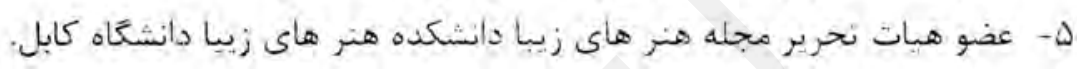

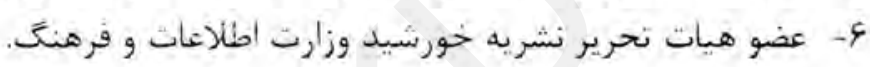

V- عضوى هيات تحرير مجله خيلواكى (مركز تحقيقات افغانستان).

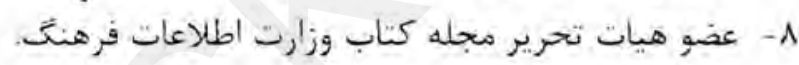

9- عضو شوراى علمى دانشئاه كابلى

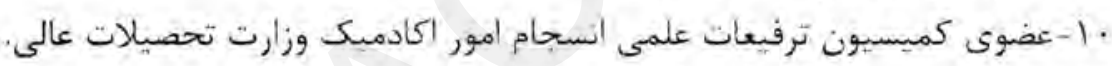

$$
\text { 1ا-عضو ييوسته فرهنَّنان زبان و ادب فارسى تهرئن. }
$$

\section{كتابهاى حابٍ و نشرشده يروفيسور دوكتور محمد حسين "يمين" :}

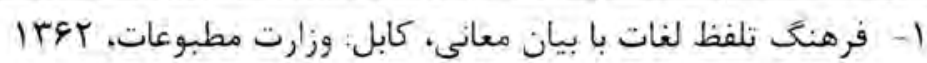

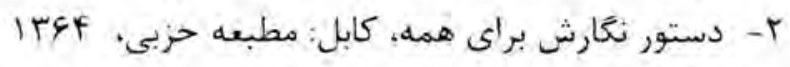

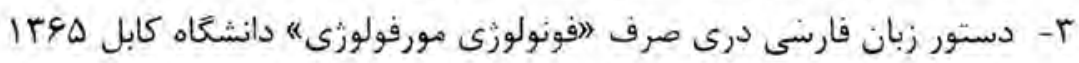

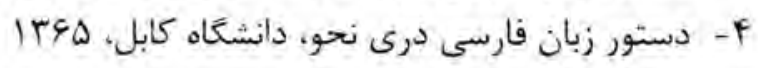

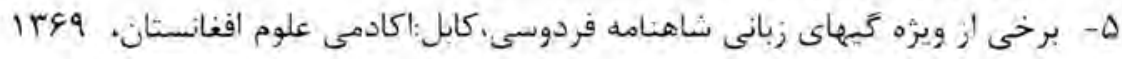

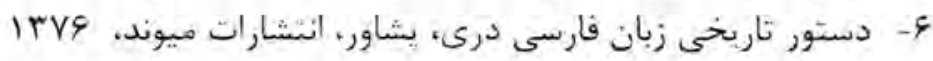

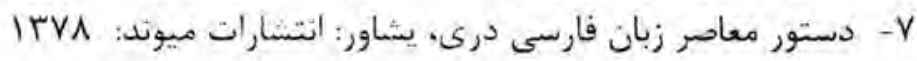

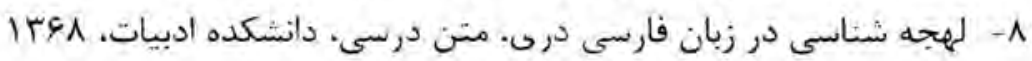




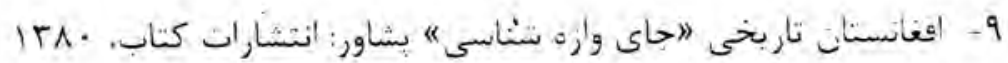

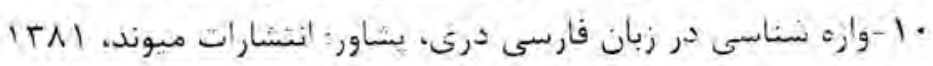

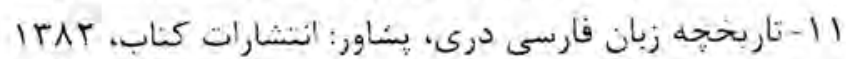

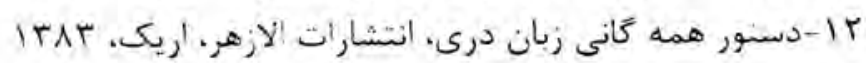

آثار علمى - تحقيقى نشر شده يروفيسور دكتور محمد حسين "يمين" در

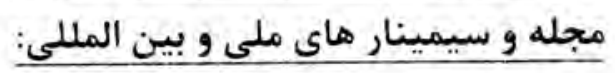

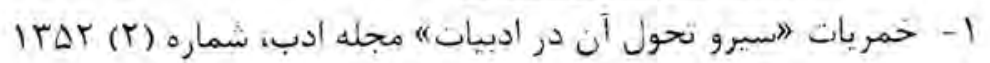

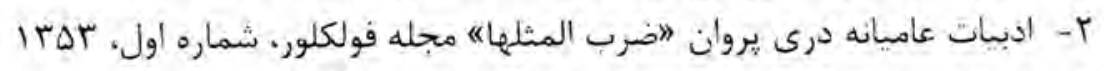

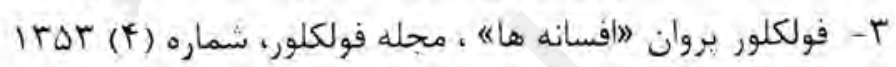

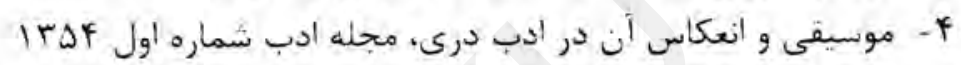

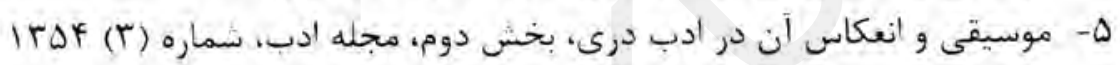

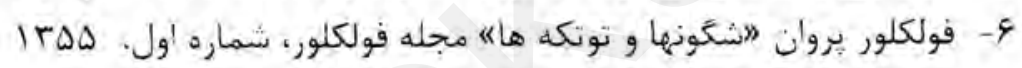

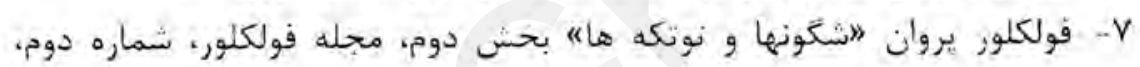
irod

1) فولكلور بروان "اشكونها و توتكه ها" بخش سوم، مجله فولكلور، شماره (f) irod

9 - سيد جمال الدين افغانى واقبال. حوانش در سيمينار بين المللى، م مين سال وفات سيد، ونهات

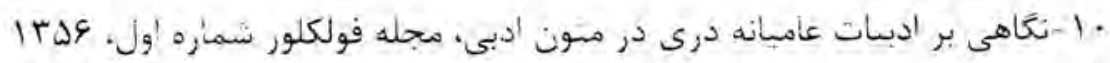

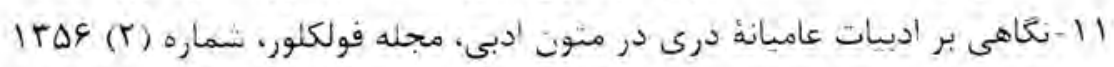

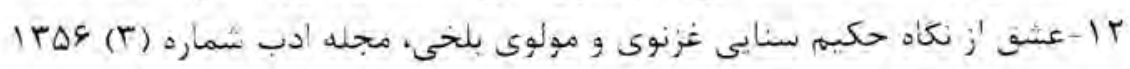

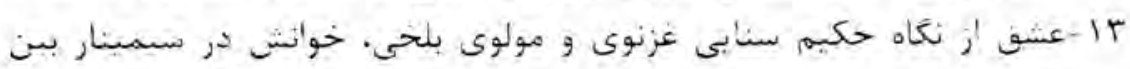

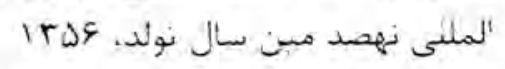

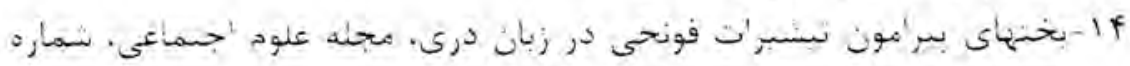
1मF. (T) 
ه - بخجباتى يبرامون تغيبرات فونيمى زبان درى، بخش دوم، مجله علوم اجتماعى.

$$
\text { 1TG. (T) o oin }
$$

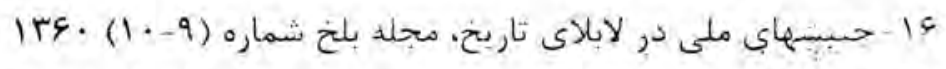

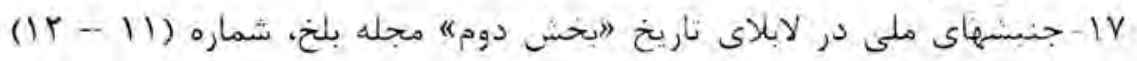
ITS.

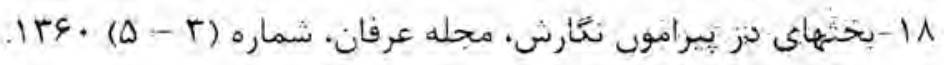

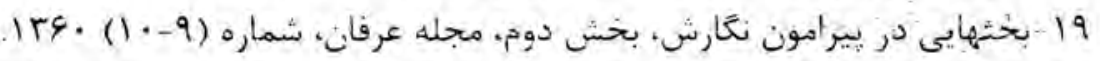

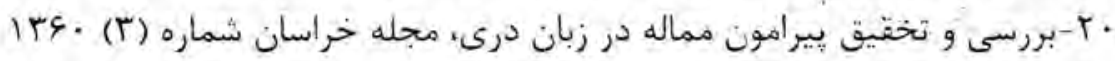

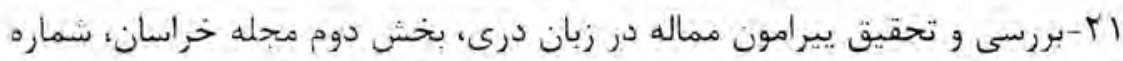
IrG. (f)

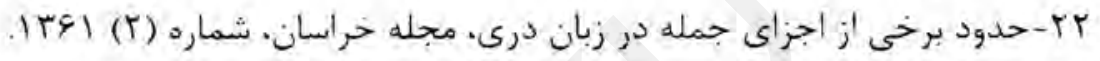

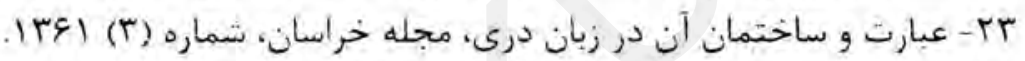

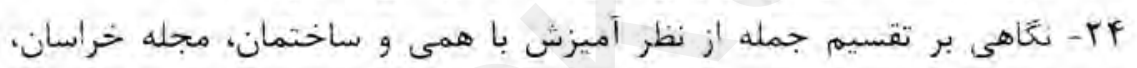

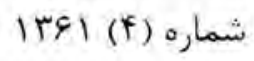

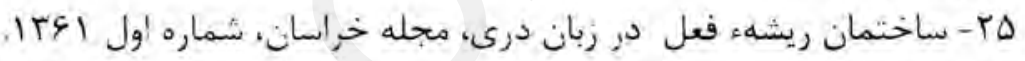

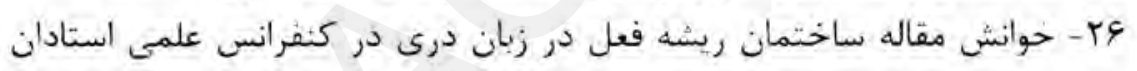

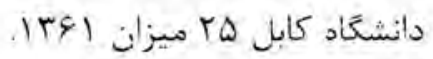

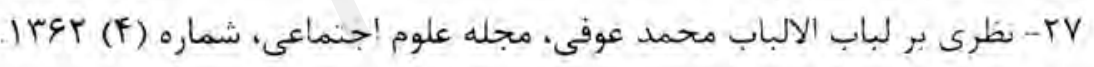

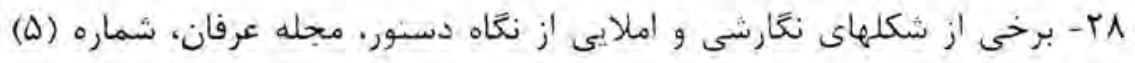
I HaY

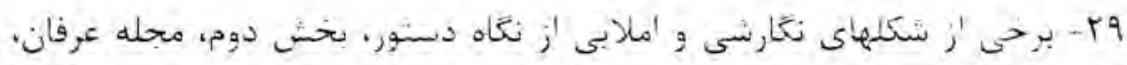
شor

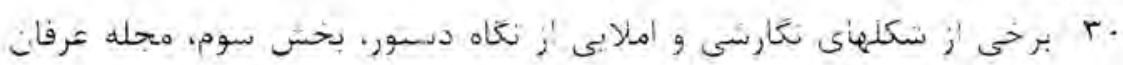

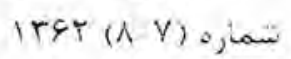

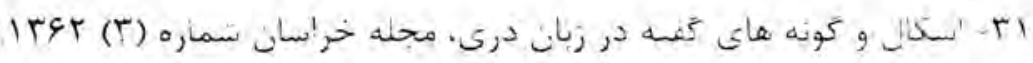

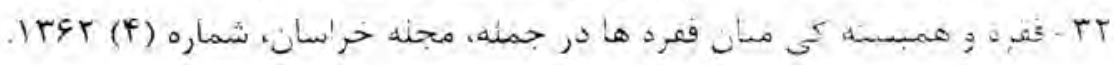




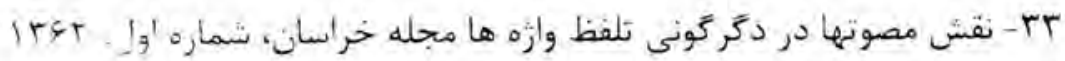
1) 1) مباه IreT (r

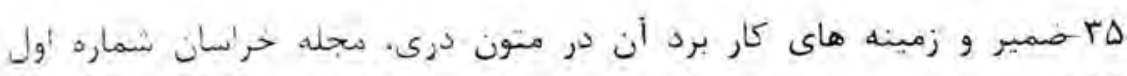
IreT

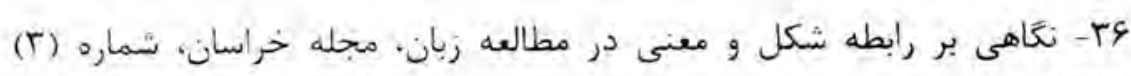
IrG

(9) جمع و دكركونيهاى تاريخى أن در زبان درى، مجله خراسان، شماره IrET

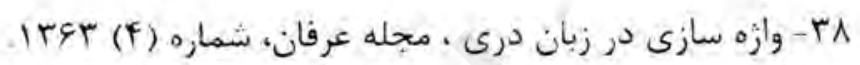

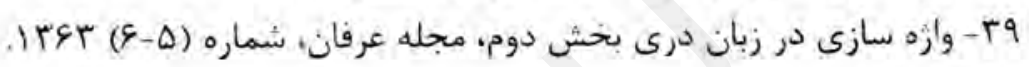

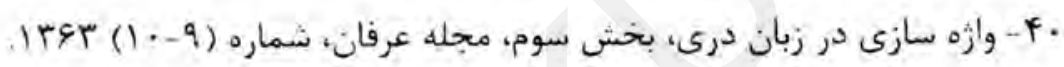

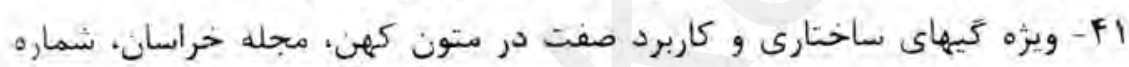
IrGF (r)

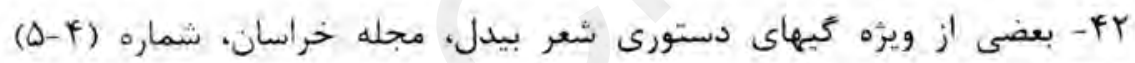
Irat

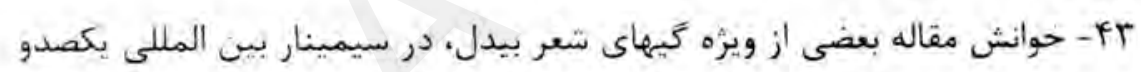

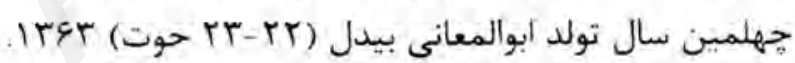

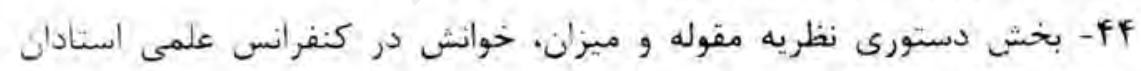

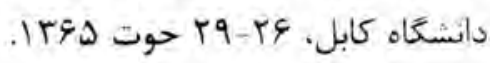

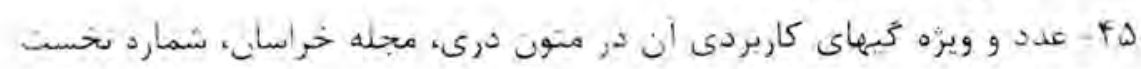
ITAS

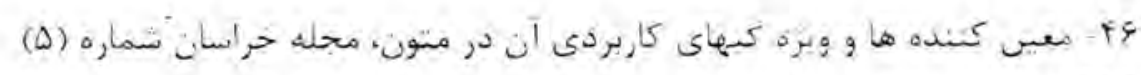
ITAO

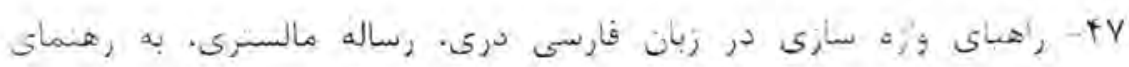

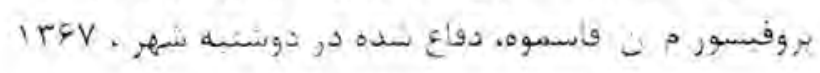




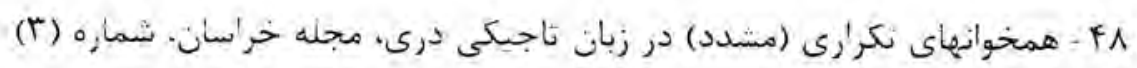
1 rद

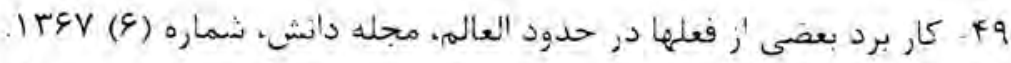

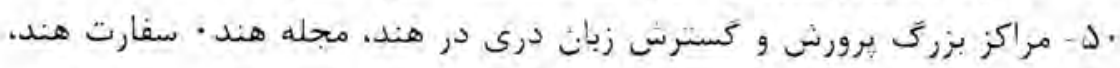

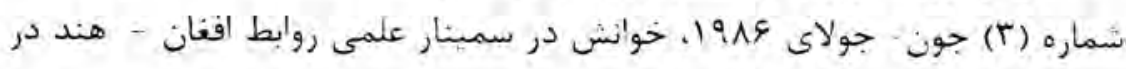

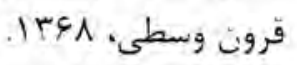
الم- ويرَه كيهاى دسنورى سفرنامه ناصر حسرو، مجموعه مقالات ناصر خسرو،

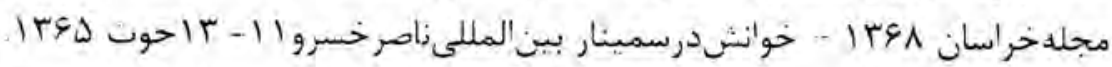

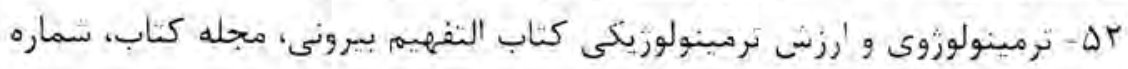
IrVA.

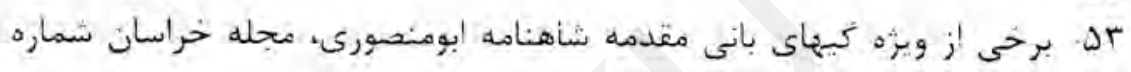
اول

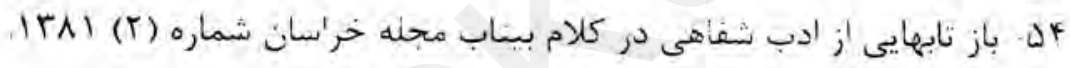

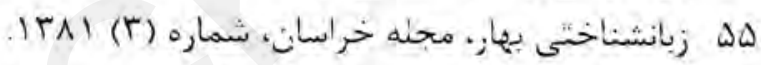

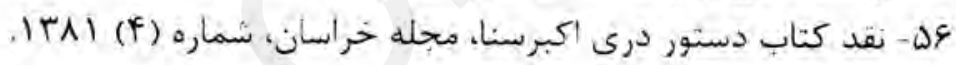

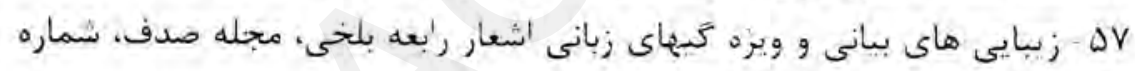
1 1 $11(T \cdot 19)$

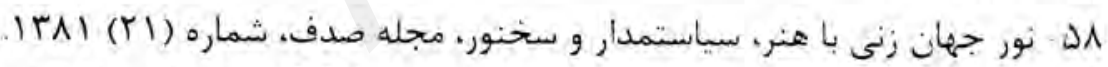

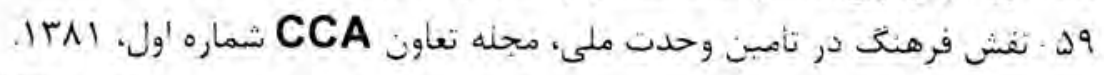

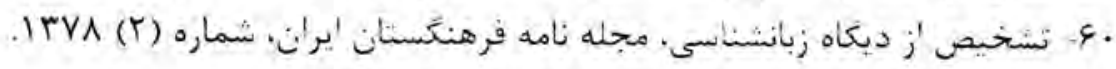

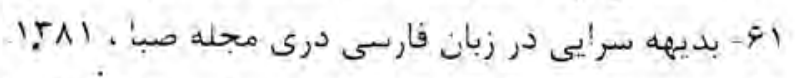

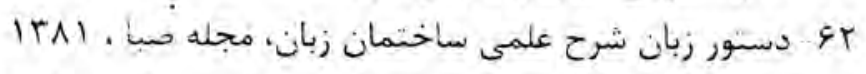

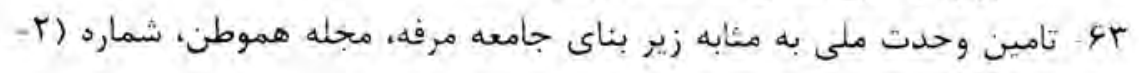
ITA (T

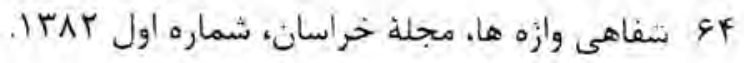

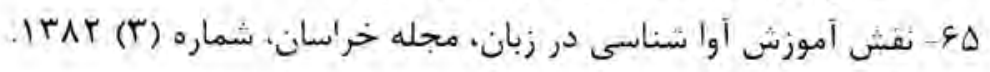


49- برخى 'ز تكات ادبى و زبانى كلام شيخ سعدالدين أنصارى، مجله خر'سان شماره (f)

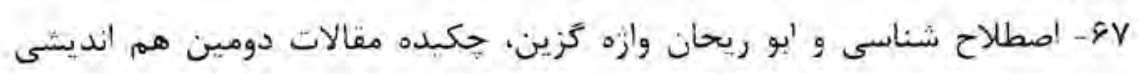

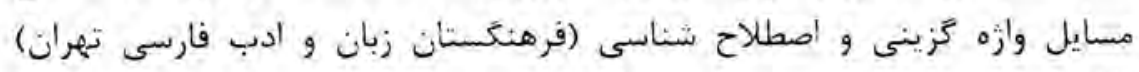
ITAT هو- خوانش مقاله اصطلاح شناسى و ابوريحان وازٔه كزين در سمينار هم انديشى ذكر شده،

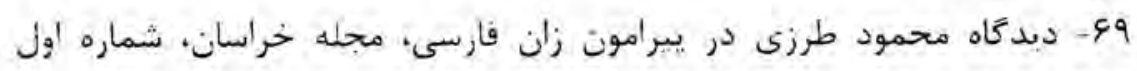
irar

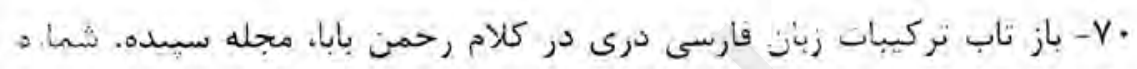
irat (ID-if)

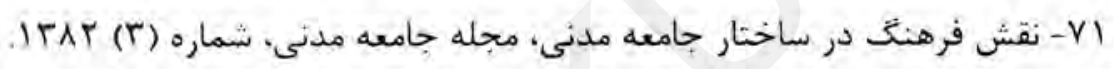

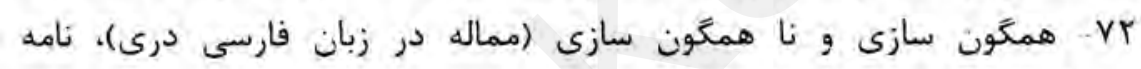

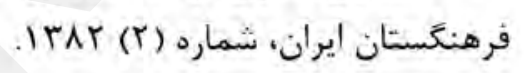

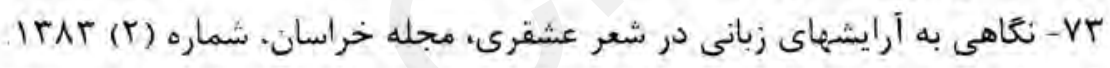

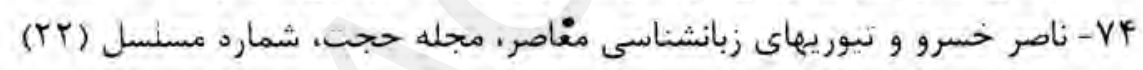
irar

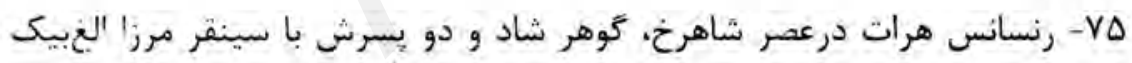

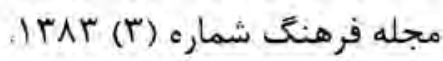

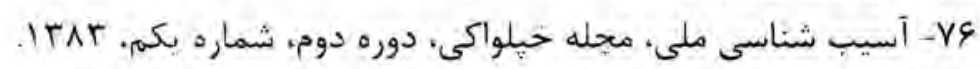

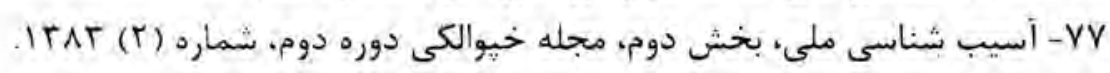
-VA كوشانيان V9 - خوانش مقاله شكوه و جلال كوشّانيان در سمينار بين المللى كونشانيان كابل. irar 


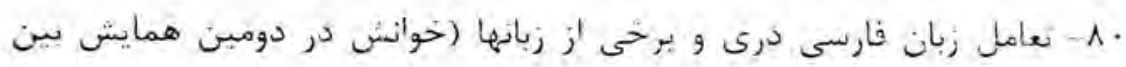

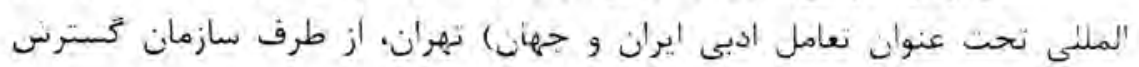

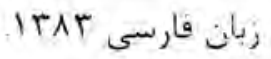

رهنمايى. ارزيابى و ارائه تقريظ بروفيسور دكتور محمد حسين يمين بر كتابهاي و رساله هاي علمى - تحقيقى استادان دانشخاهيها و محققان: مر بوط به استادان دانشعاه كابل:

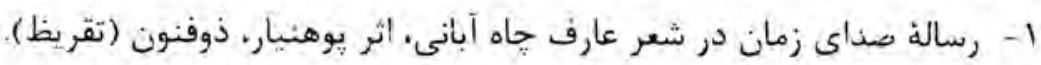

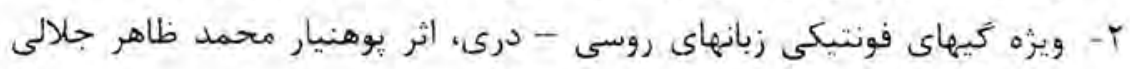
(رهنمايى)

r- رسالة تركيب أسمبه ها در آلمانى و درى، اثر بوهنمل. غلام دستَّير بيبود (رهنمايى) (رسالة

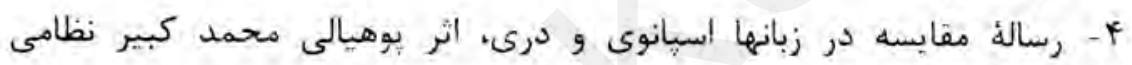

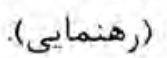

ه- كتاب طنز و فرا ورده هاى زورناليستى. اثر يوهنوال محمد كاظم آهنَ (تقر يظ)

ه- رسالذ فعل إز نعاه زمان و وجه در زبان روسى و درى، اثر بوهيالى خواجه إقا.

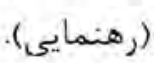

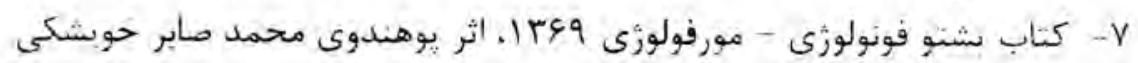

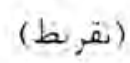

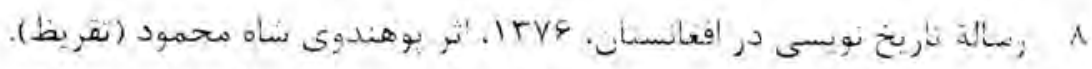

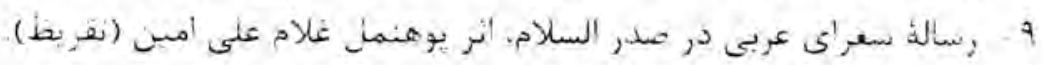

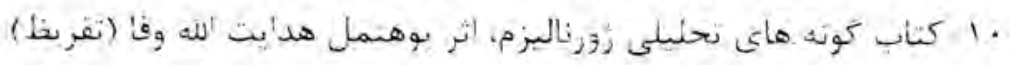

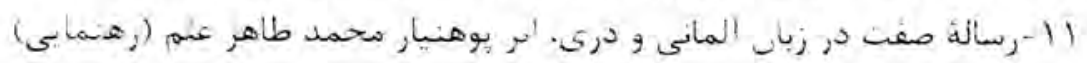

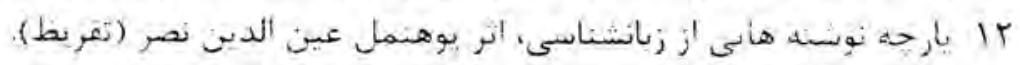

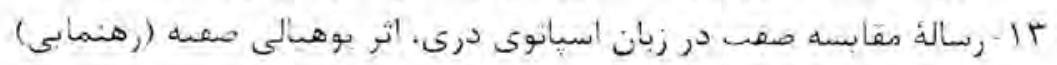




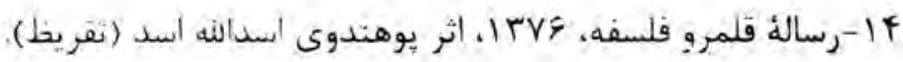

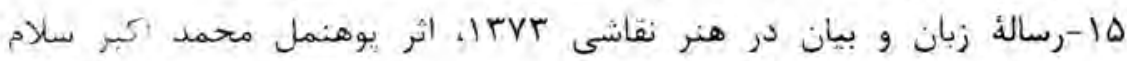
(تقريخا

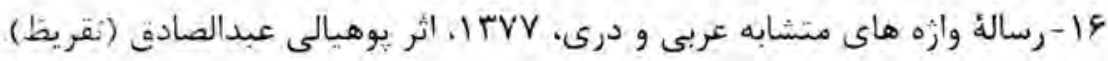

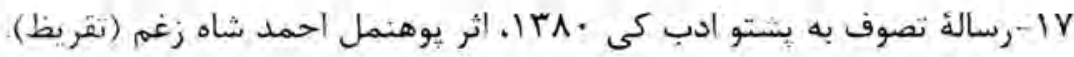

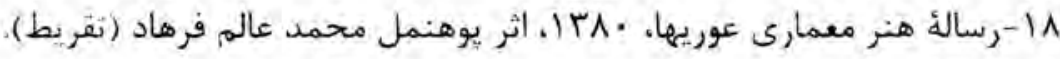

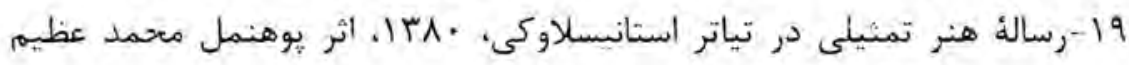
حسينزاده (تقريظ).

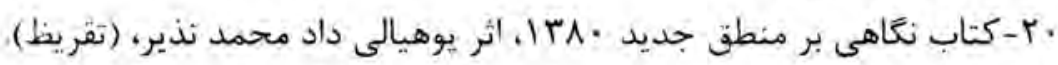

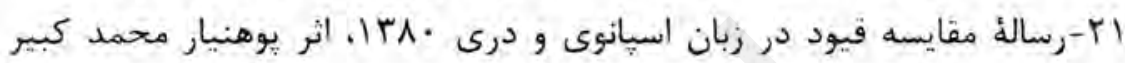
نظامى (رهنمايى)

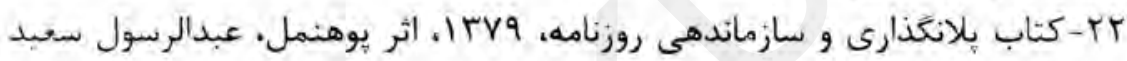
(ثقر يظ)

r T - رسالك مقايسه فعل در زبان اسيانوى درع. اثر يوهنيار صفيه (رهنماني).

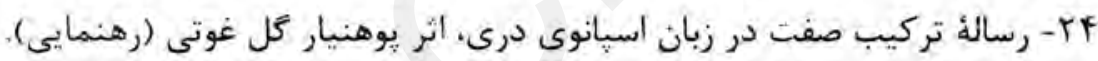

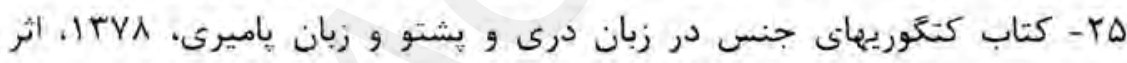
يوهنمل جمعه كل لورين (رهنمايیى)

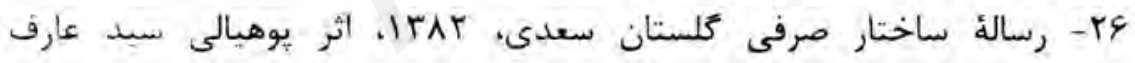
(رهنمايى)

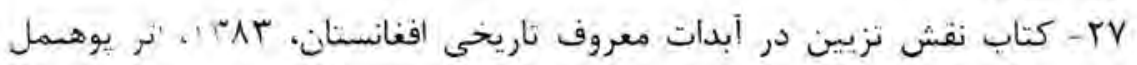
محمد عالم فرهاد (رهنمايى).

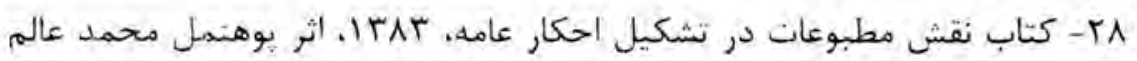
فرهاد (رهنمايى).

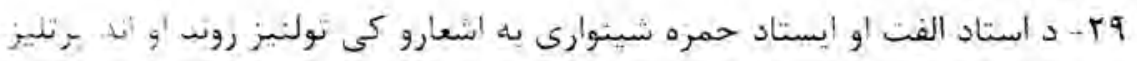

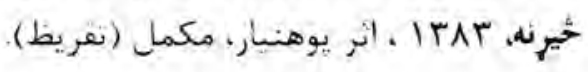




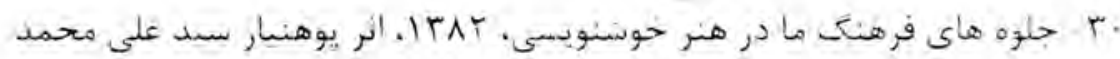

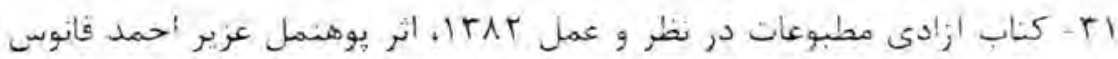

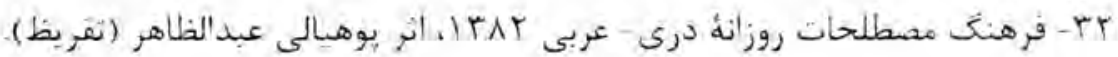

مربوط به استادان يوهنتون تعليم و تربية. ارزيابي، رهنمايى و تقريظ بمين بر

\section{كتابهائ علمى تحقيقى:}

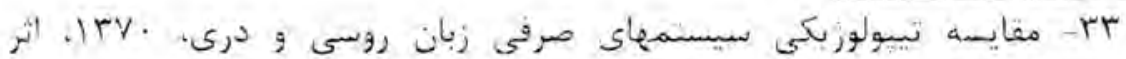

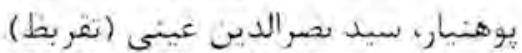

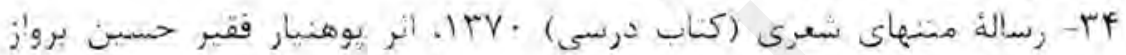
(sis)

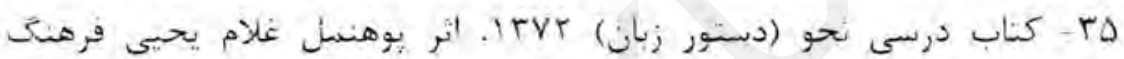

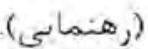

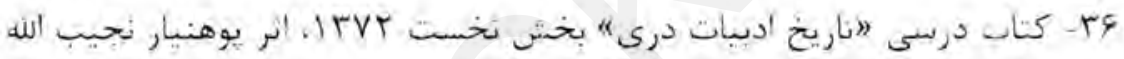
ساسى (رهنمانى)

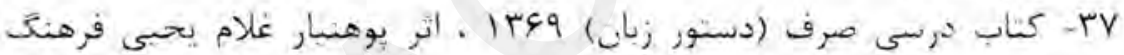

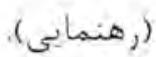

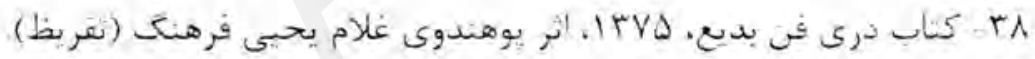

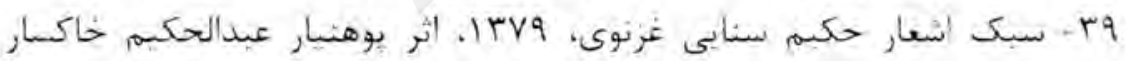
(رهنمابى)

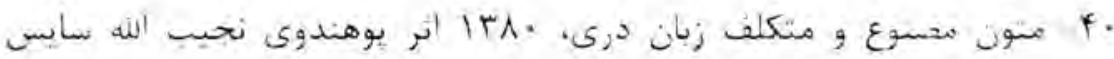
(تقر بط)

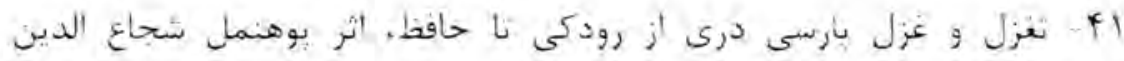
خر أسانى (رهنديى)

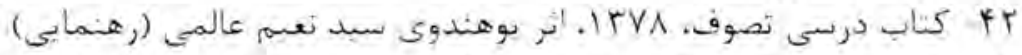

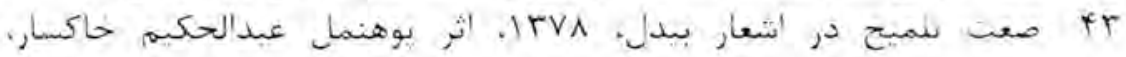
(نقر) 


\section{مربوط اعضاى اكادمى علوم افغانستان، ارزيابي، رهنمايى و تقريظ يمين بر كتابهاي علمي تحقيقي:}

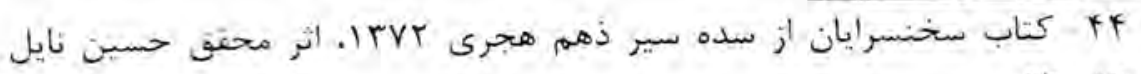
(نقر يظ)

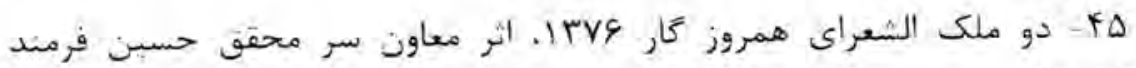
(تقريظ)

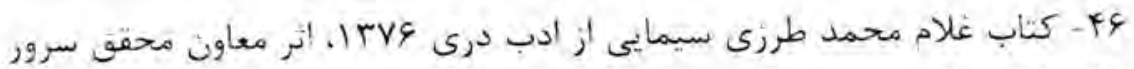
بأكفر (تقريظ)

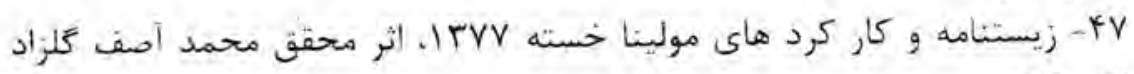
(تقر يظ) ( ) 14 - كلمه هائ مركب در مثون منسور قرن جهارم هجرى، اثر محقق شريف الله

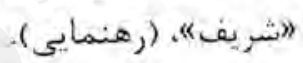

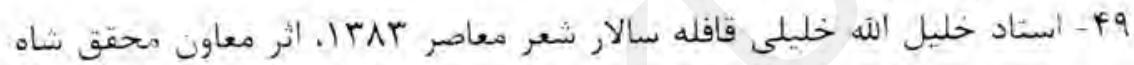
محمد مصلح (رهنمابى).

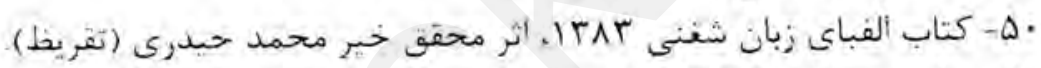

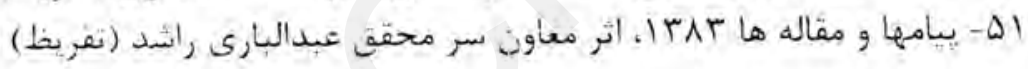

مربوط به استادان دانشكاه بلخ، ارزيابى، رهنمايى و تقريظ يمين بركتابهاي علمى تحقيقى:



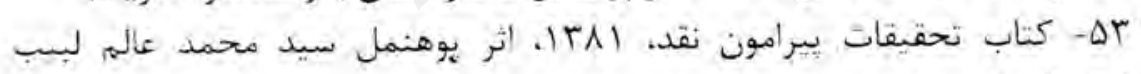

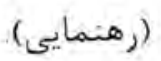

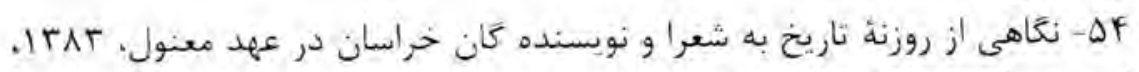

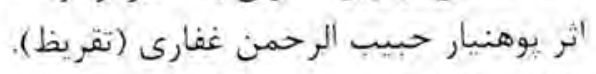

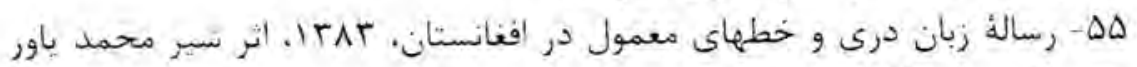

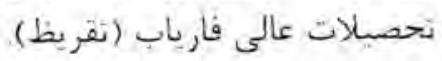


فهرست عناوين

صفهد

الف

ب

飞

1

rq

a.

$\Delta \%$

$\Delta \Lambda$

द,

s'
منوان

علدمد - زيسنامه

آنَار جائى

رهنمايى و ويرايش آثار علمى - نحفبقى

f غليات

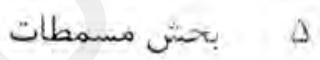

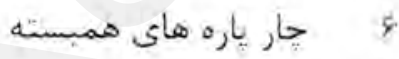

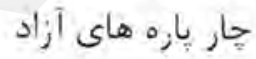

$\mathrm{v}$

1

iो

1. 


\section{بمث غزليات}

\section{مام ميهن سوكوار است اى خدا}

روز روشـن شـام ثار است اي خـدا

اشكهها بـر ديسده بار است ائ خـدا

جنگ و كشتار افتخار است ائ خدا

مملكت ازجهل خوار 'ست ائ خدا

دشمن بى نـخَ و عار است 'ئ خذا

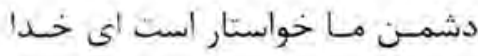

اين مصيبت دل فكار أست إي خدا 'ئ

مـام ميهن سـوكوار استـ أي خدا

علـم و فن بى اعتبار است اي خــد

با مصيبتها دجسار است ائ بـدا

سده هـــــــن نامدار است الى خدا

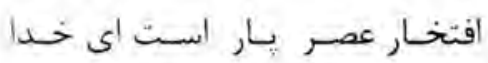

علم و فن ما را به كار است اي خدا لبدا

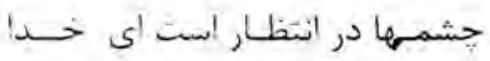

حسال مـا از جنى زار است ائ خدا غرق خون اسث هر دلى در هر كحا صلح خير است اين كجا داند خسى ذلـت مـا از يسى نـادانسى استـ در بـى نابـودى و خـوارى مـــ

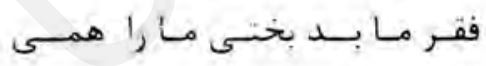
شد نصيسب مـا نفــاق و خود سرى ملى كار ما يكسر بـهـ رسوايسى كشيـد

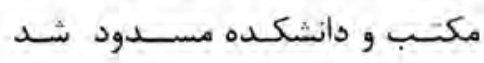
كشـورى كـز علم و فن محروم شد كثــور مـادر علـوم و در فـنــــون دانسش سيسنـا و بيـرونسى مهـ تـاكهـ مجـد بـار را حاصل كنيم. بهـر احيـاى معـــارف در وطـــن

$$
\begin{aligned}
& \text { ريـ مصيبنهياكوران اى "يمين" }
\end{aligned}
$$

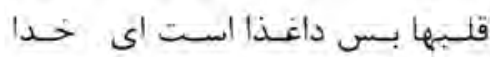

(1) 


\section{بيا كه ميكشد اندوه انتظار مرا}

بهخاك تيره نشاندعشقت اي نمًار مرا

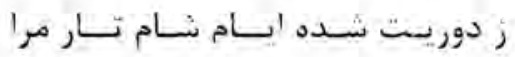

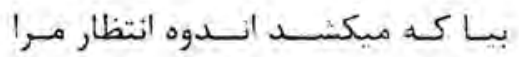

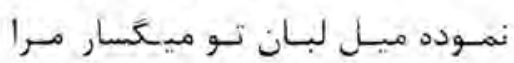

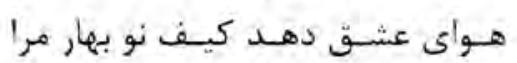

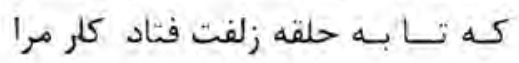

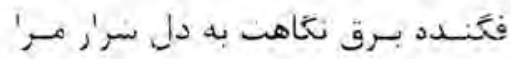

تو رفتى 'ز نظلر از غهم نمى برد خوابه

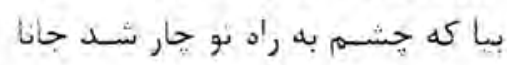

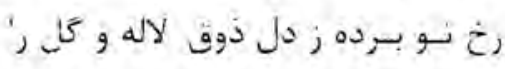
نسمهكوى محبت طرب فز 'أست بهدل

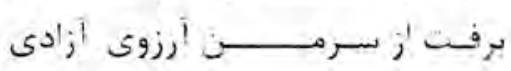

$$
\begin{aligned}
& \text { "يمسن" نسانيى ديكر نخو'هد 'ز تو بنا }
\end{aligned}
$$

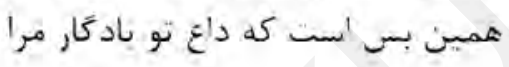

(ITFT)

\section{كار ما هر جاى ظاهر سازى است}

ديمأ أسـدر زيـان هستيـهم مبـا

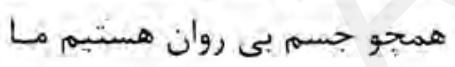

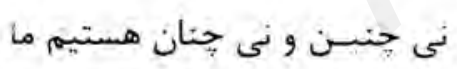

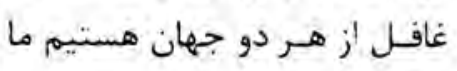

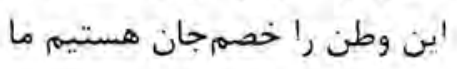

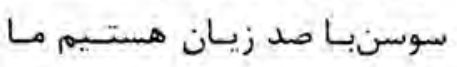

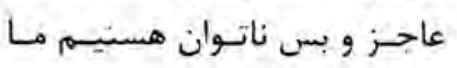

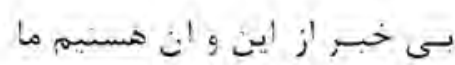

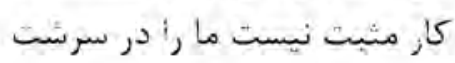

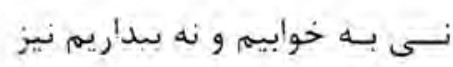

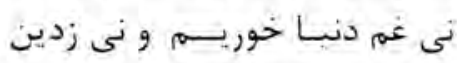

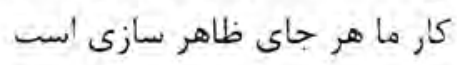

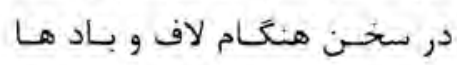

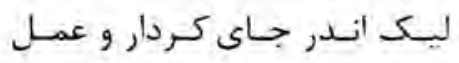

$$
\begin{aligned}
& \text { در مسدار زنده كى هردم "يمين" }
\end{aligned}
$$

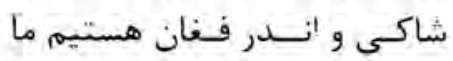

(ITFA) 


\section{آثش عشق}

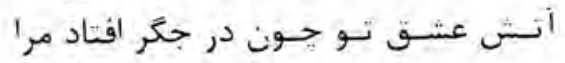

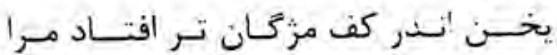

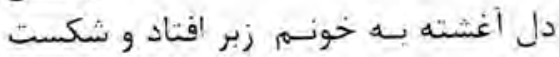

مست جـو دوش بـه كويت كذر افقتاد مر'

$$
\text { سوخم خرمنهستىو شكست ايندل زار }
$$

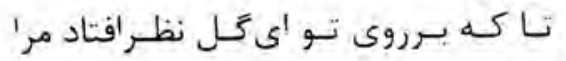

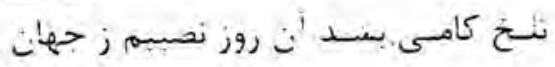

سبرو كارى جو به أن لب شكر أفتاد مر'

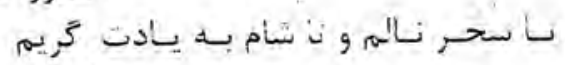

'ى كهمهرت به دل دلشفت بهسر أفتاد مر'

$$
\text { سيشة عشرت من خورد شد 'نخاه كه دل كل }
$$

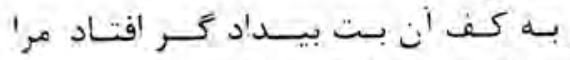

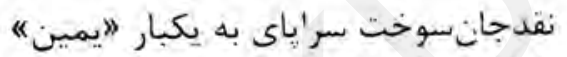

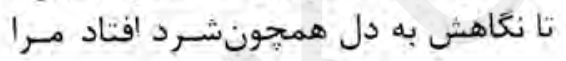

(ITHI)

\section{مقام و منزل عشق إ جمند است}

; آزادى بـرو بـالش بـه بنـد 'سـت

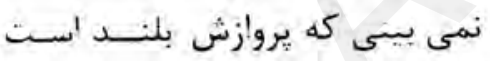

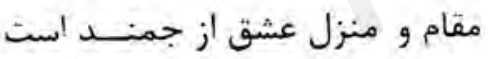

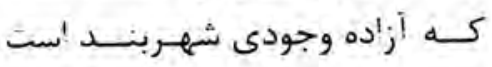

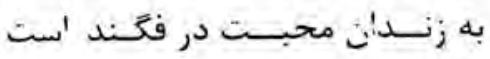

كه دل در طره ات در كيروبند 'ست

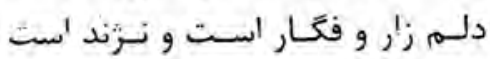

دل عنقــاوشـم انـدر كمنـد 'سـت

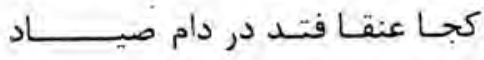

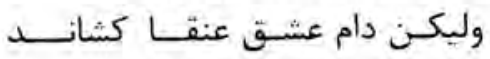
عجايب ظلمه و بيدادى است افسوس عن عنس

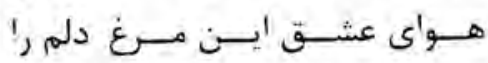

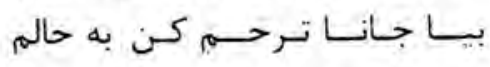

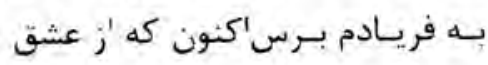

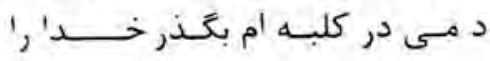

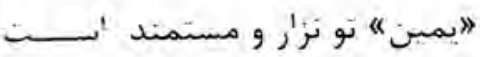

$(1+40)$ 


\section{اينقدر جيفه قييدن خوب نيست.}

ديـدة بسئه دويدث خــوب نيست

اينقدر بيجا جمسدن خوب نسيست

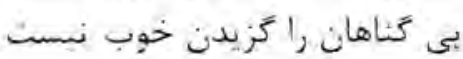

قلب مظلومى در بدن حوب نيست

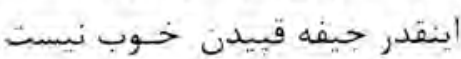

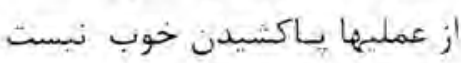

بيس هر ناكس خميدن خوب نيست
'ز حقيقته بـار ميـدن خوب نيست

عاقـب افتى به جــاه ائ بيـخبر

نيش عفـرب وار از كيسن هـر جـا

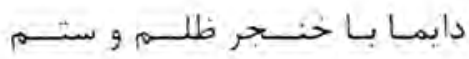

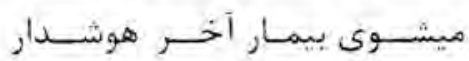

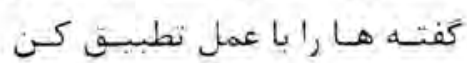

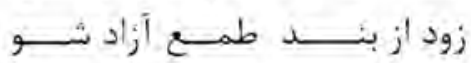

$$
\begin{aligned}
& \text { اي "يمين" هر لحظة در دام سوس برس }
\end{aligned}
$$

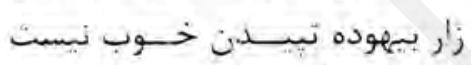

(ITFT)

\section{طفل همجو فو زهال و وكى تازه كالبن الست}

$$
\text { أمروز جشتين عالـى اطفـال ميهـن است }
$$

جشمهمدمبلروى تو اي طفل روشناست

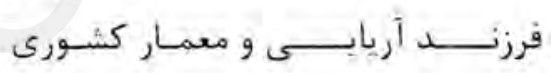

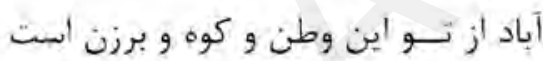

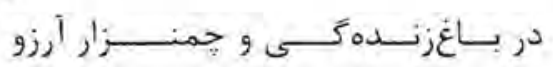

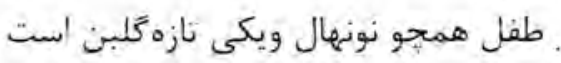

$$
\text { از كودكـان سالــم و شـادان اين وطت }
$$

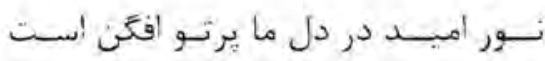

$$
\text { ما عاشقبم بر وطن و كودكسنان خويست }
$$

كلهائ عشق در دل ما در شخفتـن أست

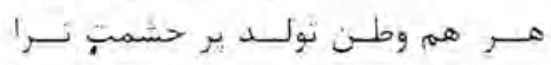

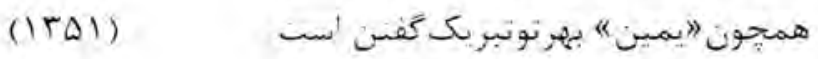




\section{" غزل رودكى وار نيكو بوده}

دمر نخل جون شعر، يــر بار تيست

به هر كس در اين يرده هـا بار نيست

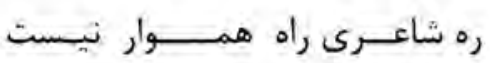

سخن را كه سازىاستيكتار نيست

به جـز دلنــوازي و راكــار نيست

غــزل را هــم استـاد بسيار نيست

جـز او ديـكَىى را ســزاوار نيست

به جسز رودكى هيج سالار نيست

غـزليهاى مـن رودكى وار نيستيت"

عيـان است اين، جاى انكار نيست

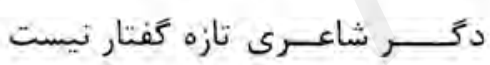

بر اسرار حرفى جهو اشعار نيست

به صد برده معناى شعر انسدر است

بسا هست كـوه وكتـل شعـر را

به سـاز سخن تـا رها همنــواست

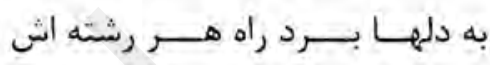

يكى رشته بـاشند سخـــن راغزل

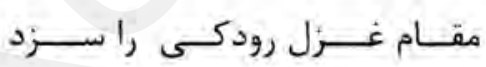

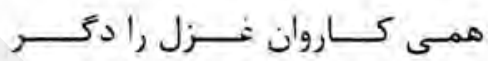

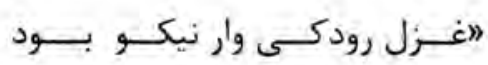

غـزل را كنــد رودكسـى سرورى

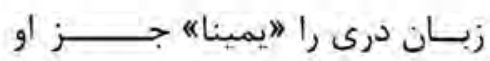

$$
\text { "جنيــن گفتــهـ راكــرده ثابت كند }
$$

(ITVT) 


\section{وقت است وقت}

بهـر كشور اعتـلا وقت است وقت

هرطرفزندست وبا وقت أست وقت

سعى كن همت نما وقت 'ست وقت وقت

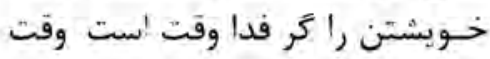

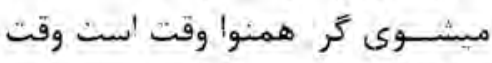

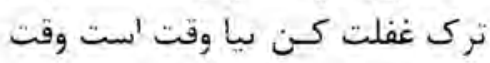

سعى با صدق و صفا وقت ؛ست وقت

مسدمى دل ر' ضياء وقت أست وقت وفت لت وفت
إى كه خواهي ارتقا وقت است وقت جهــد كـن جون رئ راد مردان جهان

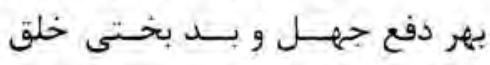

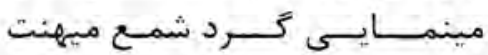

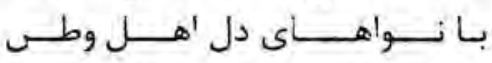
كر كنى خدمت به همنوعان خويش

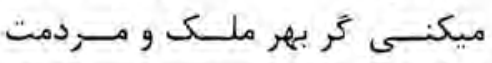

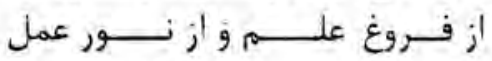

(ITFF)

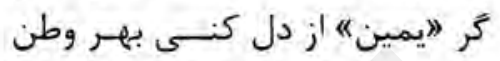

\section{آن دلبر زيبنده رخ آن سيمبر آنجاست}

خـوش باد كه إمشب صنمر لب شكر إينجاست

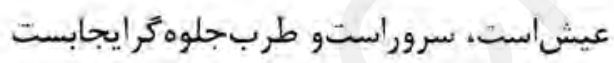

$$
\text { إينهـاست كَلى و سرو دلار إست در 'ينجـا }
$$

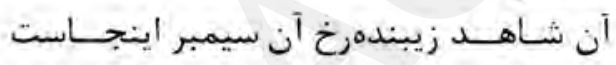

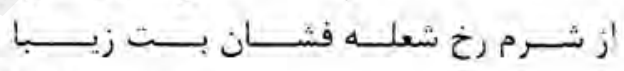

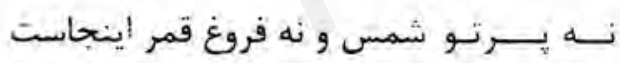

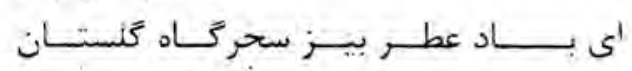

أهسته بــرو هـوش كه آن مو كمر 'ينجاست

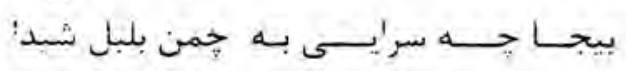

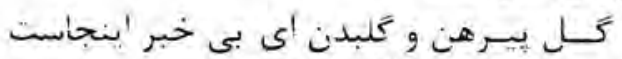

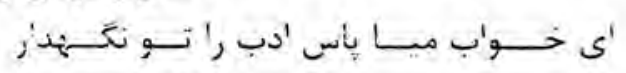

كان نور نضر شب همد شب تا سحر 'ينجانست

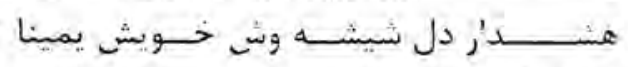

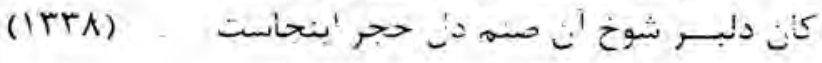




\section{آريانا ميهن نام آوران آسيا}

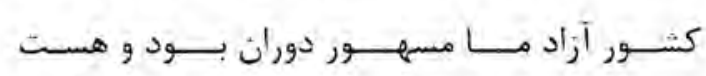

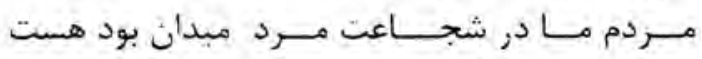

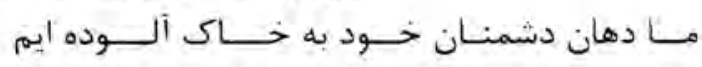

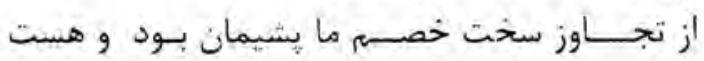

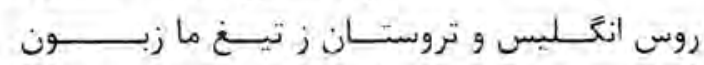

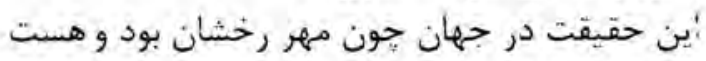

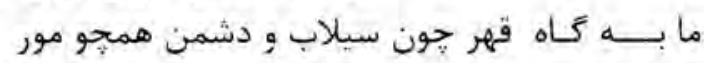

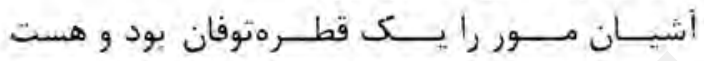

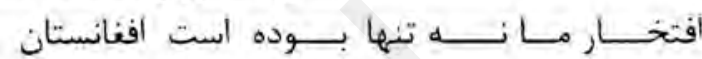

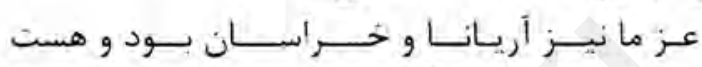

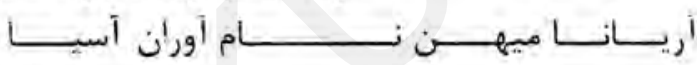

هـــم خــــاسان كشور تـاريخ سـازان بود و وهست

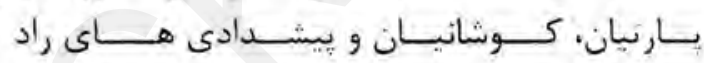

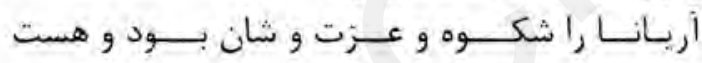

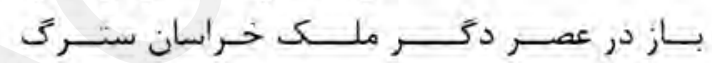

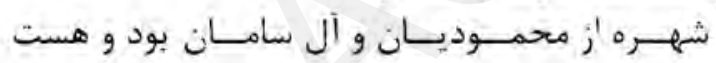

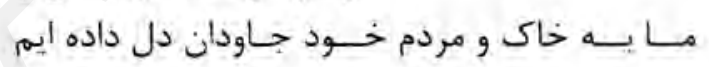

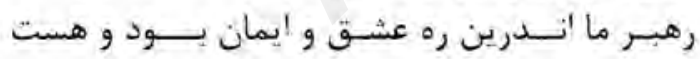

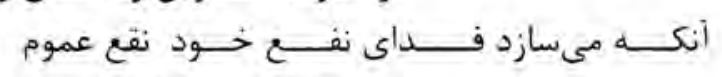

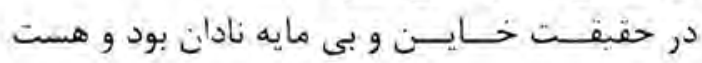

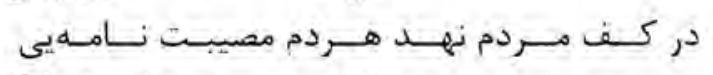

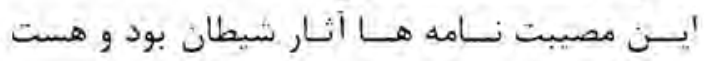

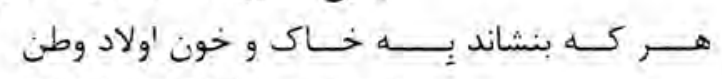

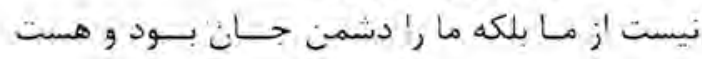

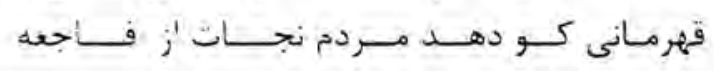

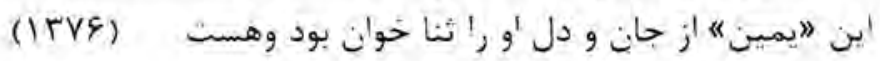




\section{كذشت}

كلارفَّت ووصل يأر كل اندامهم كذشت

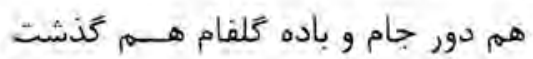

$$
\text { هميارمست و هم منو همروز كارمست }
$$

مستى مــا و مستسى ايام هــم كذشت

$$
\text { تـا بـون دلبرم به بـــر آرام داشت دل }
$$

أرام نل بــرفت و دلارام هــم كذشت

$$
\text { سوداي عشق كُشته دروغىو دل كنون }
$$

أز يار و اين معامله خــام هم كـــشت

$$
\text { يادام جشمه و بسته دهـان از كنار رفت }
$$

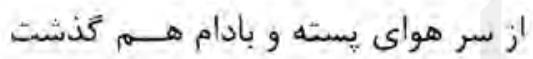

يــار آمـد و سعادت اقبال هم رسيــد

اندوه رفت و بخت بد انجأم هم كذشت

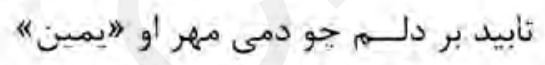

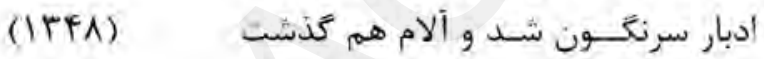

\section{ثن هيج}

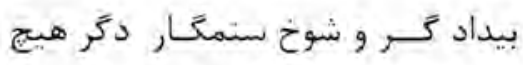

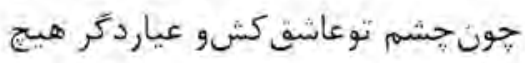

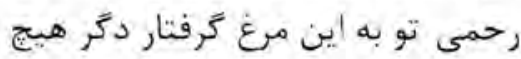

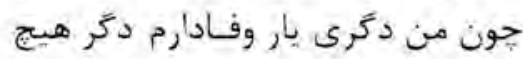

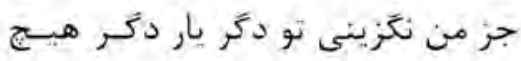

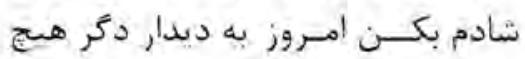

جـــون تـونو نبود يار دل آزار دمكر هيج ديديم بسى حشمه و نديديم در منشهر

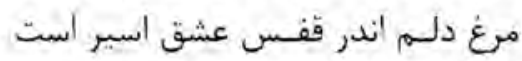

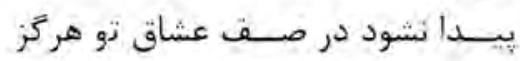
خواهم كنوفايشيشه كنى إى دل و و جانم

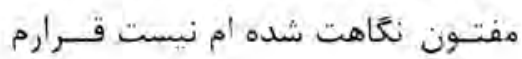

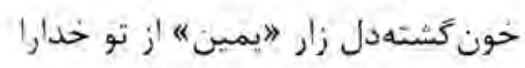

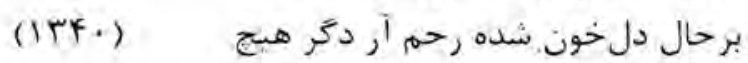


آزادى

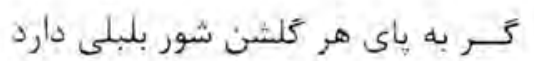

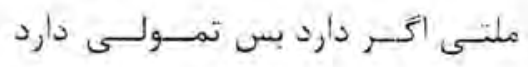

همجِـــو بلبل شيــاشورو غلنلـى دارد

كاخ عزت و شانش كى تـزلزلى دارد

عسكر شأتر همجون شيروشدلى دارد.

در مصساف الحر بينى نشتئة ملى قارد

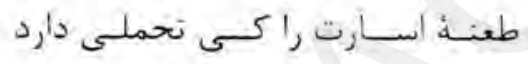

يا سعادت هستى خوش تسلسلى دارد
كَل زمين أزادى خـوس تجملى دارد سوز و شوق آزادى روح حريت خواعى نسي

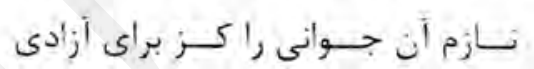
ملنى كهة أزاد است ارتقاء نصيبش شد

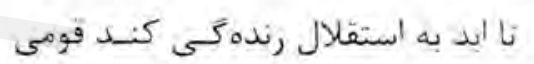
بهر عسكر ميهن خون دشمن خاكث در صيانت خاكش بكذرد زحسان خـود هر كحا به هر كشور اين هماى أزادى دي

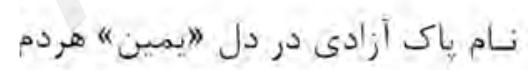

كلمسن نلـي دارد جوش سنبلى دارد

(ITFS)

9 


\section{جاه و جلال اكر دهدت هم هنر دهد}

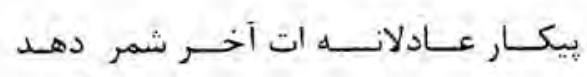

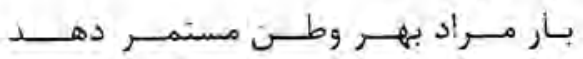

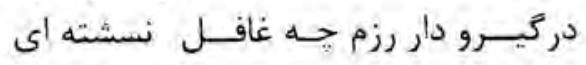

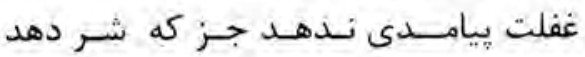

دشمن اكر قوى است ترا دل قوى ثر است

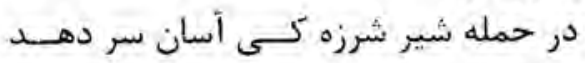

با دانش ار شجـاعت و همت شود قريسن

خوشبختى است حاصل آن دست اكر دهد

$$
\text { جـام سعادتـى كنــــد ار دانشت نصيـبـ }
$$

غيسـرت همبى بـهـ دست تو جام دكر دهد

جايى براى بى هنــان نيسـت در جهـان

جـاه و جـلال اتى دهدت هـم هنر دهد

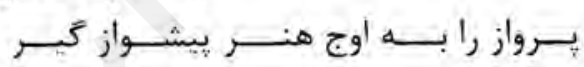

عــزمت در ابسـن ميـانه ثرا بال و ير دهد

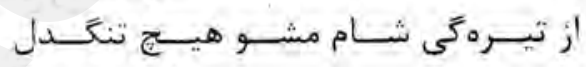

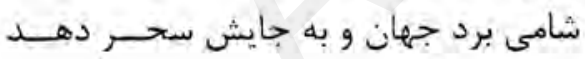

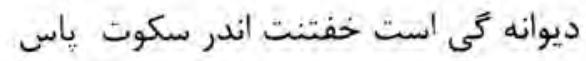

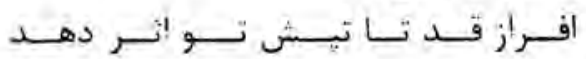

هــــــــاده دل نه لايق عز است و افتخار

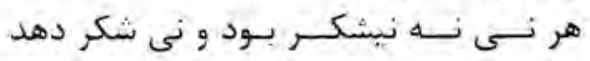

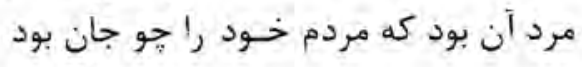

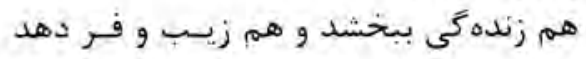

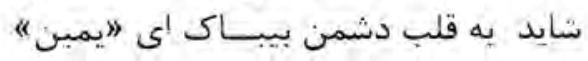

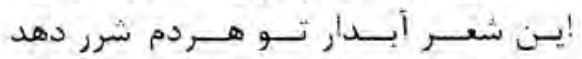

(IrD.) 


\section{دل عل عاشقان شيداجه دل فكار باشد}

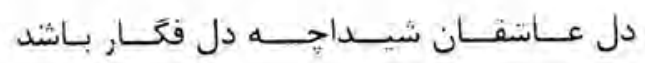

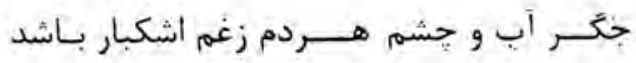

حه خوش است عائقى رأكه به بورمه به كَّن

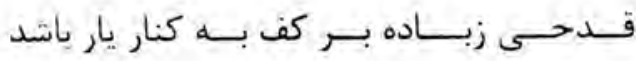

$$
\text { مسـه من بيــا كه اين دل به دل شب از فراقت }
$$

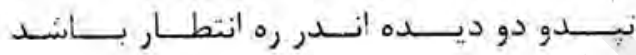

$$
\text { شب عساشق از جمـال تـو بود جو روز روشن }
$$

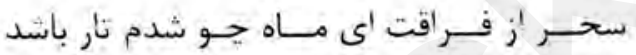

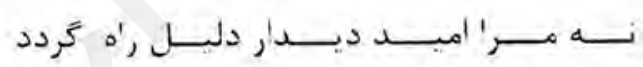

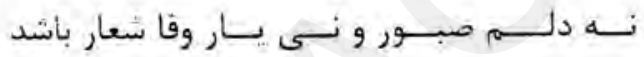

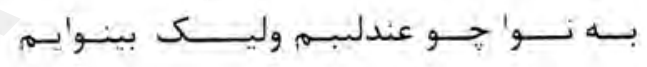

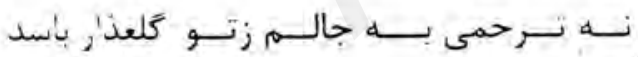

$$
\text { بـهـ فـدايث 'ي دلا ر' دل و جان خويش سازم }
$$

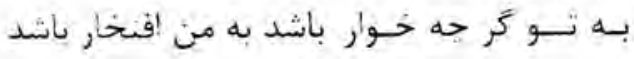

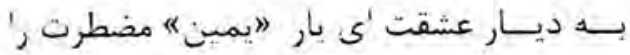

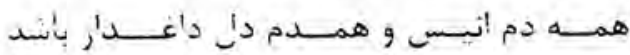

(ITTA) 
خويش را در دلبرى مشهور كرد

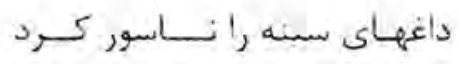

صبــرو آرام أز دل من دور كــرد

خويش را بردار حون منصور كرد

خوشش رأ در دلبرى مشيهـور كرد

دل هم إين مقصود را منظور كرد

رفت و روى خود زما مستور, كرد
نر بنس حسمش مسرا محمور كرد

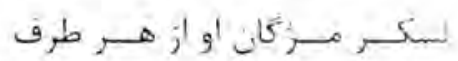

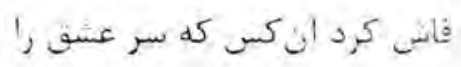

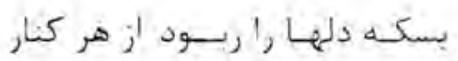

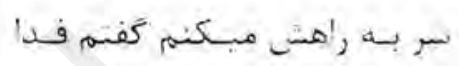

دلبر من أز حه رو بـى ههر شـد

مبتـلاع درد هجـر أسـم "دميني"

درد هحرانشي مرا رنجهـور كـرد

(Irfi)

ir 


\section{اكر بسوخت جهانى سخن نمىسوزند}

دلست بـه اين وطن اي هموطن نمىسوزد

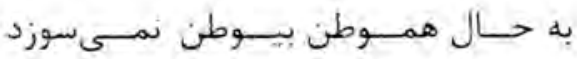

خــراب كشـت وطــن همـوطن شد آواره

دلت كه هست! جرا زين محسى نمئسوزد

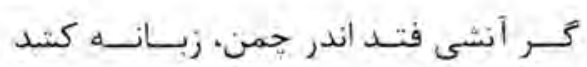

عجب آح كل و سـرو و سمن نمىسوزد

فتـاد در جمنستسان مييهــن آتش كيــن

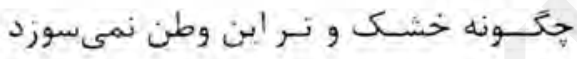

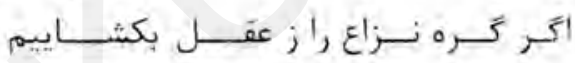

در تـو، مـال وى و سقـف من نمىسوزي

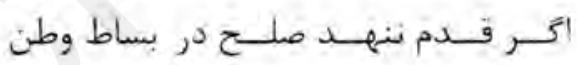

جـــــاغ بخـت در ايسـن انجمن نمىسوزد

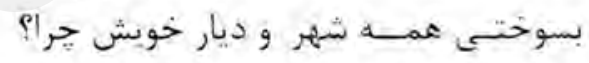

دلــت بــهـ ايسن همه آتش زدن نميى ستوزد

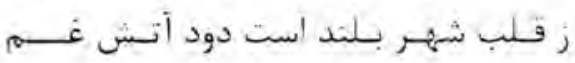

كـــدام دل كـهـ از إين سوختن تمىسوزت

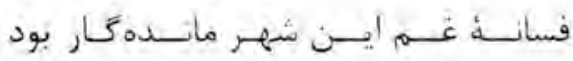

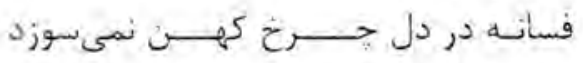

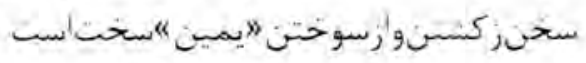

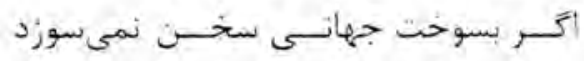

(ITVY) 


\section{خاطره در تضمين يك فرد ملك الشعرا بيتاب}

در سال وبr ا خورشيدى كه بنده محصل دانشكده زبان و إدبيات بودم روزى من در

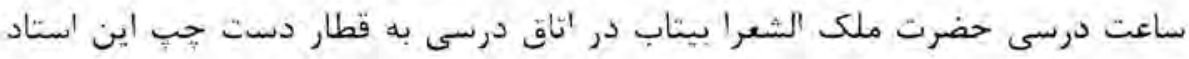

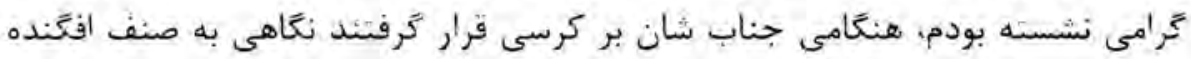
الشاره كنان به جانب بنده كفتند: "يمين ما كله به حيب در كنار بنشسيد

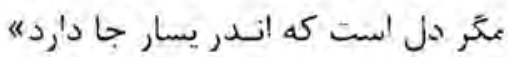

هن دو روز بعد قطعه شعر زير راكه بيث منذكره در آن تصمين شذه است حضور شان

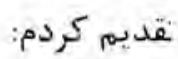

زدانس هـر كهم يكى قلب با صفـا دارد

يفبن بود كه به كف شمع اعتـلاف دارد

همبشه صاحب دانش به ملت و به وطن

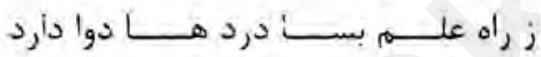

بـراى جـامعه روح است عالمى وفـاضل

جو رهبرىاست كه در كف جراغها دارد

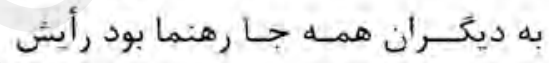

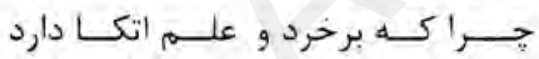

بسه هـــر كجاى همى احترام مشكردد

به هر طرف كه رود حا به ديده ها دارد

به دفع منكلل احباب شخص دانشمند

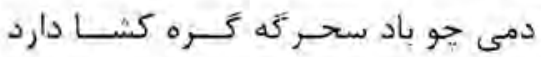

ثمى شــوند فـرامـوش فاضــلان هركّز

همبشه شهرت شأن در حهان بقا دارد

$$
\text { ; عـالمان بـود هـر ملتى كث بـ بهره }
$$

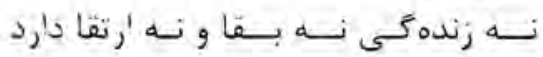


.

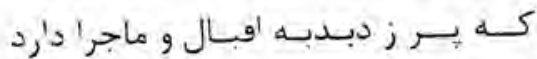

بسـ رجـال خــردمند و صاحب دانش

بسا اديب سخـن سنج و خوش إدا دأرد

ميان آن همه شخصبتى كه ممثاز است

كسى كـهـ زان همه بس فكرت رسا دارد

بــود يختـانذ أفــاق حضــرت بينـاب

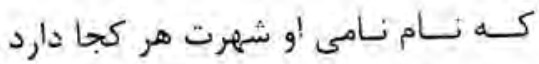

جو'ن طبـع و رسا فـكر و نكته سنج بود

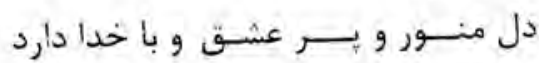

اديبو فاضلو دانا است آنجنان كسامروز

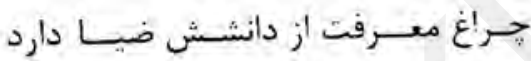

بـهة ملــك شعر بـود رِادشاه روشندل

به كــف ز آكـيهى جـام جهان نما دارد

تكـــو 'دا بـود و بيـك خوى و نيك نظر

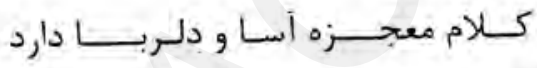

جنـاب بيتـاب كز حد فزون عمرش باد

برون ز حسـد همسه شـاكـرد با وفا دارد

زجملههبت بكى هم "يمين" هيحمدلن

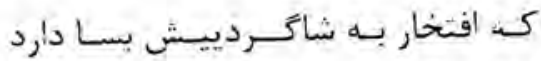

بهعلمصاحب دست قوى است اين 'ستاد

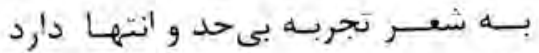

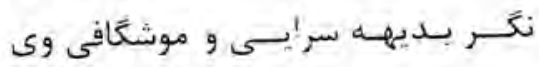

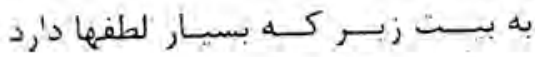

$$
\begin{aligned}
& \text { "ايميسن ما كله به جي در كنأر بششسنه }
\end{aligned}
$$

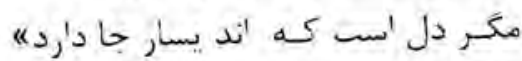




\section{آه غريب و اشك يتيم}

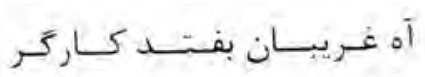

أه شـرر بــــار دل شعـله ور

همجو در آتش كه فيد حوب تر

نرمشَود دل، دل همحون حجر

اى كسه تويسى دُانشى و با هنّ

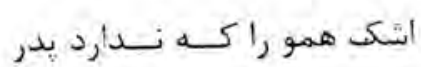

اشكك يتيم است به سان كَهر

دست نكَهـهـدار كـه دارد خطر

بى سرو سـاماتـه و زبـــرو زبر

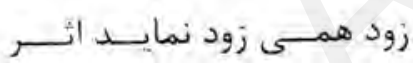

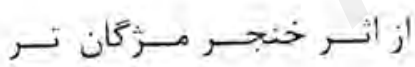

سخت و دل افكار ولى بي خبر
مر دل شبهـا و بـه وقت سحر

آتس سبوزان بـه جهان افغند

قلب شود در تَش از حرقهاش

خلــق بسوزد ز سرارتى همى

هوسَ مسريزانَ و مكـن مإيمال

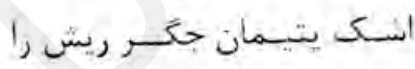

نيك همى دان تو اين نكته رأر

هوش نمـا هـوش زتسوفـان او

ورنـــه شـود دهر ز سيلاب آن

آه غـريب اشتـك يَّبمـان زار

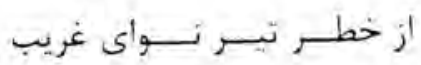

كن حذر اي جان كم آيد بهتو

$$
\begin{aligned}
& \text { الحذر از آه غـريب اي "يمبن" } \\
& \text { الحذر از أشــك يتيّم الحـذر }
\end{aligned}
$$

(ITFT) 


\section{كار بايد بنمود از همه بسيار امروز}

شتــاد باش اي وطن أى مأمي احرار امرور

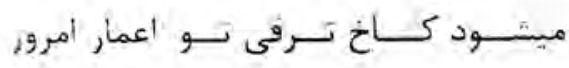

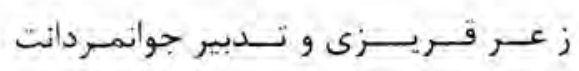

نَكـرم هر ســوز يبــروزيت آثـــار امروز

در جبسين همــه ابنـــاى وطــن مى بينهم

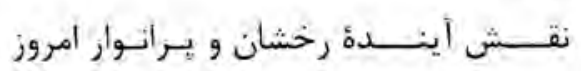

$$
\text { شنــوم زمـزمف كـار زهـر خورد و بزرى }
$$

نهضتـى در دل تـو عشئه يـديـار امروز

فكــــر اولاد تــو بشكست طلســم دشمن

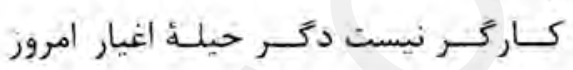

خصسمر رازين تِش و نهضت ما هر نفسى

ميسـرود در جكــــ نيشتـر خــار امروز

جه خوثي استا ينكهبشديبر جوانر اهمدست

حهذخوشاستاينكهبودمردورن همكارامروز

خود بقرما كه ير از نفع ديكر حيست به ما

به حز أز يـك دل و يك ديـده ببدار امروز 


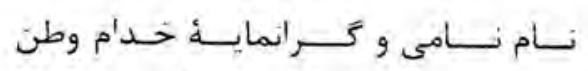

كـر به زر تبت شـود هست سزاوز 'مسروز

$$
\text { بيهر مـاك بنتسر 'ر هـر جهه ضرورت باشد }
$$

مــرد روسنــدل و يركار و وفـــاد'ر 'مروز

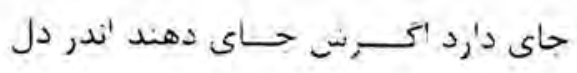

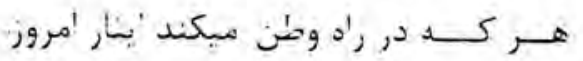

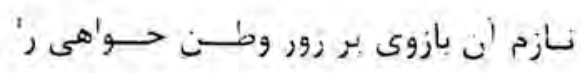

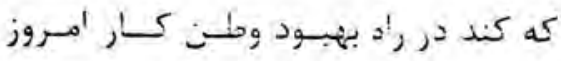

ديـــه تــــ روشن و تا دست سلامت باشد

كار بايســـد بنمــود 'ز همــه بسيـار 'مرور

$$
\text { نا كه كردد دل اين كـوه و كمرهــــــاره }
$$

تـا كـه كلزار شود !ين همه كهبار 'مــروز

تـاكه برغير سُود بيشتر از بيش "يمين"

جوهــــر ذاتـــى ايــن قوم نمودار امرور 
دروغ

سده هر ساده دلى سخت حريدار دروغ

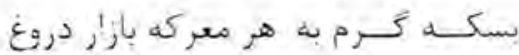

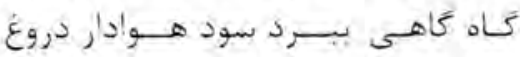
كر حه كرديده جمبان عثلى مدار أما باز

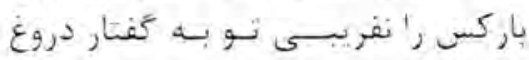

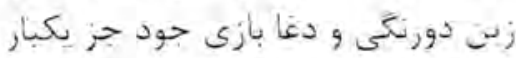

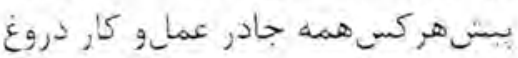

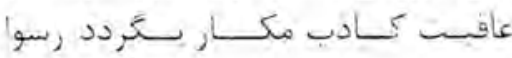

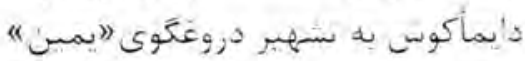

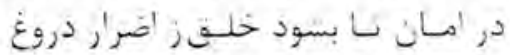

اى اغنيا نكربد حال بينوايان را

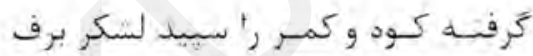

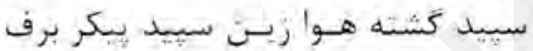

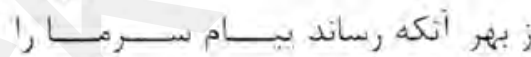
كشـود بــال و به برواز شد كبوتر برف

كثون تصام جهان

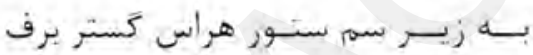

بـرهنه شاخخ درختــان بـاغ أز سردى سبيـــدوار بلـــرزد همسى به مجمر برف

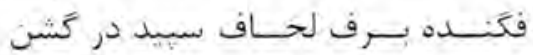

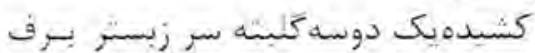

زمبي زهيبث سرماى سخت 3ى اكنون

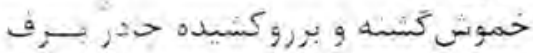

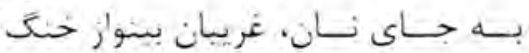

حـورند بر دل و تى تيرها و ختحر برف

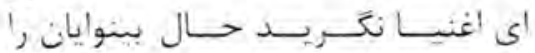

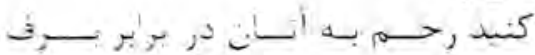

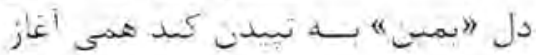

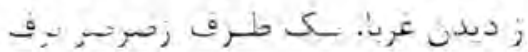

19 


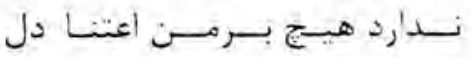

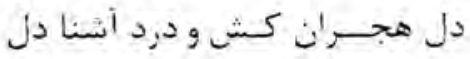

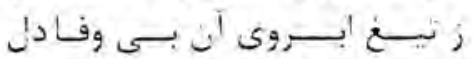

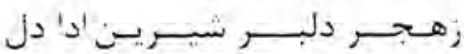

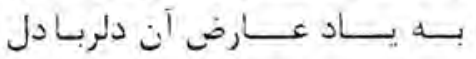

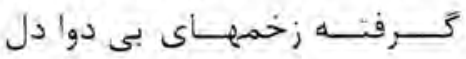

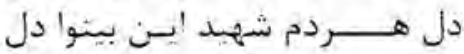

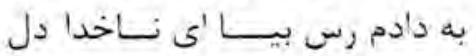

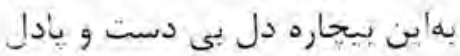

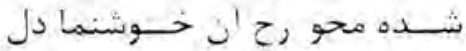
كنون جندى انست انز ما دل حل كرفيته

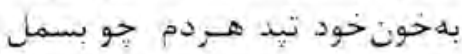

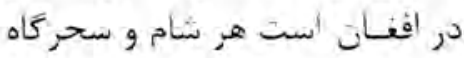

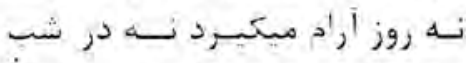

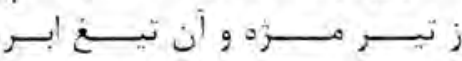

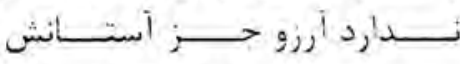

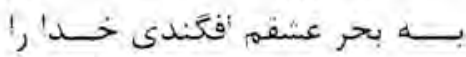

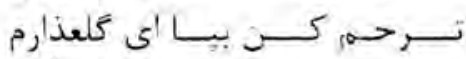

خــــــ اين يمين إز درد هجران

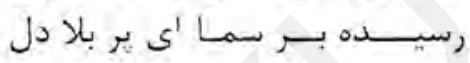

\section{اشكباريهاى دل}

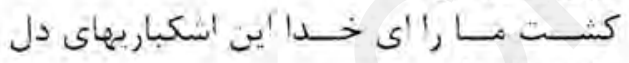

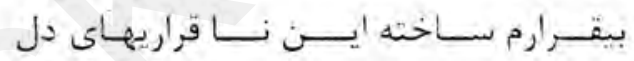

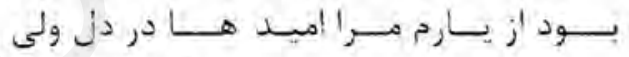

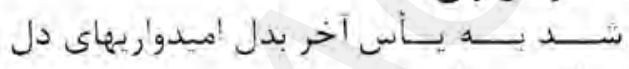

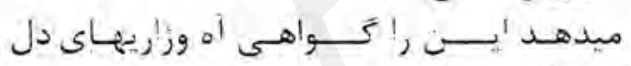

ذاغنها دارم به دل از وضـع

$$
\text { هر شبى را همجو بسمل در تبش سازد سحر }
$$

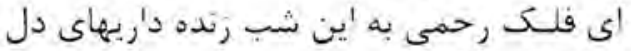

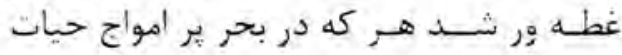

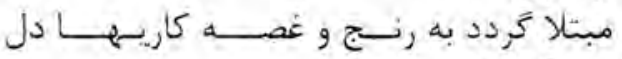

بـا همه بسى دست و يايى ها كشد كوهبا عهم

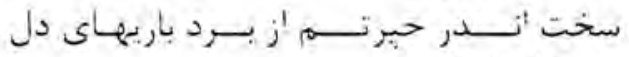

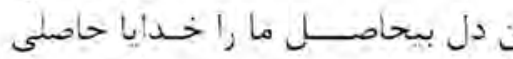

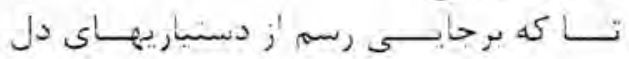

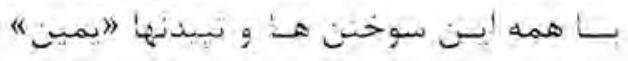

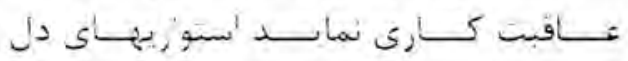




\section{عهد ها استوار ميخواهم}

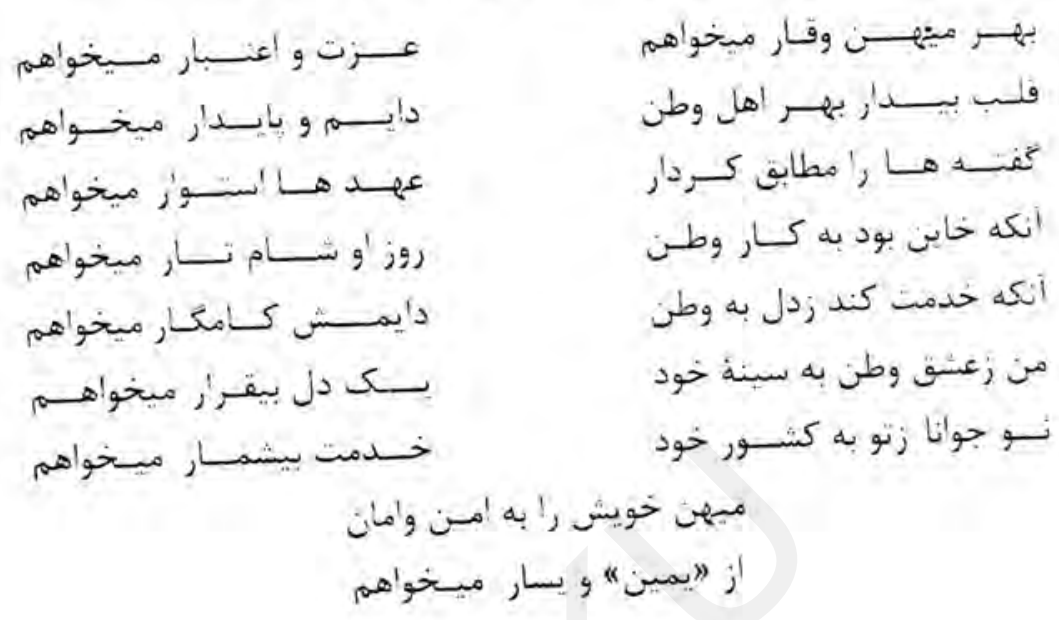

\section{ز اخلاص عشق جانان ميير ستم}

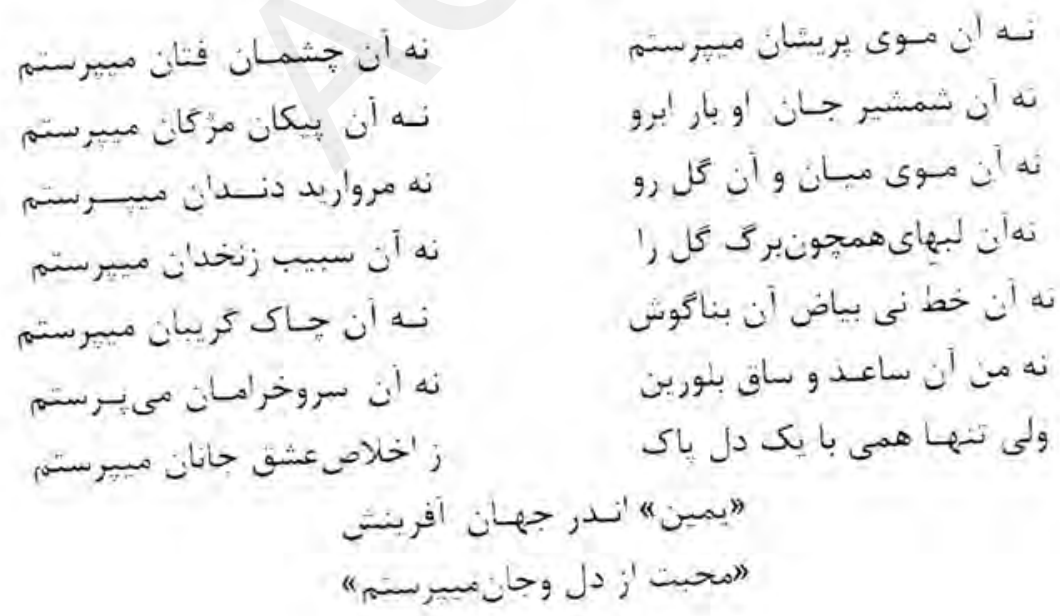




\section{سخنت موميا است ميدانم}

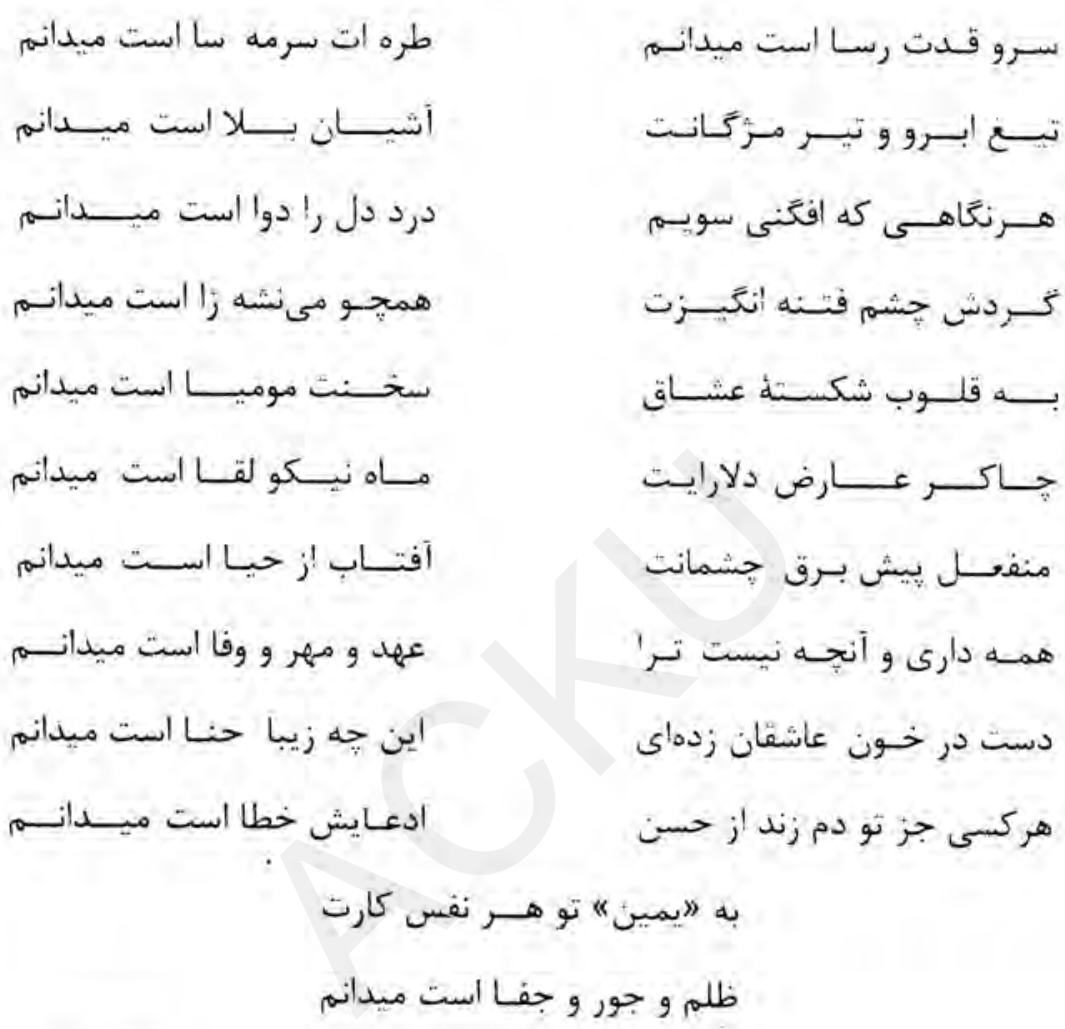

(IFFq) 


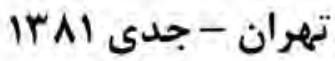

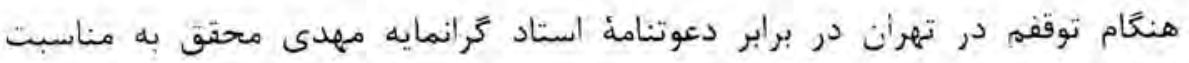

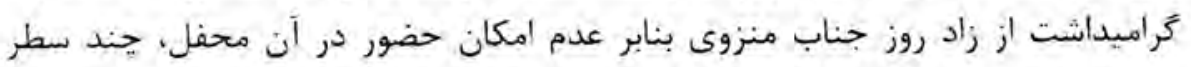

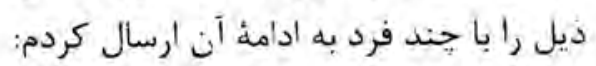

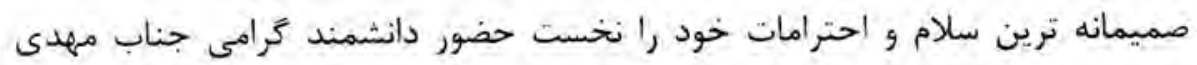

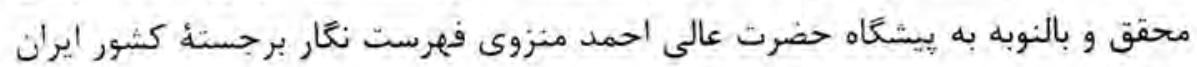

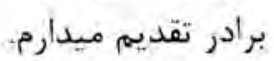
من كه متأسفانه از حضور مر مجفل شكوهمند نجليل از هشتاد مين سال از عمر ير بار

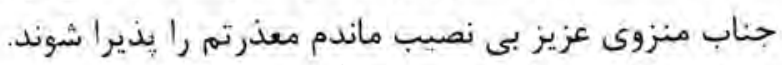

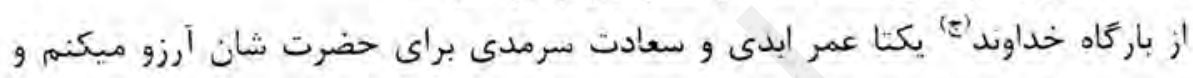

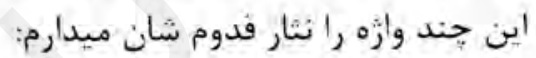

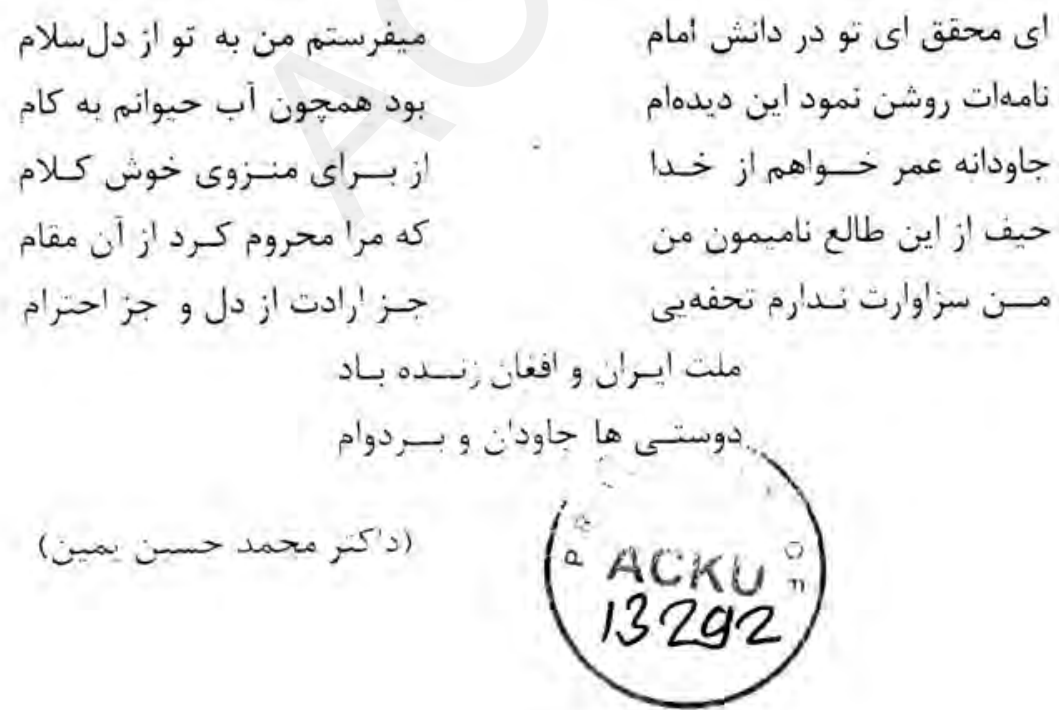

rr 


\section{داشتم دارم}

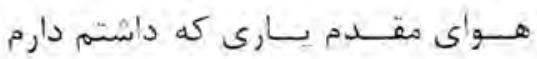

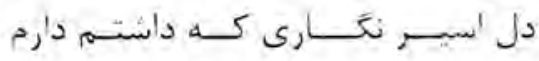

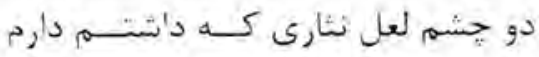

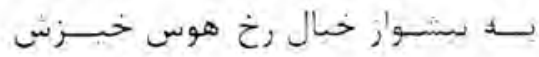

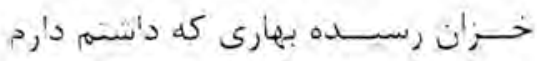

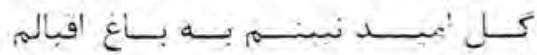

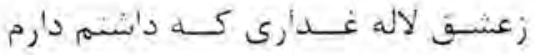

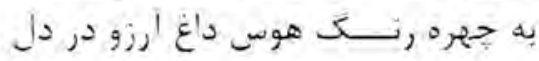

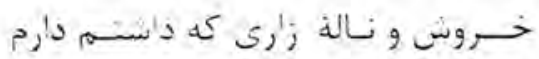

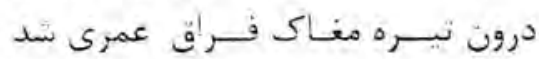

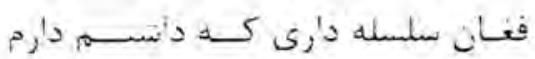

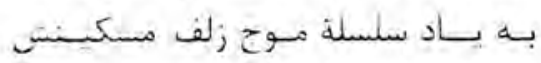

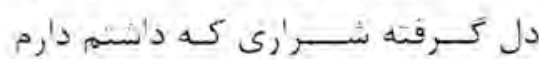
زبك نكاه زد آنش به قلب زار ليمينه

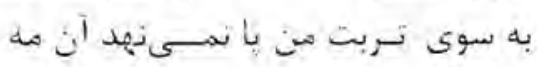

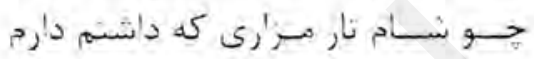

(1ro)

\section{حق بجوييم و حق اظهار كنيم}

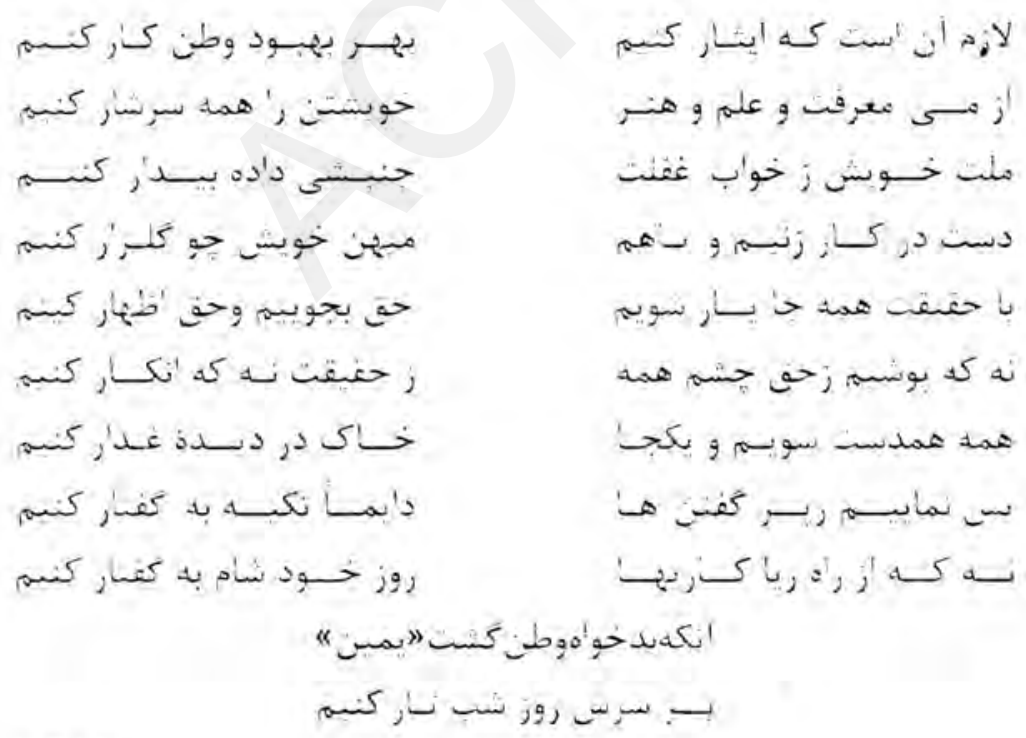

$(1+2 \Delta)$ 


\section{ارغوان}

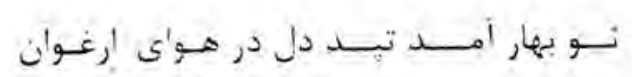

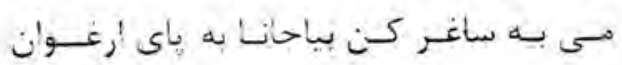

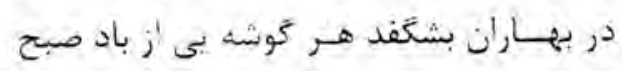

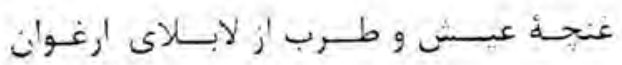

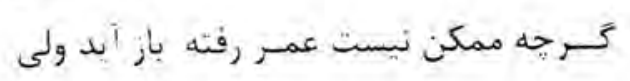

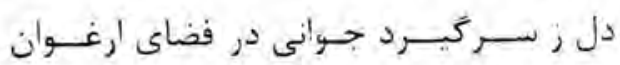

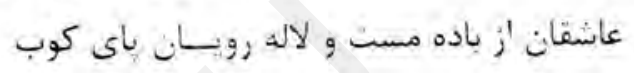

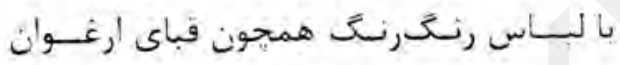

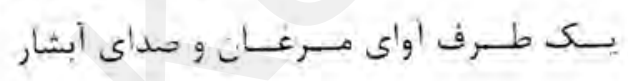

يكك سو رقص لاله ها و خوشه هاى ارغوان

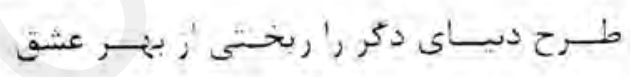

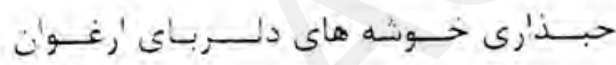

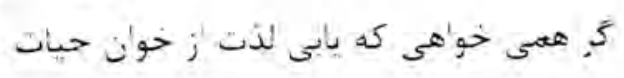

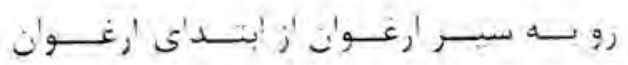

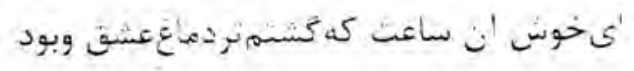

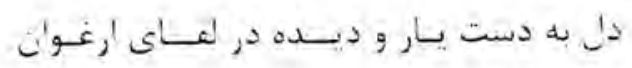

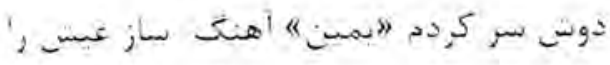

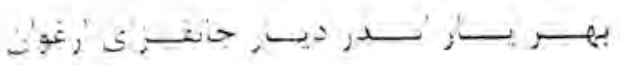




\section{به استقبال يك خورشيدى تابان}

خزان أمسـد بهاران يـافت بإيان نه كـار مملكت را سارز و بسامان

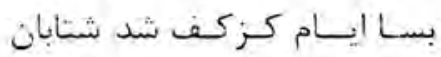

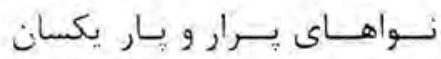

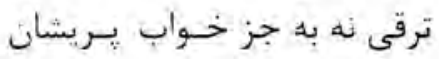

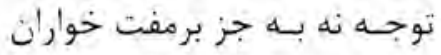
بروروه ذه به جز يعما كرى خوان نبوده هيج الامكسر و وستسان

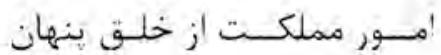
بنساى عمسر مــا كردرند ويران كه خو' بأنند ملت را بـ بــد انسان

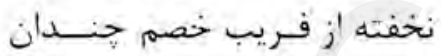

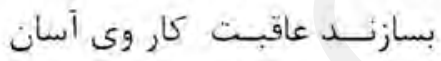
قبام مردمى خون رعد و وتوفان قيام رئج سوز و فرحست افتسان

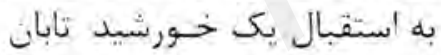

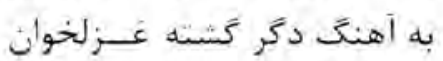

زمستــان رفت و بأز آمف بهاران

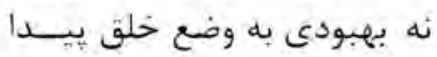

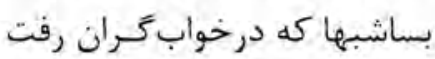

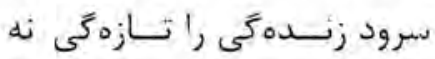
تحسـول نــه به جز اندر سخنها تلاشيىنه به جز در رشوه خوارى

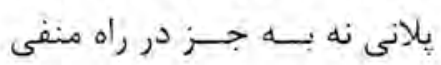

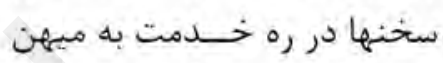

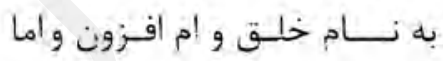
بساط عشرت خود خـوب جيدند

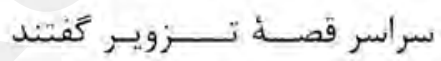
ولىى اين مردم دل زنده هـــرگز

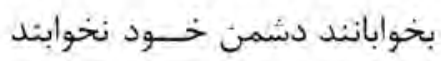
سرشب خواب و نيمى شب فيامى قيام شب زداي و صبسح بخشاى

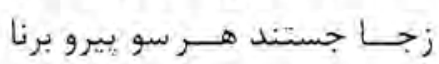

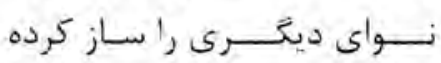

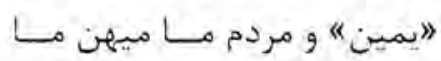

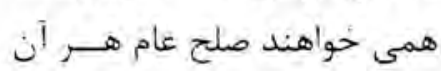

(· اشب f سنله ror برود كاست أز طريق راديو كابل) 


\section{كابلستان}

خـــوشا شهــر و ديار كابلستان

صفــاى مرغـــزار كابــلستبان

بـه هر كنج و كنار كابـلستان

ديسـار و كمهسـار كأبلستئان

كنــــون بينسـم بهار كابلستان

بــواى جــويبـار كابـلستَان

ز زيــــلالـــه زار كابـلستنان

كل يـر افتخــار كابـلمسنان

برايسـد مــرد كـار كابـلستان

دو دست بــر كـار كابلستّان

بــه خلق نامـــدار كابـــلستان

سعـادت ممكثـار كابـلستان
خــوشا ايـن نو بهار كابلستان

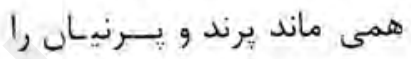

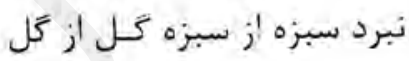
طراوت ميدهــد امروز بر دل بهـار بلخ و نتخكرهــار ديسـدم به دلها ذوق و حال آرد بديدار من اكنون شادم ومىبالم هردم شدهاين شهر كابل جونعروسى در اين نوروز فرخنده به صحرا سعادت بخت مسآرد به مردم مبــاركبــــــاد نــــوروز دلارا خــوشى كابليان جـــاودان باد

$$
\begin{aligned}
& \text { "يمين"خواهد كةهرئوروزوهر روز }
\end{aligned}
$$

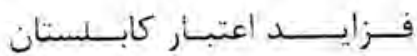

(1499 حوت (r.) 


\section{تاجيكستان}

تسرحبام فرخنده خاك، اي كل زمبن ثاجيكستان

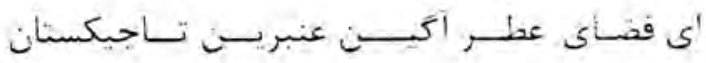

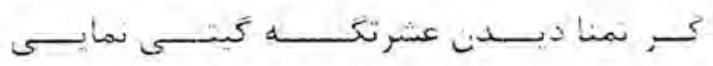

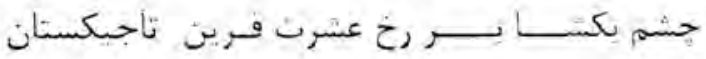

$$
\text { حسل و دل راباغ و بستانش دهد بك فيخل ديسكر }
$$

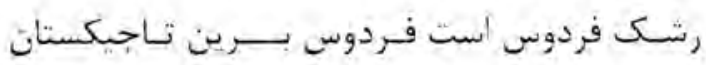

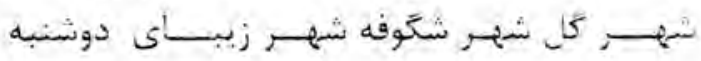

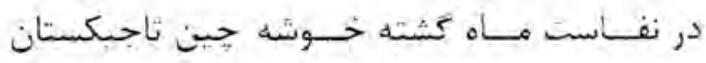

$$
\text { صلح خو'مى مير و رزى هست حون دربأي حوشان }
$$

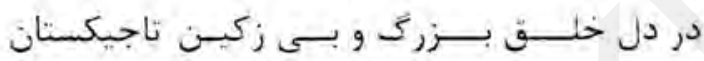

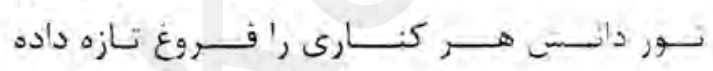

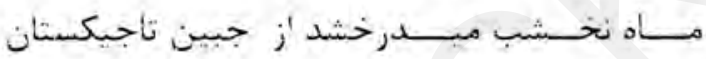

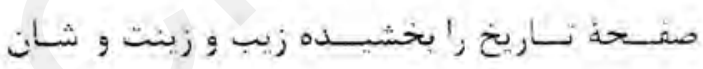

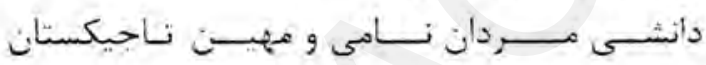

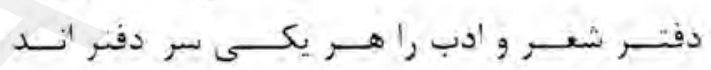

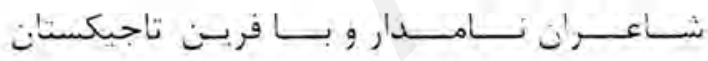

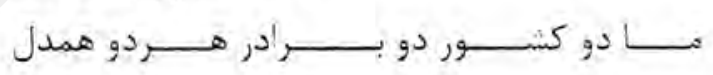

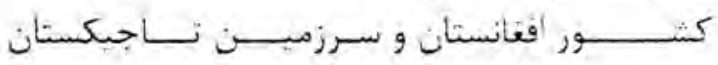

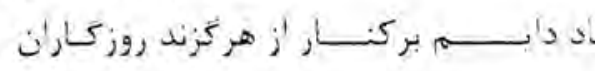

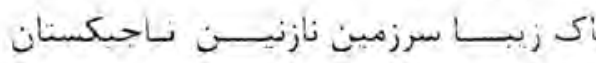

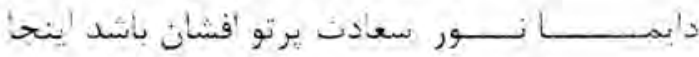

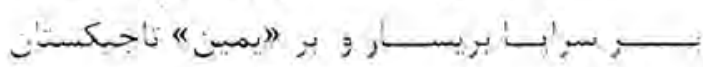

(9) 


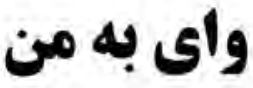

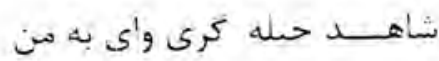

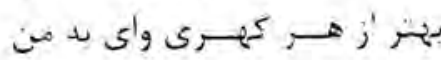

تو حو جان دكسرى والى بله من

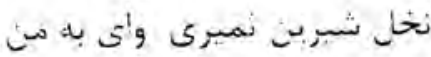

دلكشهمجيون قمرى و'ى بلدي

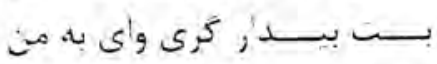

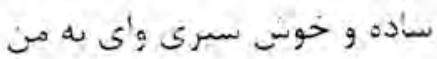

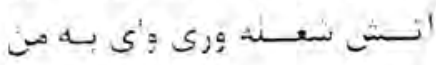

صنسـم حل هجـرى و'ى به من

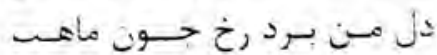

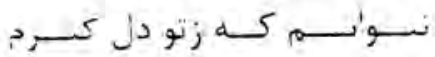

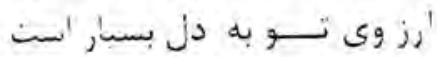

مبسروبد مل زنمسانسائى زخت

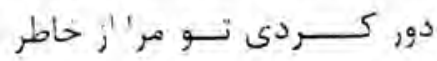

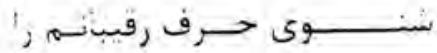

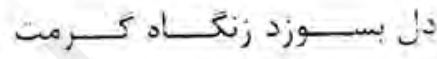

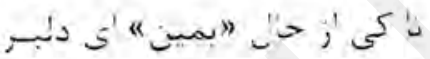

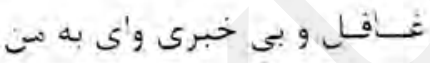

\section{سربازم و نواى ״به ييش!) است برلبم}

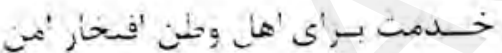

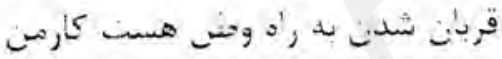

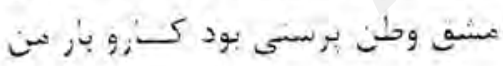

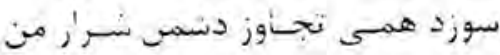

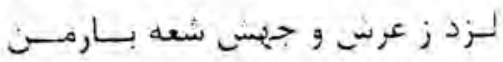

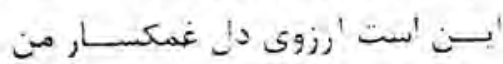

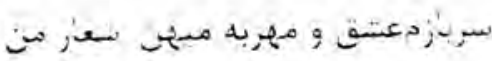

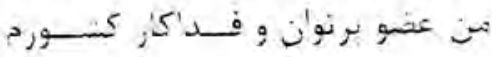

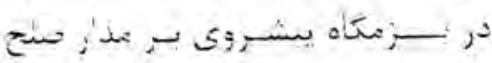

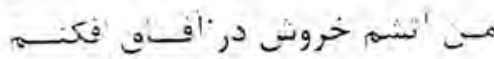

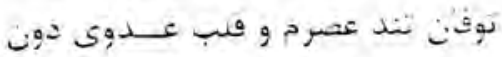

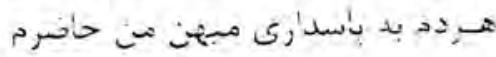

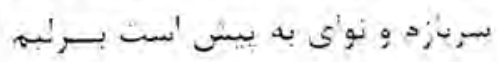

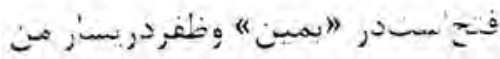




\section{هر دو}

به حان محسرك صد انفلاب شد هردو

دوتركست كمزمى نيمه خواب شيد هردو بـا نار مجمر عشقت كبـاب شد هردو به بك نظـر دل خونيئ و سينئ زلرم برأى كشتن من در شتــاب شد هردو

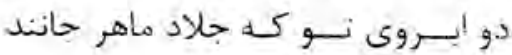
بناى عقل و حـواسمه خراب شُد هر دو به ملك دل سبب اضطراب شد هر دو زهجرت اي بت من غرق آب شُد هردو

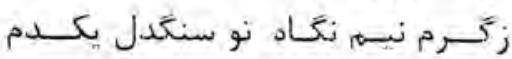
دورلف مشكى برث جوبن بةكَد رو افتاد

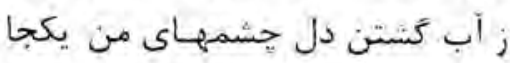
"يمين " اميـد وصـال و وفاى تو بكند

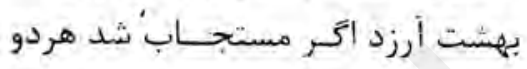

\section{هر دو}

سحر كنيمشب شخود به يَج و تابهردو همى به آثش حب الوطن كباب هردو بهراه عشق وطنسخت بهدر شتاب هردو تهى ميانه نباشيم حون حبـاب هردو كنيهماز بن و از ريشه اش خراب هردو

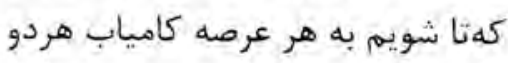

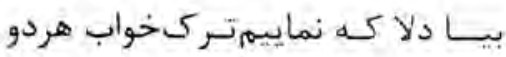

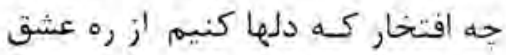
بيا كه تسبلى ها را كنيهم ترك و شَّويم

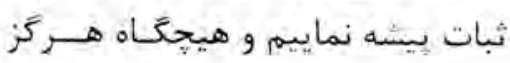
با كه دست به هم داده عمر خاين راتئن بيا كه عزت خورد و بزرى خود بكنيمه

$$
\begin{aligned}
& \text { زصدق همجو "يمين "هر كجابههر نفسى }
\end{aligned}
$$

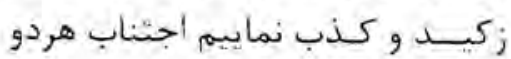




\section{بس از شب روز رخشان است يانه!}

به درد جنـع درمتان است ياته

بس أزشب روز رخشان استيانه

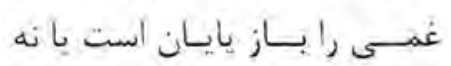

دجــار مـــوج ثنوفان است يانه

ينيمانسـى بــه ميـدان است يانه

خـلاف حكم قرآن است يـانـه

زكـارت عقـل حيران است يانه

به حسر و ششر ايمسان است ياند

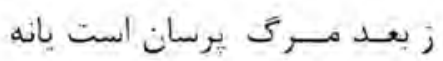

و اين خــواب بريشان است يانه

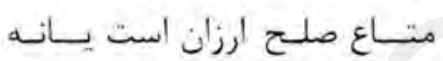

وولـن از جنـ ويران است يانه

همسه جـاشب بشد از نود باروت

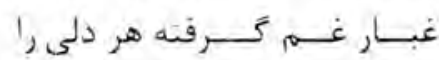

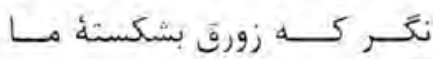

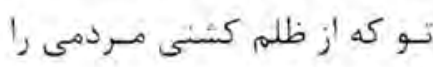

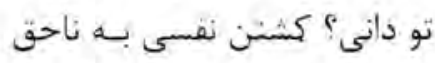

به دست خود وطن وير انه كردى

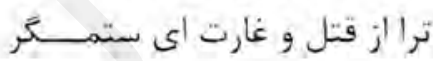

تــو كـهـ أمروز بيب المال دزدى في

تنبى من صلح رادر حواب ديدم

به دست از عقــل نقد صلح افتد

يمين ازدل همى خواهان صلحست فتست

$$
\text { دل تسو نيتز خواهـان است بـانه }
$$

(ITVT) 


\section{درد از دوا كذشته}

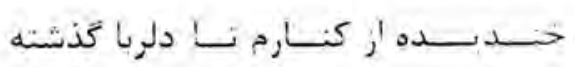

فــريــأد و شيــون من أز نه سما كذشته

$$
\text { س2 }
$$

نعجيـلـ كن كه وقت جون و جر' كذشته

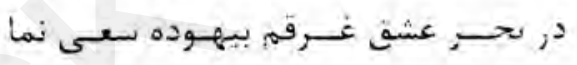

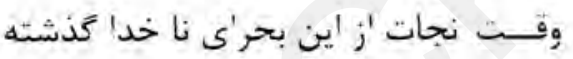

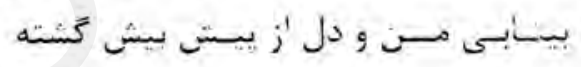

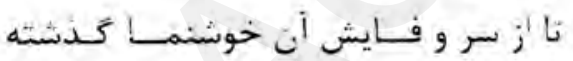

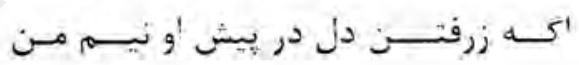

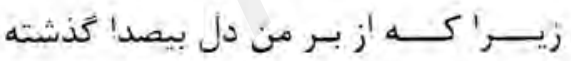

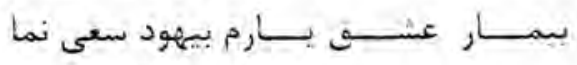

خيز 'ز طبيسب غافــل حرد إز دو' كذشيه

$$
\text { 'ى دوستـان نويسـيد بر لوح تربــ مسـن }
$$

هست 'ين نثهيد حانان درد آشينا كذشته

$$
\text { خـونين دل "نمنين " إست إز ديسرياز زير' }
$$

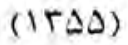




\section{فكاهى هنفوم:}

\section{تصوبـه}

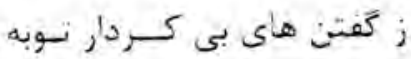

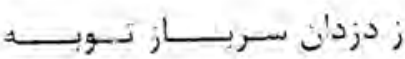

از ايسن حمع خيانت كار توبه

ازين خرجنت كج رفتر, توبه

هزار وسه صد و بسى بـار توبه

;كاكه شمسئم جون نار توبــة

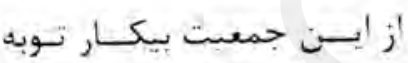

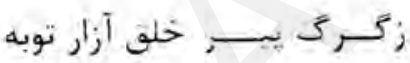

از إين روبه گ

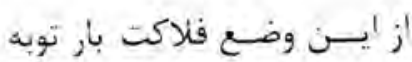

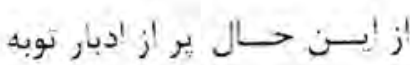

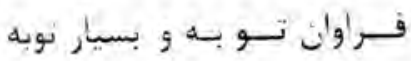

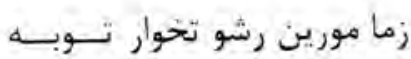

خورند هر ساعتى خون غريبان

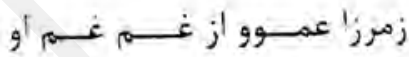

ز خنـاط و ز ســود نـاروايثـ

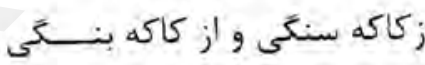

'زاينمفلث تكبر هاى حوديبن

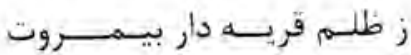

'ز 'ين قاحاق جى دشمن خلق

'إ'بن احوال و زين بسمانى ها

'ز 'إسن روز سرايـا ذلت انغيز

يمبن 'ز إينهمافر أط و تفربط

دواز 


\section{فكاهم هنظوم:}

\section{كاكـه}

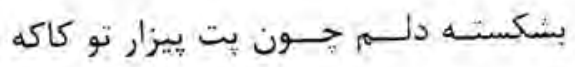

افسرده تنم حون خـــم دستــار تو كاكه

$$
\text { كر كشته دو گوش من بيجاره در اين شُهر }
$$

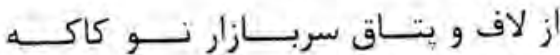

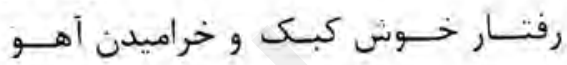

هركز نرسد هيج به رفتــار تـــو كـاكــه

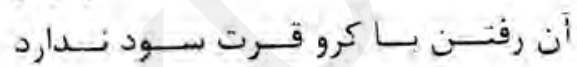

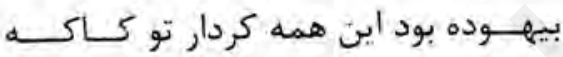

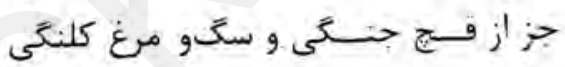

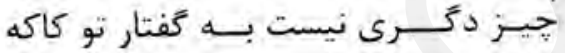

$$
\text { در نيفــه ات افيون قزون است ز يكسبـر }
$$

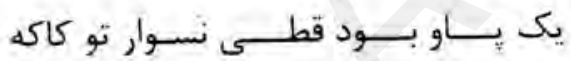

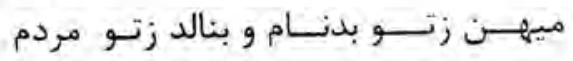

تـا جـــرس و جلم كشت كرفتار تو كاكه

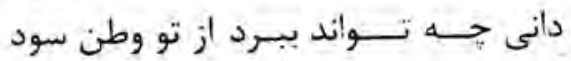

زيسـن وضسع و از ايـن شيوه ناكار تو كاكه

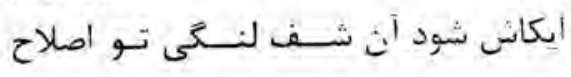

هم كرده و هم خصلت و يندار تو كـاكه

$$
\begin{aligned}
& \text { گويد به تو اين نكته "يمين" ار تو نرنجى }
\end{aligned}
$$

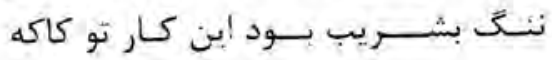




\section{بت بيداد كر}

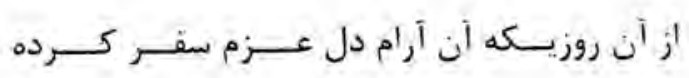

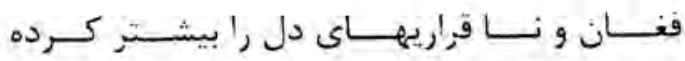

بسه كار دلبرى آن ماه حابك دست و خالاك است

بــه عين ساده رويسى اش ز خوبسان د كـر كرده

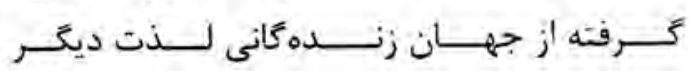

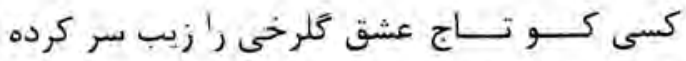

$$
\text { نما بــد خــــوار در جشمش متـاع اين جهان آرى }
$$

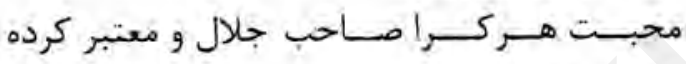

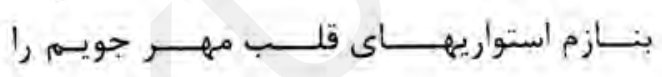

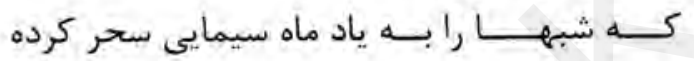

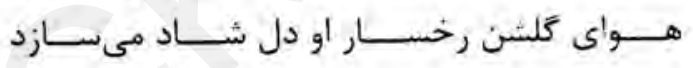

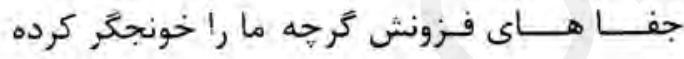

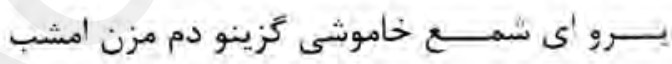

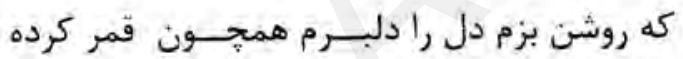

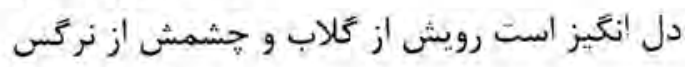

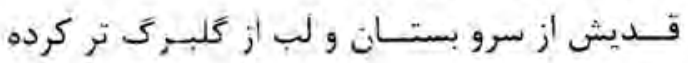

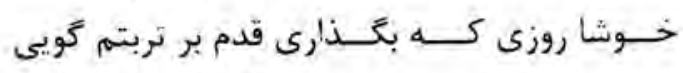

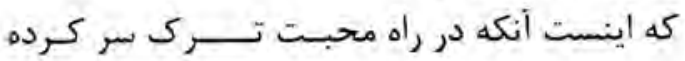

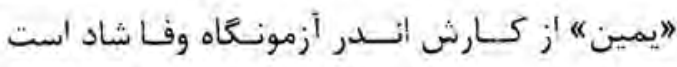

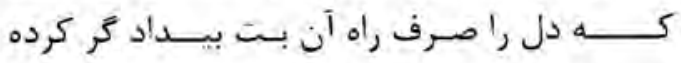

(1T2.) 


\section{رفتى}

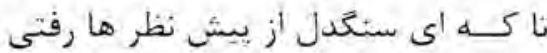

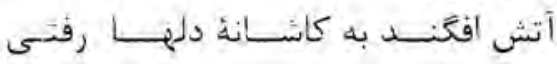

قلب خون كَشته و حونبار شده ديده زغم أني

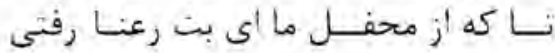

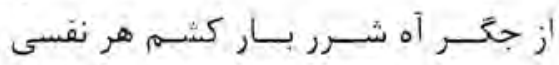

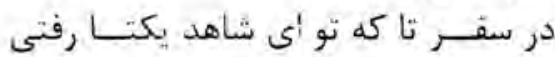

ناله ها بر فلـى از هجر تو بالا شده است از همان دم كد نو إى شوخ از اينجا رفتى

$$
\text { خـــود بـرفتى و نهادى به غم و رنج مرا }
$$

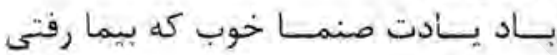

$$
\text { رفتسى و هجسر تو آتش به جكر زد ما را بـان }
$$

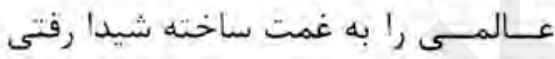

$$
\begin{aligned}
& \text { تــو برفتى و دل زار "يمين" رأ بــا خود }
\end{aligned}
$$

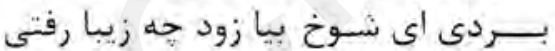

(ITF.)

\section{بيعانه تابكى ز مسايل نشستهاى}

دشمندسيسهساز و تو غافل نشستهاى

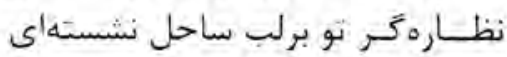

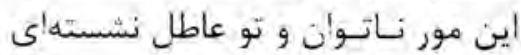

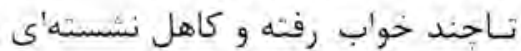

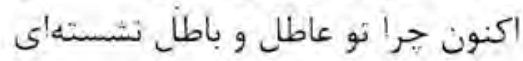

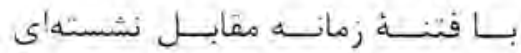

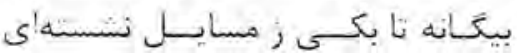

تاكى تو هموطن دل و نادل نشستهاى

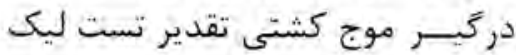
شد قـرنها كه ميخوردت مغز أستخوان خصم تو سرنوشت تو تاكى كند تعيين تو سرنوشت سلر وطن بوده الى همبش نونس هشدا, هموطن كه در اوضاع و حادثات فكسرى به حال كنّورو مستقبلت بكيل

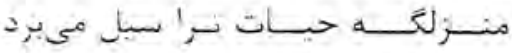

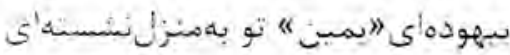




\section{غزال آرزو}

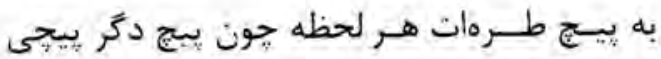

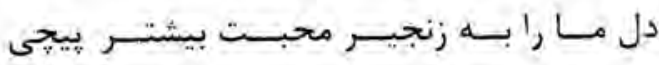

كجـا كَنجــد بــه و هـم خلق أن موى ميان او

دلا تساكسى به كرد هيج هر شام و سحر بيجيى

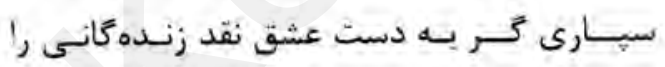

تــو طور مـار حيـات از كوهكـن شير بنتر بيجى رلى

$$
\text { جسر' 'جون خس زهر مادى بر يشان ميروى آز جا }
$$

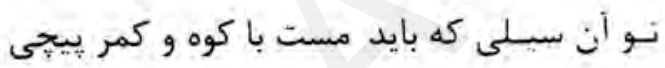

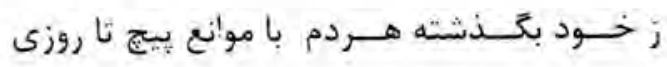

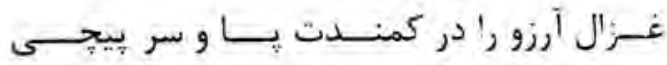

$$
\text { من أن موجم كه إز من اي فلك دلشاد كى كردى }
$$

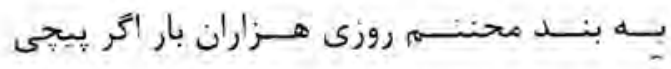

$$
\begin{aligned}
& \text { "يمين " أشحا معماى حبات 'فتّاده بسيل مشكل }
\end{aligned}
$$

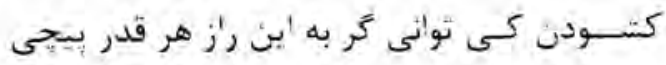

(ITFQ) 


\section{ترا دامان كوتاه و مرا دست}

بيــا 'ي نـو بهــار جــاودانسى

بياكافسرد قلبمن تو جــانى

بيـا عشقمر كـهـ بتو تاب و توانى

لبــان بــوسه خيـزت أرغوانى

بــــين تمكين سرايا كلمستانى

بـود دستم به دامانت رسانى؟

مر ! با خود به هر سو ميكشانى

كـــه دلهـا با نغاهى ميستانى

به قلبمه داغٔ هجـــرانت نشـانى

تو سرتا يـاى نـازى آسمانى

ولى رستهم وفــــا دارى نـدنتي
بيــا إى آفتـــاب زنـــدمانـى

بيــا بــاغ اميــــدم رأبيـاراى

تماتــده در تنــــم تاب و توانى

دوجشمبدلشكارتشاهبازى شت

قدتسروورخت

ترا دامسـان كوتاه و مرأ دست "تو خورشيدى وِ منسيارمثو" تويسـى آن غنجهــــ باغٔ لطافت منـــم آن لالـه صحرا كم باشند ســرائـا من نياز استمر زمينمى بسه كـار دلربايى حبره دستى

$$
\begin{aligned}
& \text { بيـا روزى نغـارا شاد كرد' }
\end{aligned}
$$

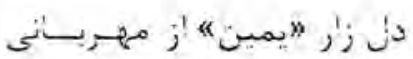




\section{بهبار}

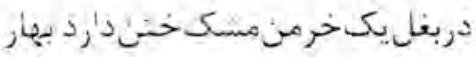

حون برند نيكونى بير اهن دارد بيهار

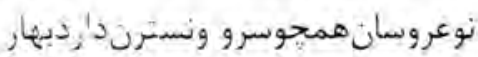

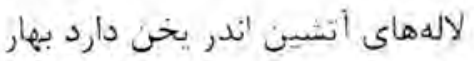

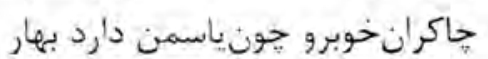

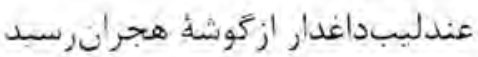

رفتسرماوبه صحر' لالئخندانرسيد

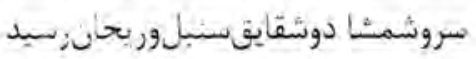

قمرىويروانهوهمبلبل خوشخوانرسيد

فرشزيخارىز سبر هدر جمن داردبهار

لالهمبروبذبه كومودشَ دندرهر بوم و ير

ميخر امدتيسر إيدكبكنر كوه و كمر

ميـوزدهردمثسيمصبح جون مشكتتر

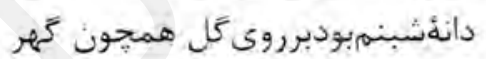

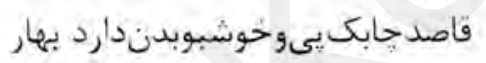

نالهماي جانكداز ازسينه بلبلميكشد

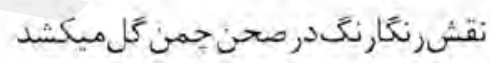

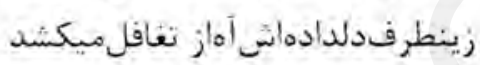

زان طرفبر طرئخودنشانه سنبل ميكيند

عانقومعشوق هميوجانوتين داردبهار

شوروافغانو نفير از اهليانوهمروموش

هأيوهوى غندليبان مير سدهر دمبن كون

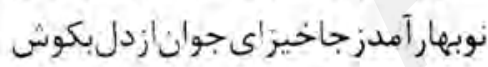

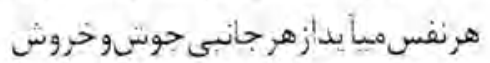
أز براىسعى براز

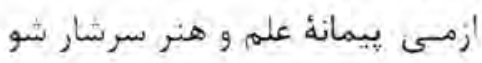

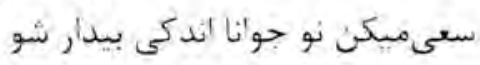

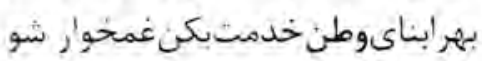
جدوجهدى اينصيحتر ابههر فردوطن دارد بهار

بادل خوش جائب كلز ار ميكر دد روان

شادوخرممينما يدروحدهمان'ينزمان

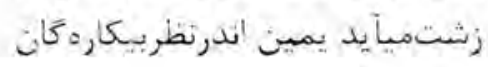

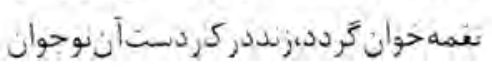

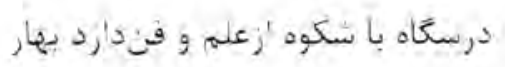




\section{- \\ ضرور است}

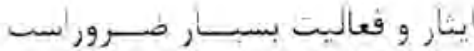

درمجدتوبسيار كنون كار ضروراسب

$$
\text { بير تو جوانسان فـدا كار ضرور أست }
$$

صاحبشدى گر جه توفابر يكه بسوزن

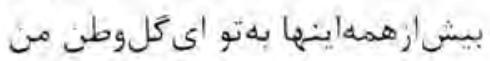

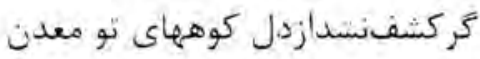

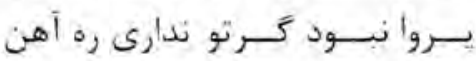
مردانصفاطينت و بركار ضرور است

تـانسور ترقى كند اين خاك سنور تـا جـامعه مــا نتـود آباد سرانسر

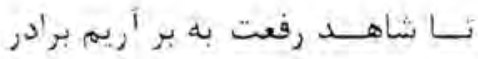
مــا را بثنسود نـا كل مقصود ميسر بأكدى أزدل شدن همكار ضرور است

نبكـونست كه برنفع هم إيشار نمانيه

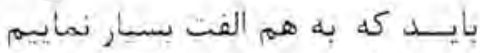
بابد كه محبت به هم اظهار نمانبم

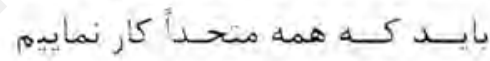

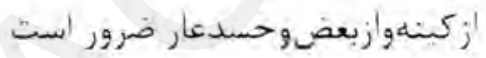

تادرتن أبن خاك شود روح نو ايجاد

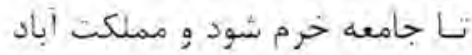

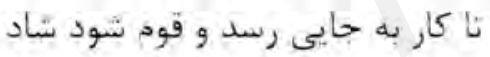
تا دل زتسـرقى شـود إز ســدغم آزاد

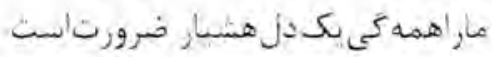

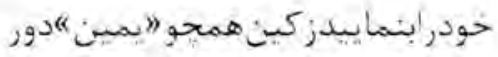

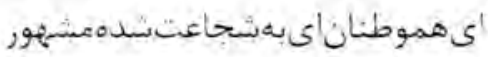
>و'هبد أتر مملكت خود همه معمور بائشيد به هم متحد و خرم و مسترور بهم نسدن همكار وفادر ضرور إست 


\section{مخمس بر عزل حافظ}

دل را رها زانده و ر ربستج و عداب كن

دور اُخ رخح ابسى نكار خدا رانقاب كي

صبحاستساقيا قدحى بر شراب كن وني

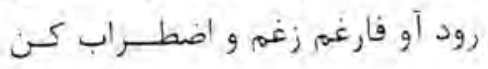

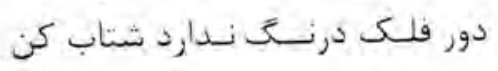

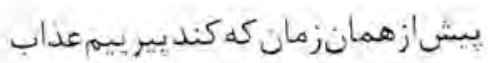

زان يبشتر كه عالم فانى شود حزاب

بشاز دمى كه در كذرد دورة تَباب

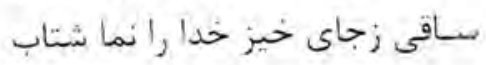

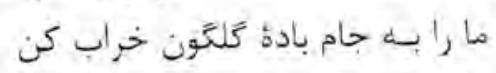

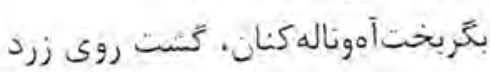

ز ريابشد رقيسب حهـو در عبرضهة نبرد

خرشيد مى زمشرق ساغر طلوع كرد

مطربواخت نسازو ز دلهيا فشائد كرد

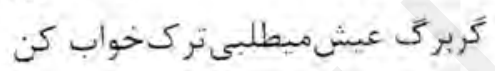

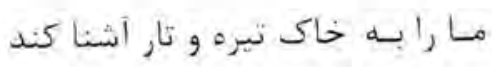

جون مرك روح ما زتن مـاجدا كند

روزى كثد جرخ از مل ما كوزه ها كند

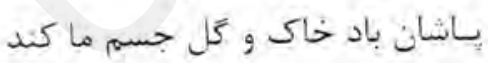

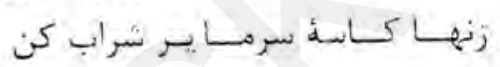

مابستهاي "يمبن "بهمباهات نسيتيمه

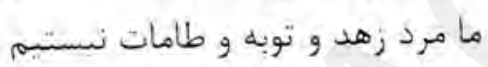

ماغسرق در ريسا و خر افات نيستيمه درحرت فو فكر جاه و مقامات نيستيمه

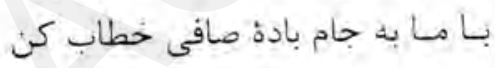

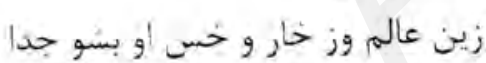

تا إز حيات خويش شوى بيره ور بيا

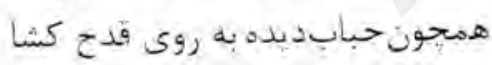
از خلق شو كنسار و به ميخانه رونما

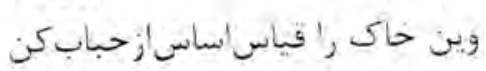

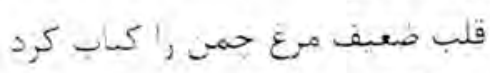

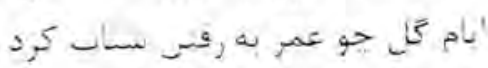

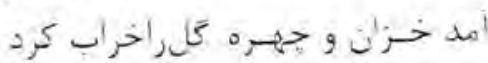
حافظز جاى حست وبهسفي خطان كز

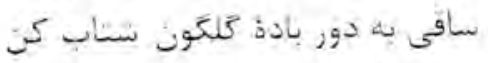

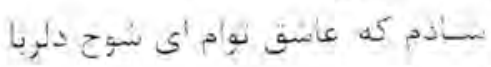
هر حتد همبت كار تو حهور و حفا بلا

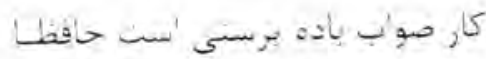

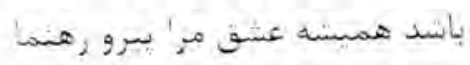

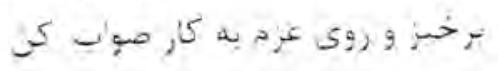




\section{مخهمس بر عزل حافظ}

عاشَقى خواستهِيرو جوان خواهد بودن

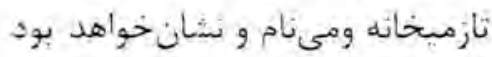

تاكهازيشق همى سر حوبيان خونهدبود هركحا قصأ عتاق جهان خواهد بود سرما خاك در بير مغان خواهد بود

تامى اندر خمهر مبكدهيى برد حوس است

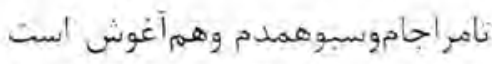
حلقة بِير معان أز أزلهم در كوش است خمميخانهميى نا ببدم بردوش است برهمانيم كدبوديمو همان حواهد بود برد

ياس در كاه محبت نوهمى دار نعاه

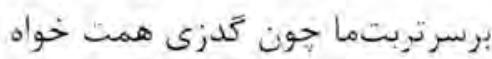
قدمى كر نهي اينجا نكرى عزت و جاه

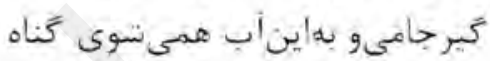
كه زيارتخه رنسدان جهان خواهد بود

قدح از يبرمعان خوأه و همى عزت جود

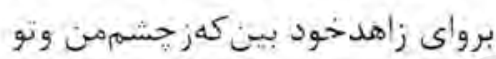
كر بهميخانهرويىجامبة كف كيرو سبو

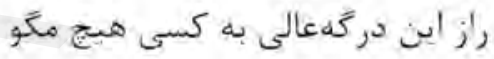

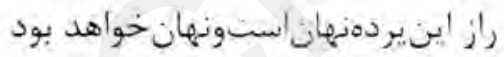

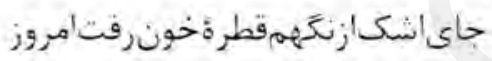
يار'ز'ينمحفل بر طنطنه جون رفت أمروز

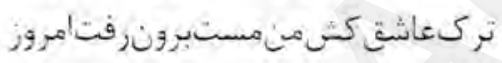

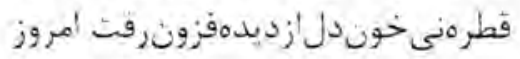
تادكر خون كهازيده برون خواهد بود

سخنت جوهر احساس بـه دلها بتزيد لب تو كار مسيحا كندي و جان بدهد

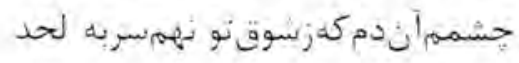
ياد نو تا كله جهان است ز فلبهر نرود

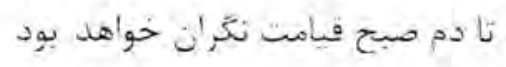

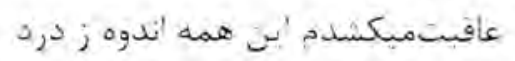

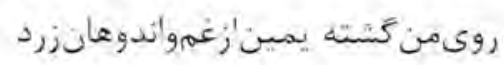

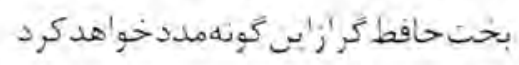

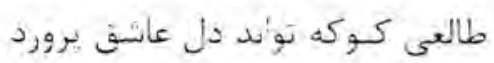

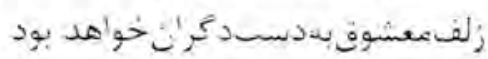

(ITAT) 


\section{مخمس بر عزل شهريار}

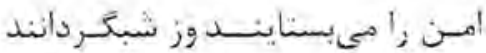

ائبسا بى هز أنخويسَ هنر وز خوائند

روشناييى كم به تاريكى شب كرداثند

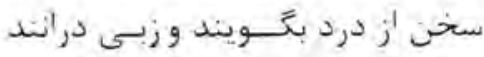

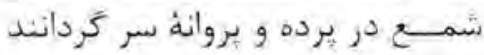

هر كه أزجان كَّردميشود انسانى فرد مردشو مردكة درعرصه وميدان نبرد خودبده درسمحبت كه اديبان خرد هوشكنتا نشود آثشاحساس توسرد عمد در مكتب تحقيق تو شاكردانيد

وتســـرين راه همه در طلب او يويند حستدانى كه ورا نامحفيقت كويند توبهد لهستىوابنقوم بدكلميحوبند ائ حقبقتهمه كان عطر خوشتميبويند

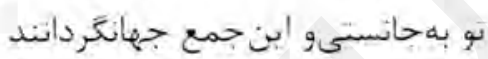

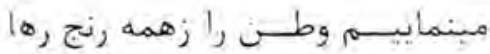

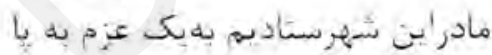

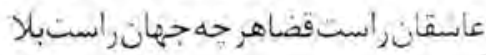
هستدر كارمحبان همد جاصدفو صفا نانزم آن قوم بلا كشى كه بلا كر دانتد

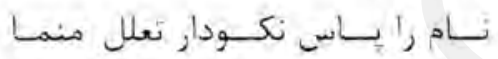

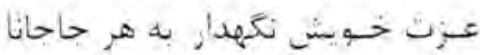

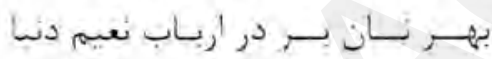
همحكَّه نأم تو مفروش به نأن أى دانا مرو أى مرد كم إين طانفـه نامردانيد

جأيخزينتو اندر صف وحميع عنوى تو بر افرور همى شعله و شمع علوى

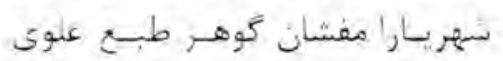

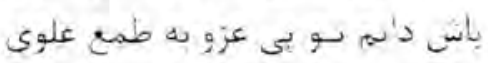

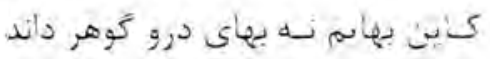

(IrAT) 


\section{مخمس بر عزل احمد يروانى}

سردم بسا افتخارى داشنم درم هنوز

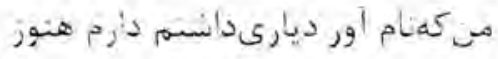
من كه اففانم وفارئدائمه دارم هنوز

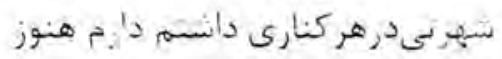

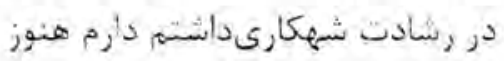

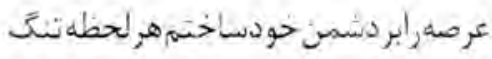

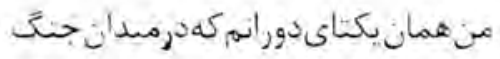
همر هانهم بر حهو شمشبر يارمن تفنى

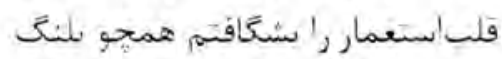
از دمخنجر شرأرى داشتم دارم هنور

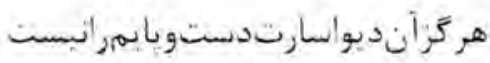
هبحكاهم خصم:نتوانستونتواندشكست

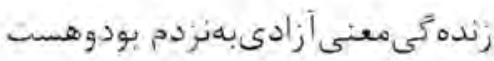

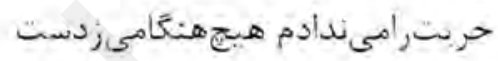

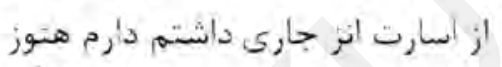

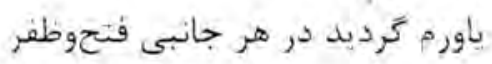
شدعدودر هر كجاز نستمن كوبيدهنسر درشخاعت نمرأصدفيصدمميداد نهر سهرت جانبازيام شدفاشدرهربومو بر روحاستغنا شعارى داشتم دارم هنوز

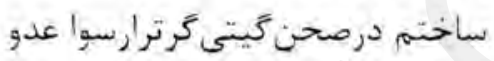

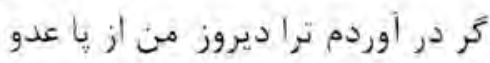

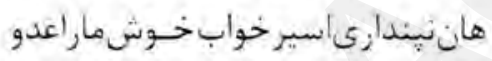 باخبر باشى كهمست آن غير تمبر جاعدو بـرق تئنِ آبدأرى داشتمم دارم هنوز

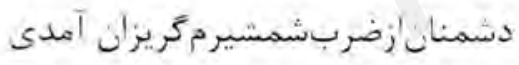
بحرقهر مي "يمين "هر كهبةتوفان آملى بـ

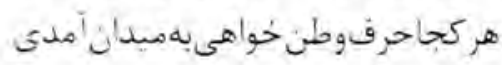

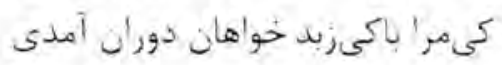

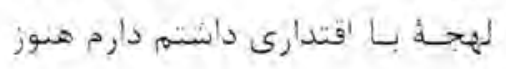

(1) 109 ) 


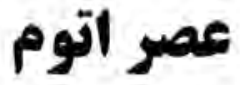

فلنك مـزور و"عدار سخت عيار است

فنكستمكرو غم كستروجفا كار است

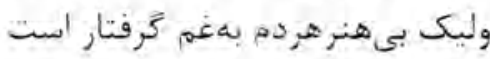
هنرور أز ستمش دابما سبكبار است كتر است

زمانة اتم و عصر عصـر ماشين است

هنرگز بن هنر عزو جاه و تمكين أست

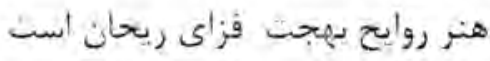

هنر نسبهم عطر ببز هر كلستان است هنت

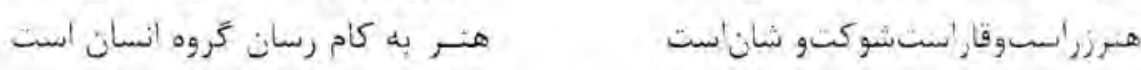

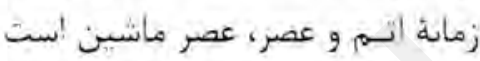

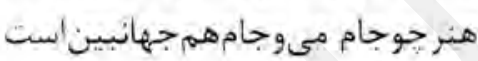

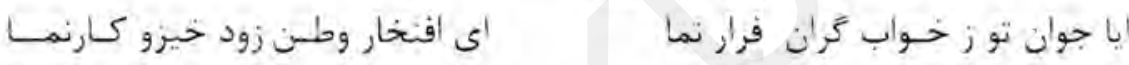

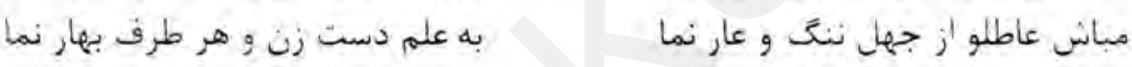

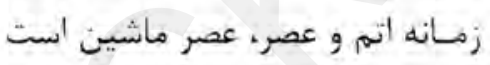

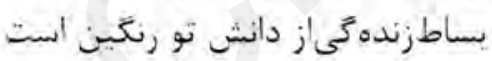

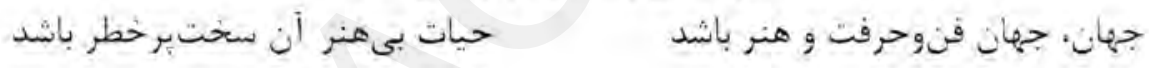

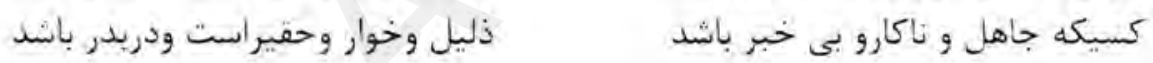

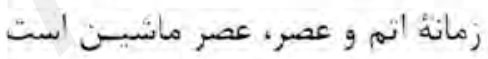

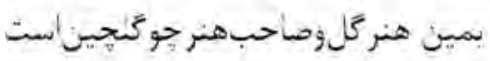




\section{هوش ميكن لاف بيموقع مزن}

بابسه يبيش عـارف صاحب سخن جـون نشيسى روزكى در انجمن

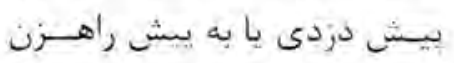

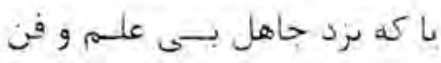

باشى هر حابى كـه نـو ائ لافزن

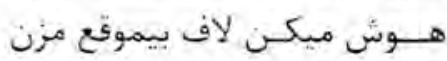

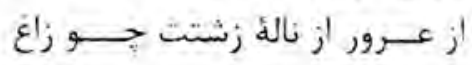

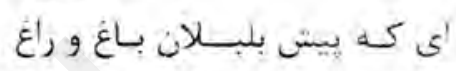

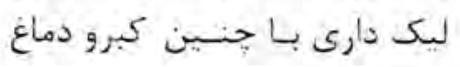

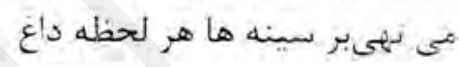

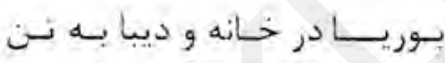

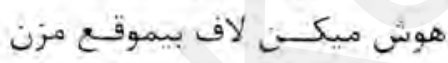

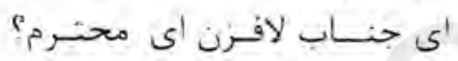
كر حه دانمه اين معمى يك قلّم:

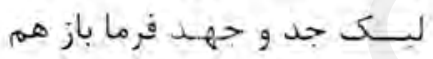

مى كتى وقت سخن از صدف رم

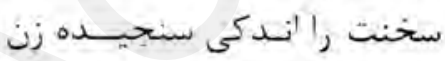

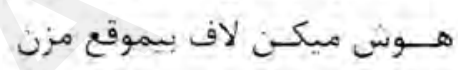

نا شوى از راستى ات رنسته كَار 'ي برأدر زاستسى را! دوست دار لاف بيجـايت نمى آيســد بنه كار

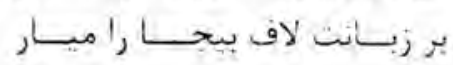

هور كن اين لـكة را دور أز بدن

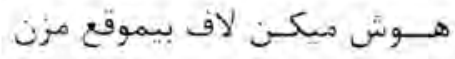

كأ كه بـاشتى با سعادت ها قرين

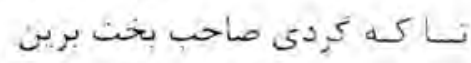

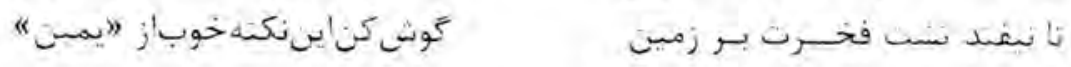

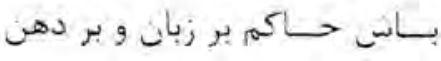

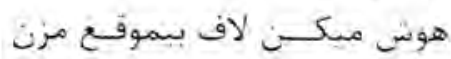




\section{مeم}

اي زئسو سر سبز بستسان وطن

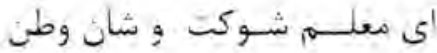

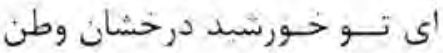

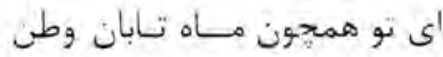

$$
\begin{aligned}
& \text { أي معلسه ائ جهبان رأرهنما }
\end{aligned}
$$

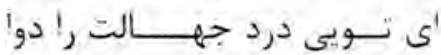

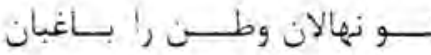

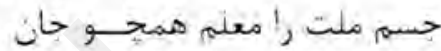

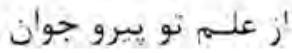

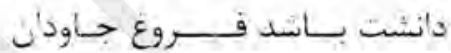

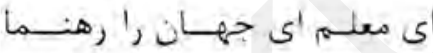

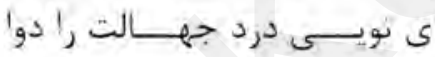

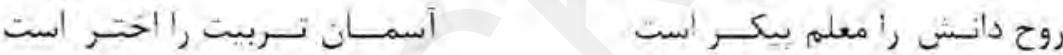

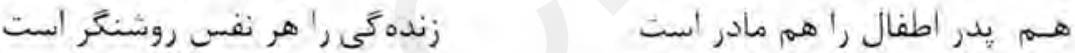

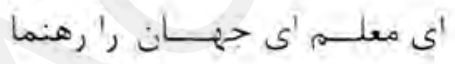

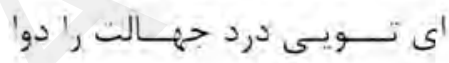

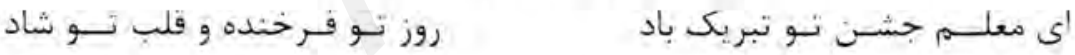

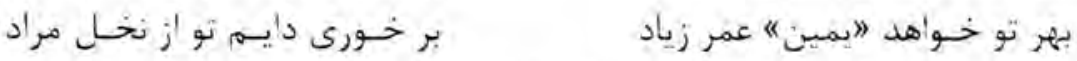

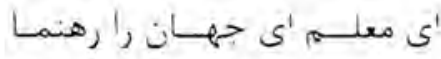

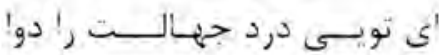




\section{آزادى}

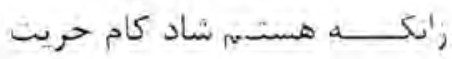

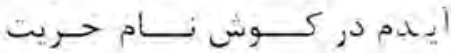

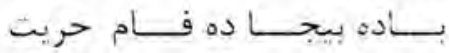

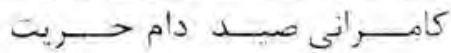

كـان بـود سر شـار جام حريت

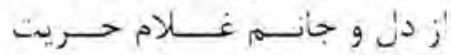

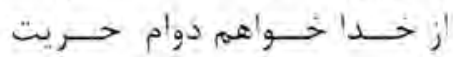

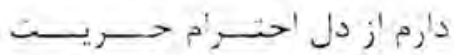

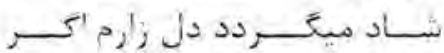

روح بخشى است و سبرور !فـر' بود

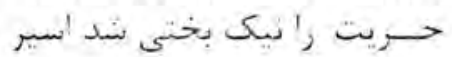

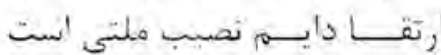

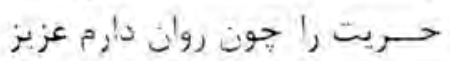

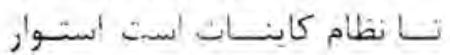

مملكت حسم الست وحريت روان

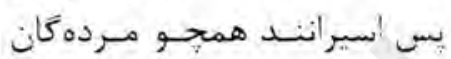

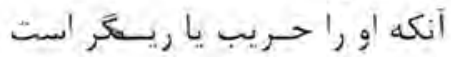

بـا سعادتيها قرين آن كسود است

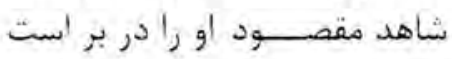

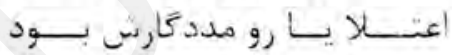

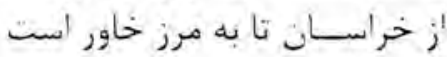

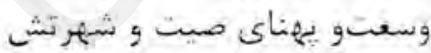

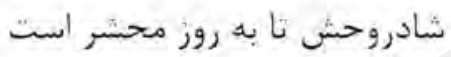

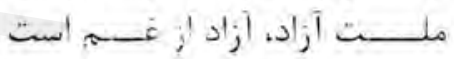

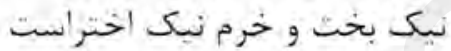

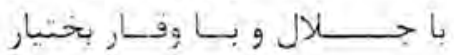

هم خدا هم بنده كانش ياور أست

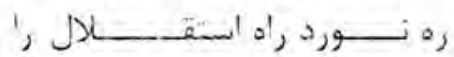

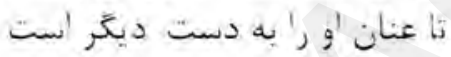

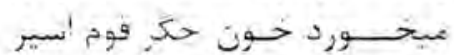

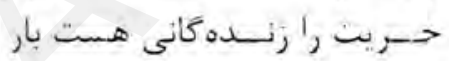

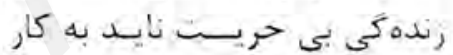

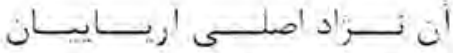

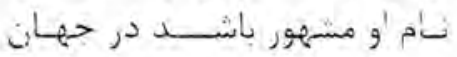

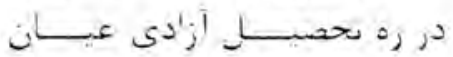

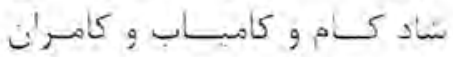

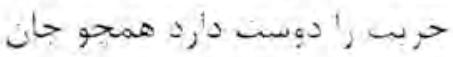

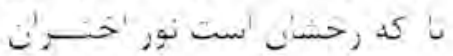

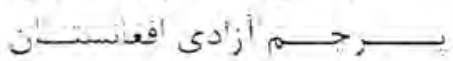

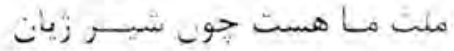

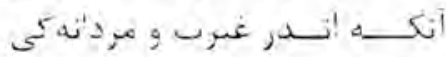

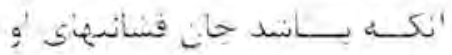
آنس

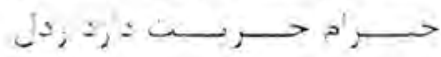

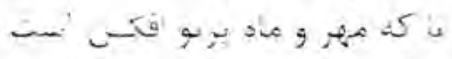
तs

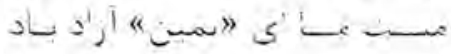

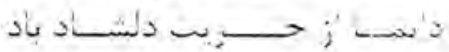




\section{در سوت ليلاى صراحت}

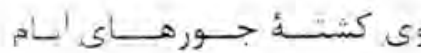

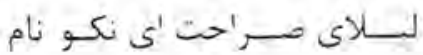

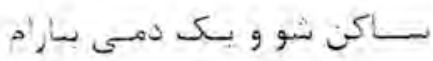

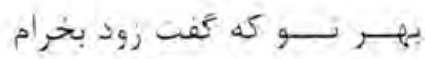

مشثداب، مرو كة راه دور است

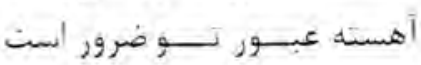

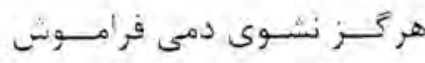

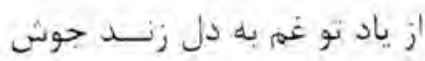

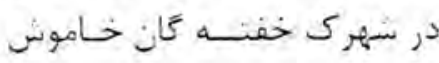

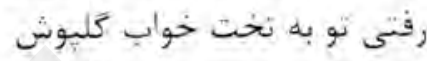

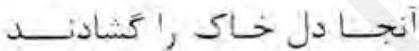

$$
\begin{aligned}
& \text { وز بهـــر تسو كوشكى نهـادنسـد }
\end{aligned}
$$

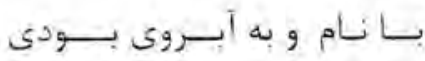
ليلـى تـو نيكوى حوى يوندى

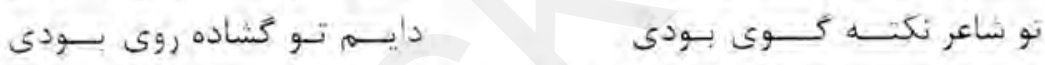

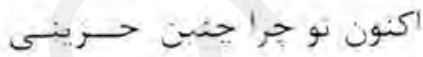

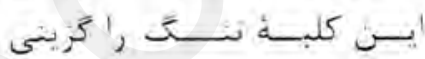

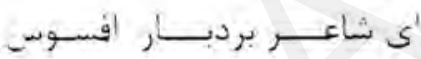

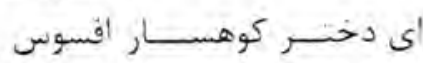

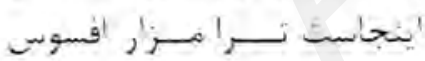

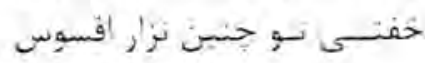

$$
\begin{aligned}
& \text { ' }
\end{aligned}
$$

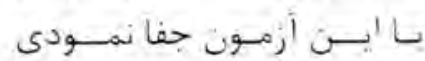

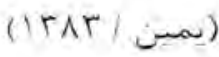




\section{جار ياره هاى همبسته}

\section{زندهى در آكهى است}

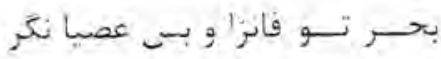

زئدمكى بحر استمسحونموج بمر

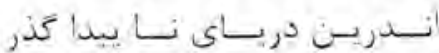

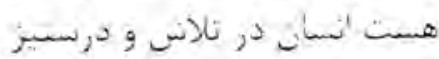

* * * *

هــم موافــق هـم مخالف بادها

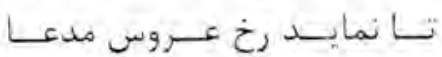

* * $*$ *

جاراهى نأكنه جندين راهى ابست

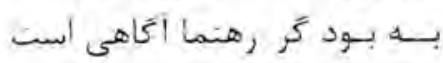

* * * *

بر همان , كو كو به معصودس برد

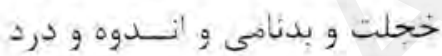

* * * *

مر نظر آيد به هر سويس سراب

هست أنجا هم يكى رخشندهآ لهن

* * * *

كو سعادت رابود سر جسمه يتى

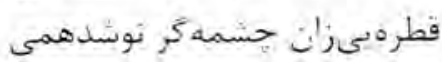

مبوز 20

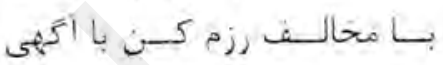

29 رأ

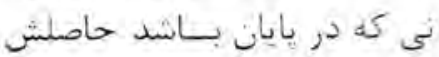

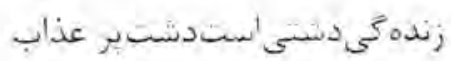

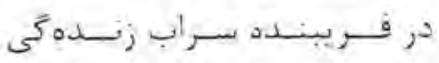

* 范 弥 
مادر

مادرم أي مادر بـــ اختـرم

از تسو روسّد أسمسلن كسنورم
مـادرم الى مسلحر جـن برورم

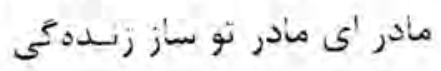

**** * *

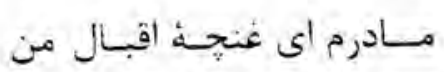

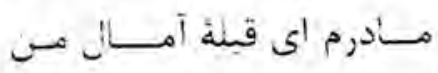

أى تو شمع حال الستقبال هن

مــادر اي مسادر زلى باع مراد

*

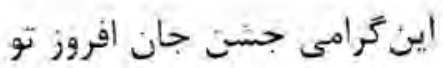

مسدرم تبريك حشن و روز تو

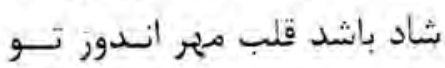

بـاد دايـسم نـام تو زيب كلام

* * * * *

هر كجا باشتهم تويى در خاطرم

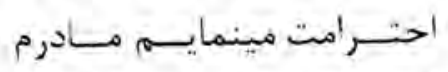

از تسو روشى ميهنم بوم و برم

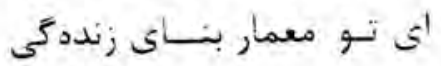

$* * * * *$

$\Delta 1$ 


\section{عصر نو}

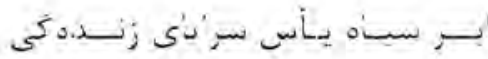

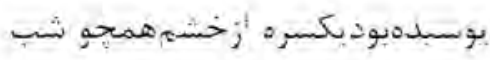

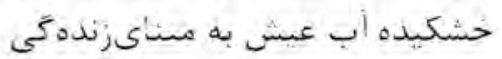

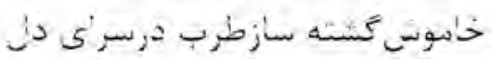

米米米

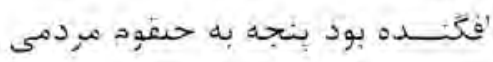

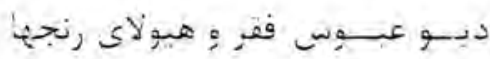

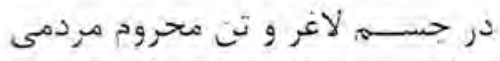

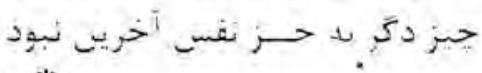

* $*$ * *

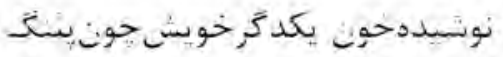

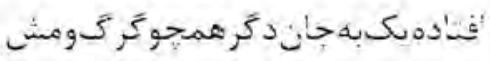

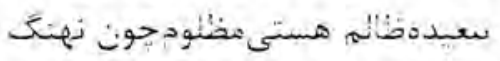

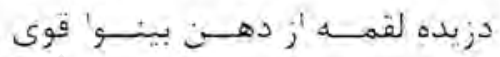
* * * *

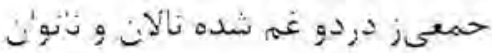

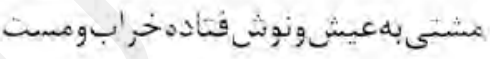

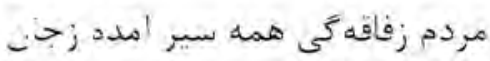

* * * * *

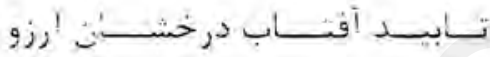

بنارى دميد بـرق زتوفــان مـردمش

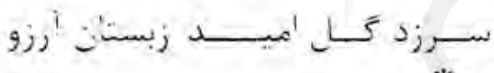

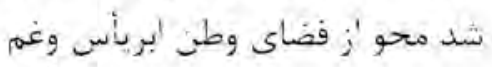
* * * * *

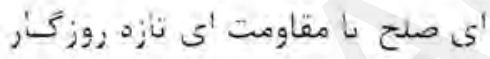

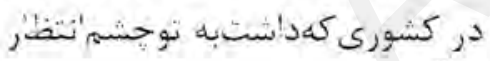

* * * * * *

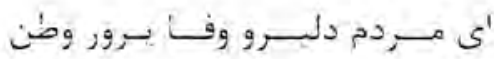

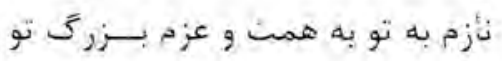

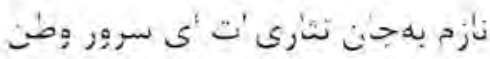

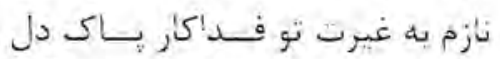
* * * *

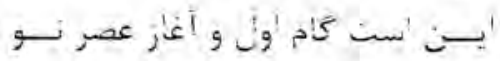

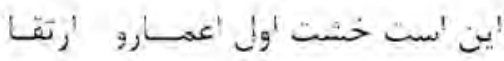

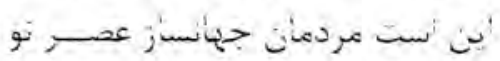

** * * *

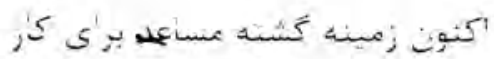

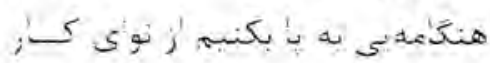

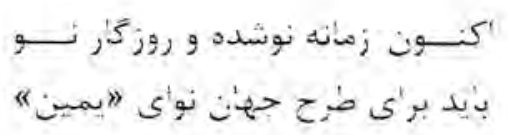




\section{مادر}

ايى روشأز تو منزلو ماواي رُندمثى

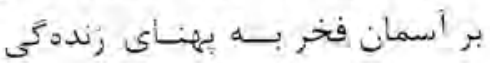

'ى مسادر أى تسو منبع آمال و أرزو

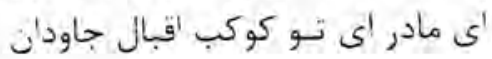

* $\%$ * * *

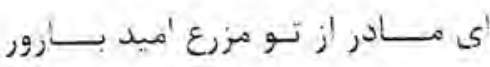

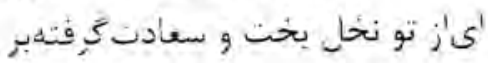

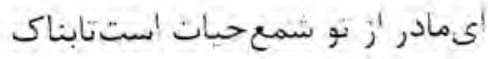

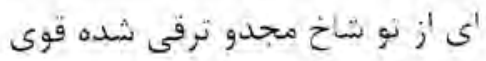

**** $*$

زانسـوى تو خجسته دبستان مـا بود

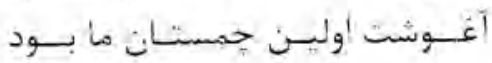

دست تسـو رهنماى سترك جهائيان.

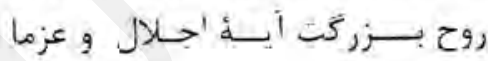

* * * * * * *

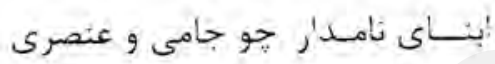

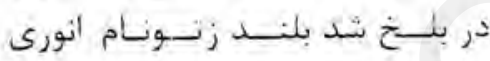

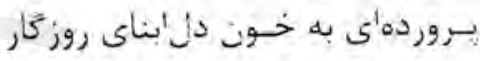

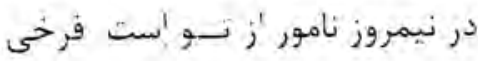

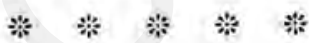

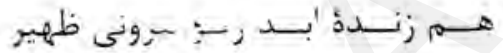

جون مولوى و ر'بعـهـ مُ ناصر ونصير
شد بوعلى بـ همت تو شهرة: جهبان

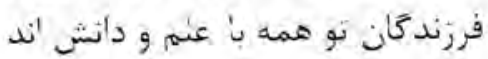

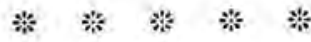

أن كسى كه 'و نهاد قدم ر' بهماهتاب

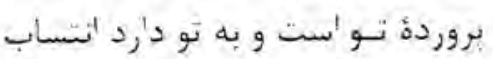

* * 施

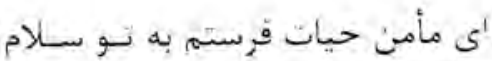

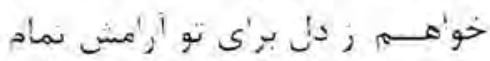

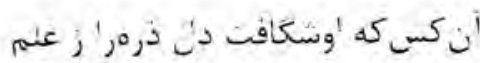

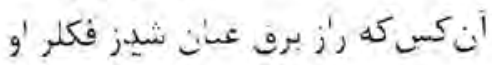

* * * * 


\section{قلب آسيا}

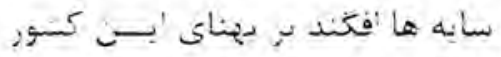

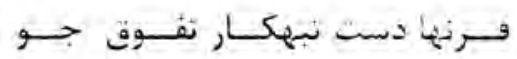

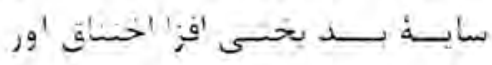

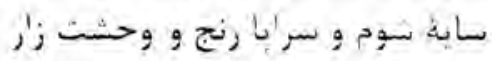
* * * *

كأل

ار

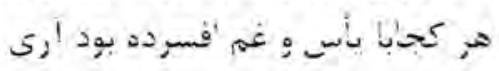

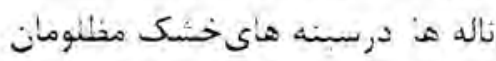

* * * *

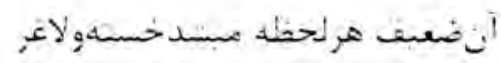

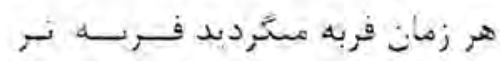

* * * * *

بود هر ح' در حدبر مستى مسردميل

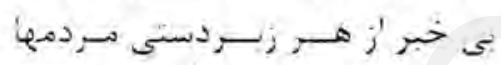

* $* * \%$

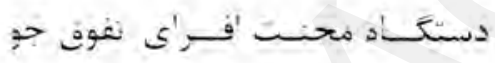

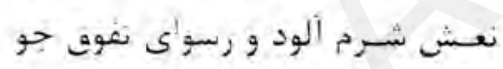

* * * *

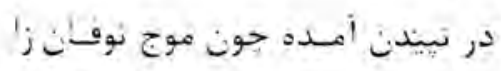

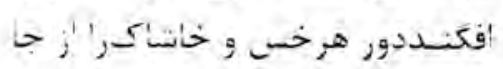

مي مكسدبـد خـون ملت أن تبهيكار'

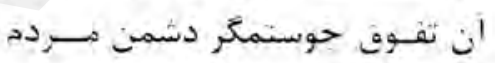

عاقبه درهمتشكستاينمردممخر:ن

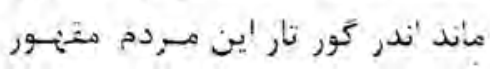

* * * $\%$

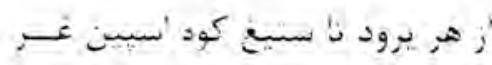

فㄹ,

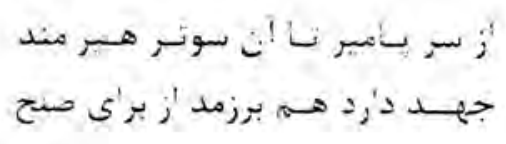

* $\%$ * * 


\section{لاجورد}

لاجسور دبـن اسمن مــردئ

نسبز كسب حـ * * * *

كs

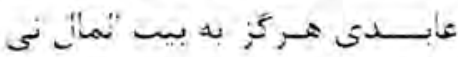

*

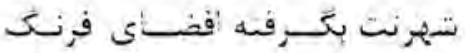

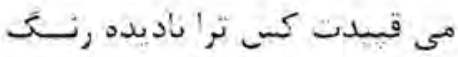
*

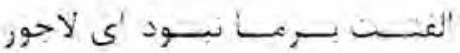

خ

*

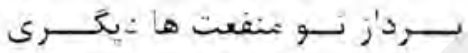

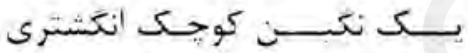

* * * * *

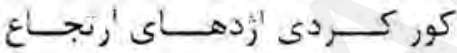

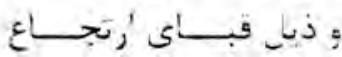

'2

*

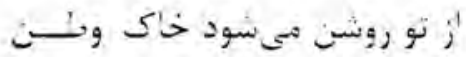

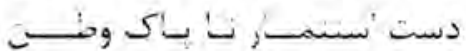

* $*$ * *

.

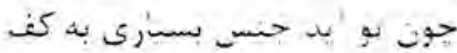
* $\%$ * * * *
إ

ك. بنسمباب ز سرق ميرفمى بــ عرب

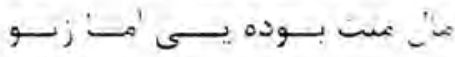

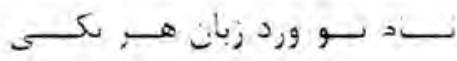

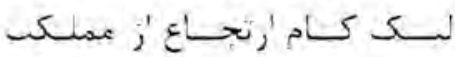

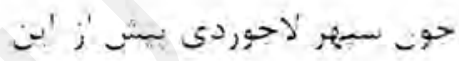
- - -

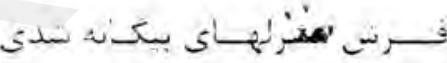

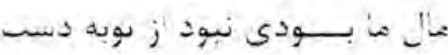

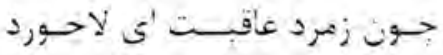

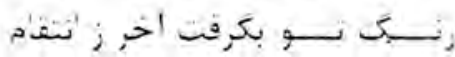

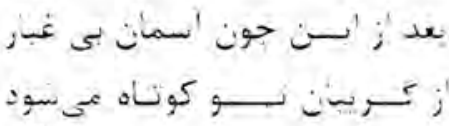

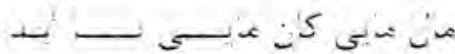

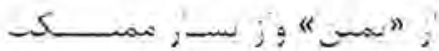

* $\%$ * 


\section{جار بِاره هاى آزاد}

$\longrightarrow$

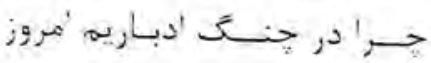

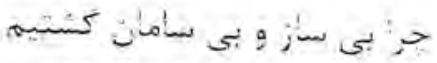

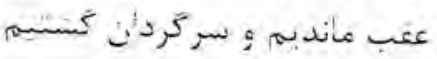

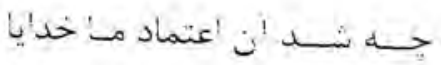

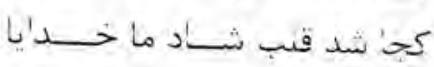

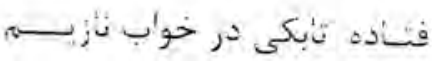

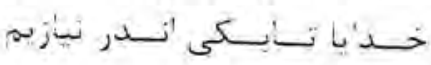

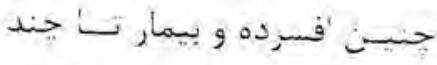

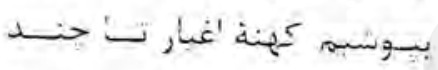

جر

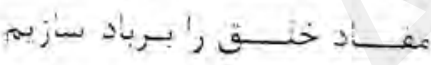

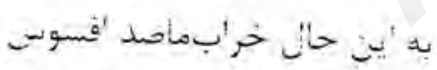

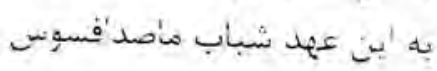

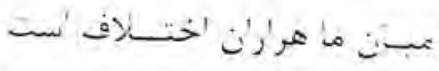

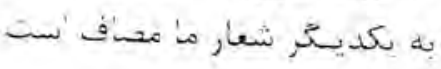

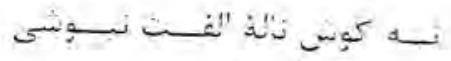

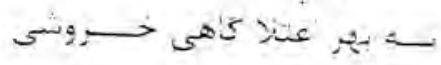

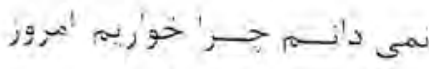

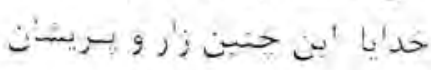

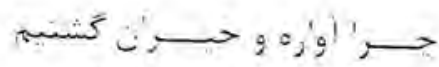

ح

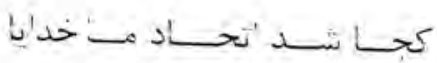

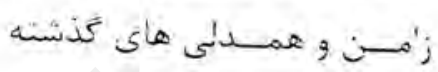

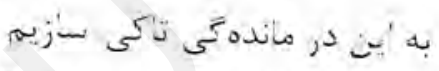

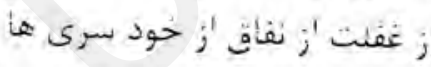

به 'ين حال خراب وز'ر بـ جند

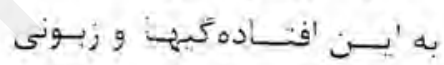

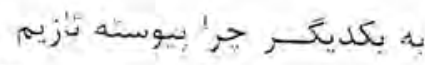
جر' بر نفع شخد خويشى مرجا

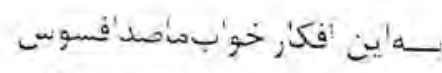

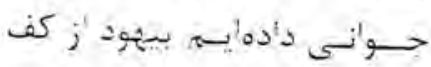

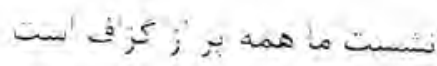

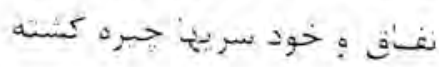

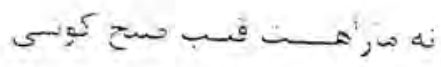

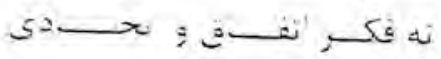




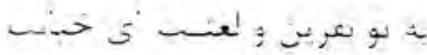
5 كو خصن

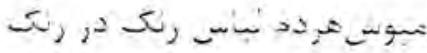

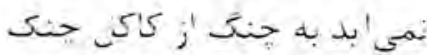

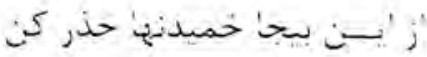
ز

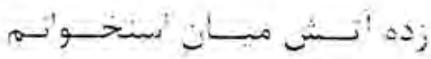

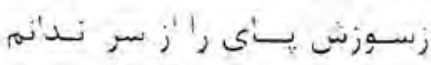

شر'ب امسن حر جنهـ نديدم 'مبد صبـع در شامس نـ نـدم

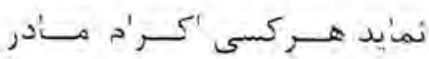

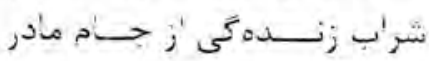

ن

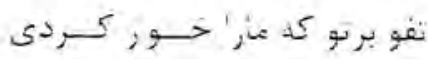

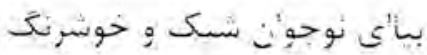

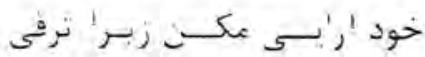

$-5 ;$ -

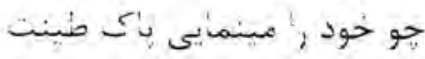

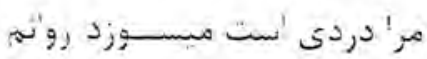

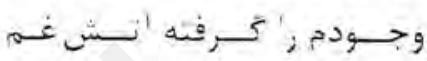

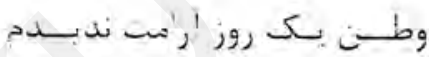

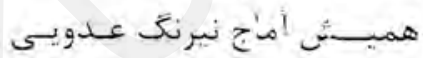

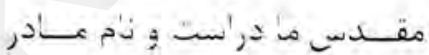

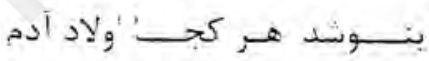




\section{بخش مثنوى:}

\section{زندهكانى را تحرك رونق است}

كشور أفعاندران يكر دل 'سب"

إسبا بك بكر أب و كلى 'ست

روبه هسنتى و حهنس بنهادهاست

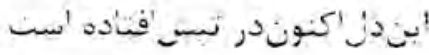

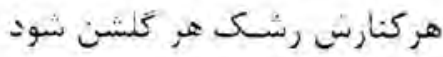

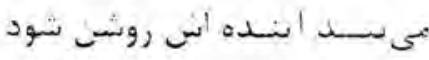

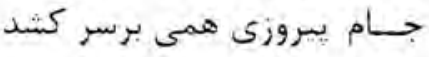

رب سب ساخ مسرادس بركند

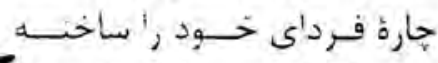

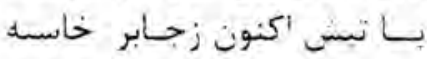

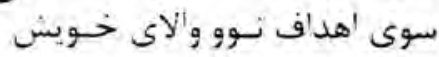

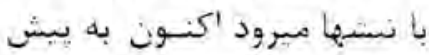

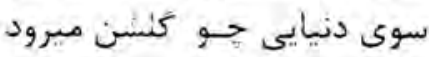

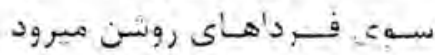

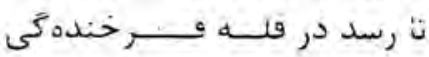

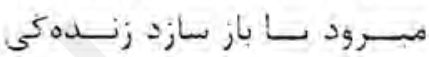
زندهكانى إز تحرك مئتى است

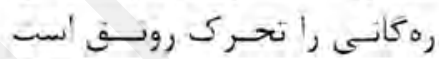

با تحرك سوى خوشَبختى رويم)

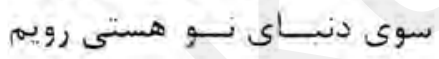

\section{?al}

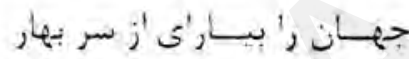

بيا 'ي فرح بخش فلب و دمأغ

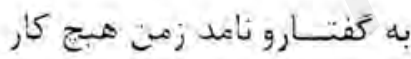

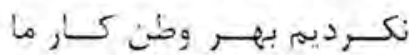

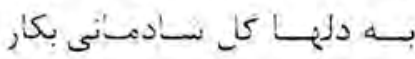

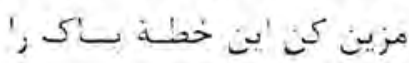

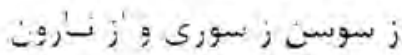

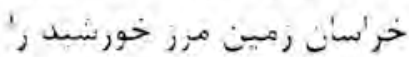

ببـا 'ي بيسار 'ى دعطر بهار

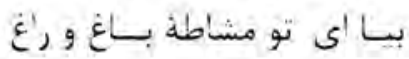
شب وروز فاددم زكف همجويلً

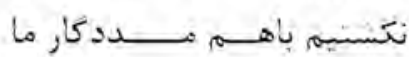

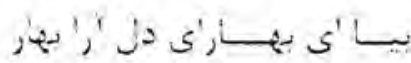

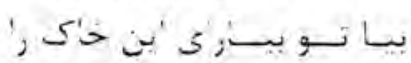

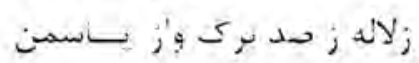

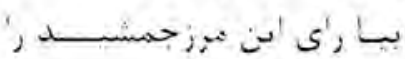

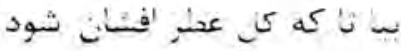

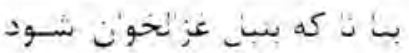




\section{مثنوى اين درس عشق و ارتقا است}

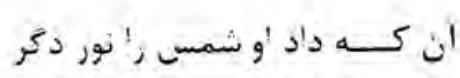

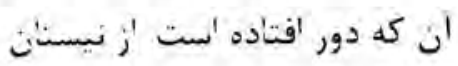

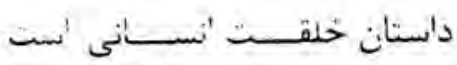

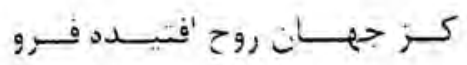

تا برد ر'هى به سوى 'حلا خويش

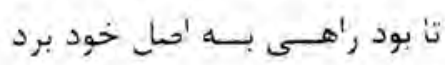

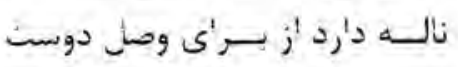

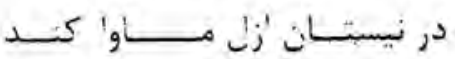

درس تسوحبد و نو'ى أشنـل 'ست
مولـوى أن عســـارف عالى كمثر

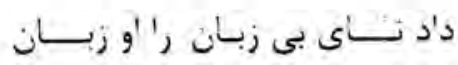

نسـانى 'و 'أنســدر نسو' نوفانى 'ست

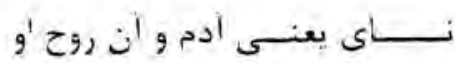

باز مى جويد همى 'و وصل خويش

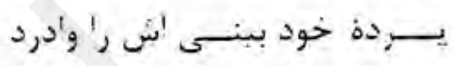

نالة 'و مســـوج إحساسات 'و 'بـت

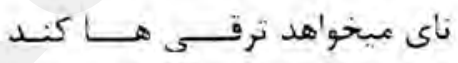

مثنوى'يندرسعشق و راتقاكس

نور دبــو'نش ز شمس 'نـوز 'ست

'ين ضياء هر رهروى ر' رهبر 'ست 


\section{بخش مستزاد}

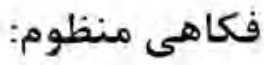

\section{از كج قلمك داد}

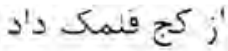

;' كج قلمكى د's

زين مرز' عموها

' كج قلمك טئ

بيند به تتو بيوز

ران كج فلمك داد

ميلر رَه تن 'و

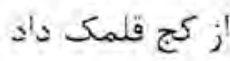

اجرا نكند كار

'ز كج قلمكى טاد

نق نق كند افززون

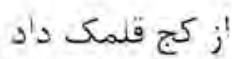

رنجد زتو بسيبز

ز' كج فنمك د'

تعجيل نمايد

;

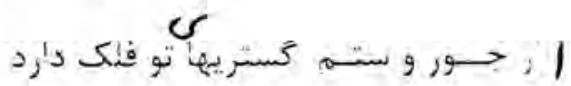

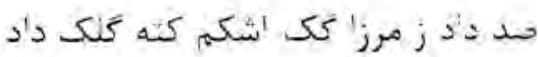

بأشد دل زار ضعفــا خون شنده هر جا

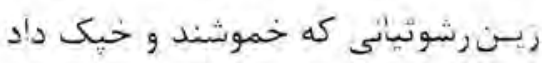

كـر دست به جبيت ببرى بهريكى كار

دلشاد شود ز آنكه بشد بيسه درك داد

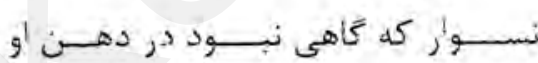

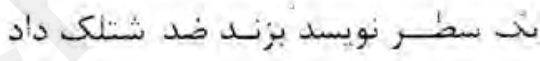

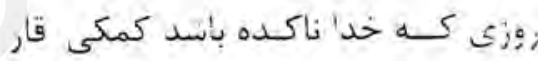

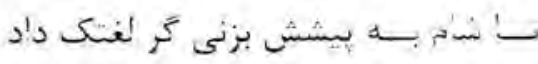

ميخردد به اندك سخنى زود جئر خون

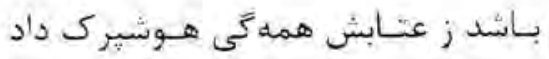
بيشش جـو شكايت كنى '; معطلى كار

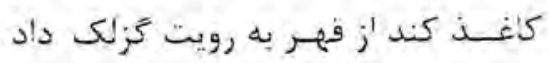

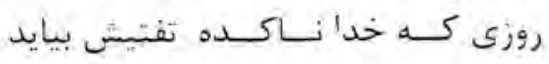

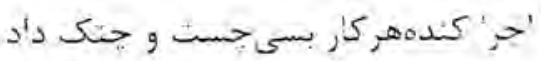




\section{تحصيل هنر كن}

تحصيل هنر كن

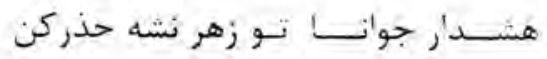

تحصيل هنر كن

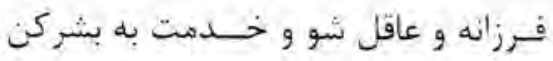

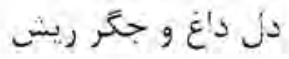

تحصيل هنر كن أخر شوى 'فيكار

تحصيل هنر كن عقريت روانت

تحصيل هنر كن

در كوى قمار 'ست

تحصيل هنر كن

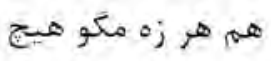

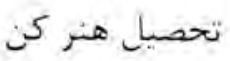

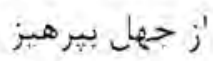
تحصيل هنر كن ني نئن يك آتش نسر كث كن كن نحصيل هنر كئ نـ تو هيج ندانى تحصيل هنر كن نديج ندني بيرى زسمد أخر هنر

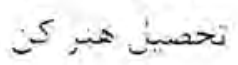
هـر نشا بود سخت يكى دشمن بدكيش

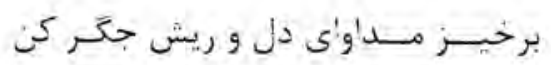

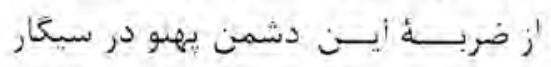

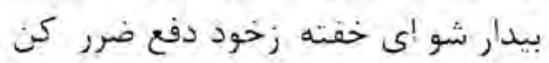

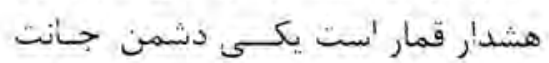

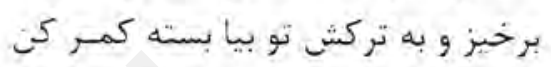

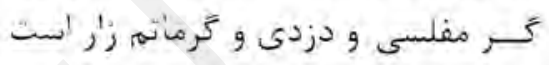

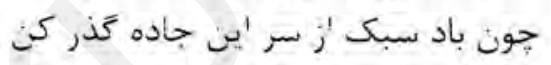
بيهوده جنين مست خر أمبده مرو هيج

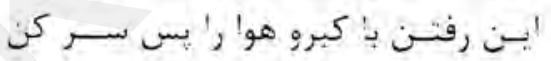
كويــد بدر هر لحظه كه با علهم در أويز

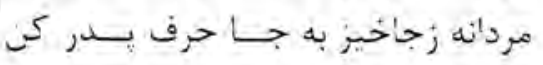

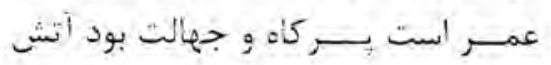

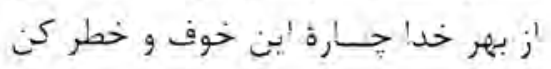

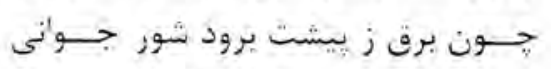

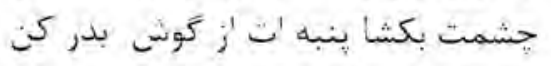

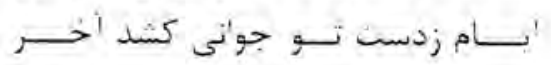

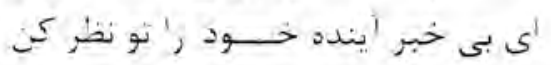




\section{فكاهى هنطوم:}

\section{قمار}

"ز دست فمار 'الست

'ز دست قمار 'ست

دوكني و سربيم

'ز دست قمار است

بُ ثروت و بازر

'ز دست قمار 'ست

دو كوجه وباز'ر

'ز دست قمار 'ست

در ناله زار اند

'ز دست قمار است

حرفى أست مبرهن

'ز دست قمار 'ست

خود نيز بسوزد

'ز دست قملر !ست

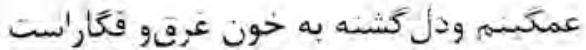

رسوى حهب تَثتسم و روزم شب تار 'ست

نفدى لدابه جسب 'ست و نمانده 'ست بر'يم

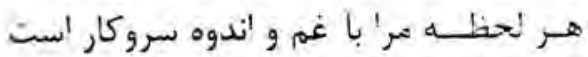

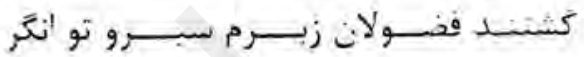

بأغ رغت وزمبئ رفته و قرضم صدهز'ر 'ست

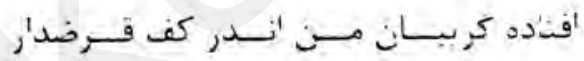

جـك نخنم يى حدو بيرون ز شمبار !بت

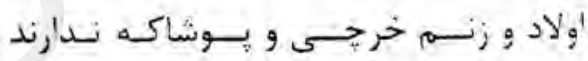

كـوبيند زملمست دل ما حمله فكـار 'ست

أرى بــود 'يسـن كَفته بـه يَبش همد روشن

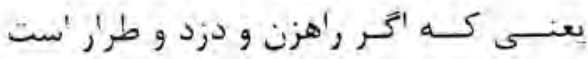

در انســ ايسن كـــار بلى 'و كـــــ فروزد

عمرش ز قمارش همه كى يكسره خو'ر 'نست 


\section{اين جهان زيبا است

$$
\begin{aligned}
& \text { بي حهان زيبا 'ست زيبا } \\
& \text { زندمنى زيبا تر و ورالا }
\end{aligned}
$$

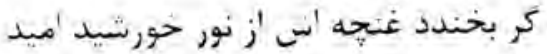

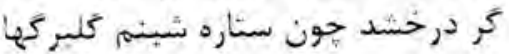
يع نسكون و با دوام

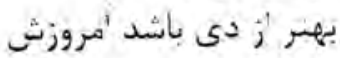

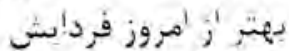
*** * * * 'ئ جهان زيباست زيبا

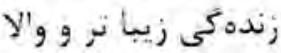

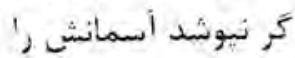

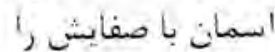

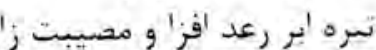

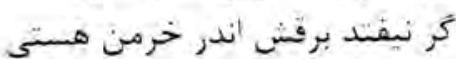

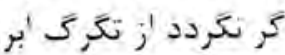
نو كلى يرير

* * * *

بي جهان زيباست زيبا

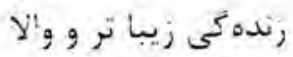
بسكند تبعيض رأكر رنك رنك

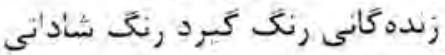

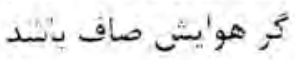

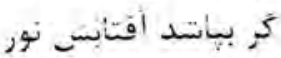
مى نخئدد كلا كَال 'ميد فردا هأى بهيتر ز زمسيس جز كالى شادى نرويد 
'بن جهبن زيباست ريبا

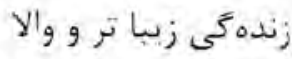

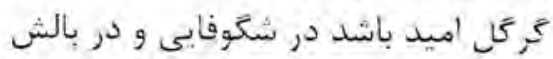

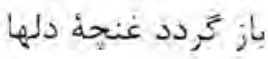

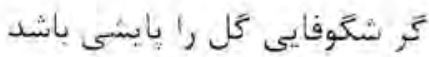

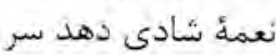

هر طرف أرى قناريهاي خونشبختى دهن سن * * * * * *

إين جهان زيباست زيبا

زندهكى زيبا تر و والان

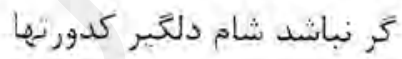

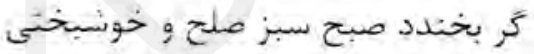

وندرين نور شفق داغ خود أكَاهى

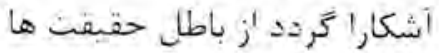

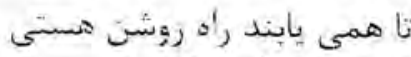
* * * * *

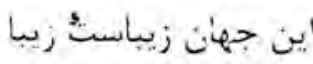

زندهى زيبا تر و و'لان

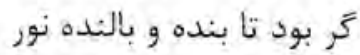

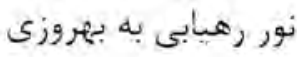

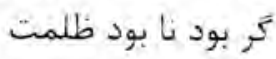

طنمت شوم إز فرأز ر'ه آدمهيا

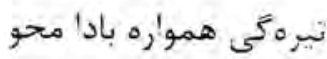

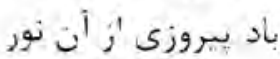




\section{مادر وطن}

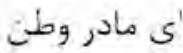

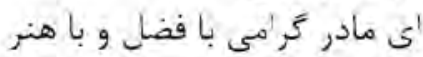

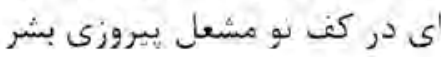

$$
\begin{aligned}
& \text { 'اي منيع 'مبد } \\
& \text { اميد جامعه 'ائر } \\
& \text { أى انكه بازويت }
\end{aligned}
$$

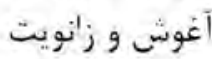

$$
\begin{aligned}
& \text { باشد نخست مكتب 'بناي روزثار } \\
& \text { * * * * * * * } \\
& \text { از من به تو سلام } \\
& \text { از از من بنه تو بيام }
\end{aligned}
$$

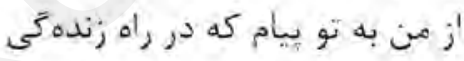

$$
\begin{aligned}
& \text { در عصر علهم و فين }
\end{aligned}
$$

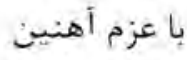

$$
\begin{aligned}
& \text { با قلب راستين }
\end{aligned}
$$


يرورده في تو دختر و فرزئد باهنر ير كار و رنجبر كر بام تأ به شام همى كار ميكند

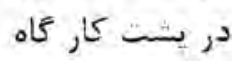

در بين كثمر'

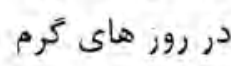

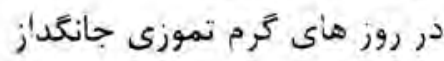
ريزد عرق براى خود و مردمان خويش

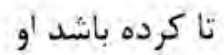
توليد بيشتر اينست الفتخار

ايتي أفتخار بو أست 'ى مأدر وطن

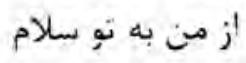




\section{ene}

$$
\begin{aligned}
& \text { بك روز تابناك } \\
& \text { يك روز بر فروغ و شكوهمنيندى آفرين }
\end{aligned}
$$

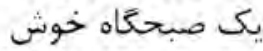

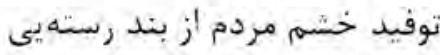

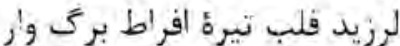

$$
\begin{aligned}
& \text { كرديذ سرنغَون }
\end{aligned}
$$

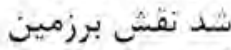

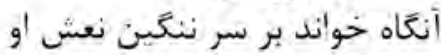

$$
\begin{aligned}
& \text { فرزند إين وطن } \\
& \text { اين نسلى آرين آنين } \\
& \text { اينك مقاومت بنك ارين } \\
& \text { اينك مقاومت كه ظفر آفرين بود } \\
& \text { راهى برد به يَيش }
\end{aligned}
$$

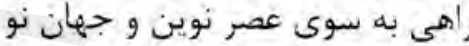

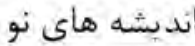

$$
\begin{aligned}
& \text { اين است شاهر اه رهايى توده ها }
\end{aligned}
$$

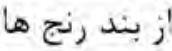

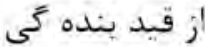

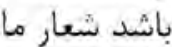

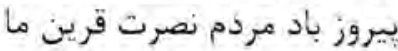

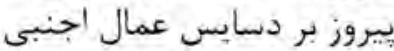

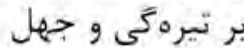

$$
\begin{aligned}
& \text { جاويد باد عصر نو انديشه نوين } \\
& \text { جاُويد فتح مردم تاريخ سازما } \\
& \text { ما يبيش ميرويم فئم مردم } \\
& \text { يبوسته و متّين } \\
& \text { با نسال بيشتاز و جهان سار أريا } \\
& \text { تا مرز افتضخار }
\end{aligned}
$$




\section{يرواز زندهى}

در ناكساي هجر نو اي ماه كم نما

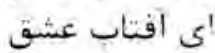

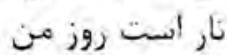

خواهم كه جلوه كر شوى أى برق أرزو در أسمان جان بر كشور دلم حان

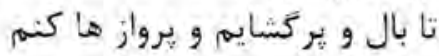

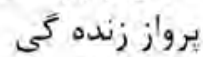
اندز فضاى عنق كيق عشفى كه رهنمون شودم تأ ديار راز آن إز سر به مهر رهبر * * * *

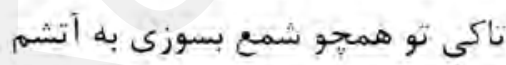

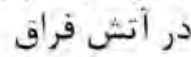

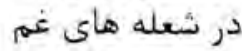
تا كى نميكنى به وفا شادم إى نيكار تا تخديد از تو دور تا تا جند انتظلار زود أ كه مبرود ز تنه جان بيقر ار

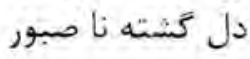
* * * * حون أفتاب كرم بهارى خروج كن

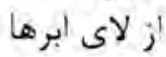
أز لاى أبرهاى ملال أوها فراق

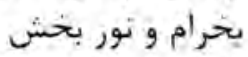
"ا بردمد ز نور جمالت به باغ دل كألهاى آرزو

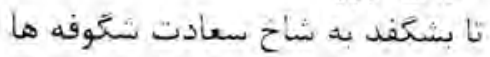
رنبى و جان فر' 
ارغوان

نور بهار أمد خرامان شد به كل غوندى نو عروس دلرباى 'رغوان

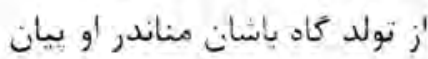

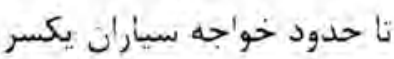
كشته امروز 'رغونى ز ز نسيم روح بخشي

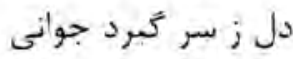
زانكه أبد أز فراز (شأميانه) ز زنار برفهيا از بر (نيلاب) ان درياى سرمست و خروشان

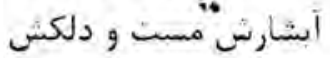
بليلانش نعمه بوداز

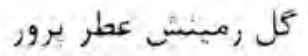
أسمانش ستئون

منظرش اكنون زيبا و برى وش لئري

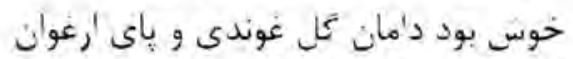
أز جمالث

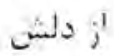

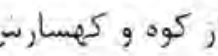

نشاط و حرمى خبزد حوش هو'يش

89 


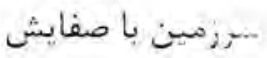

$$
\begin{aligned}
& \text { لالد ها و 'رعوبش بأش } \\
& \text { مشك ريزد عطر بيزد } \\
& \text { * * * * } \\
& \text { دشت و در } \\
& \text { كوه و كمر } \\
& \text { كنج و كنار دمه هـا }
\end{aligned}
$$

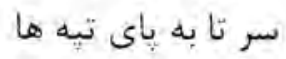

$$
\begin{aligned}
& \text { غرق موج خون بحر بيكران ارغوان } \\
& \text { * * * * * * * * } \\
& \text { خوشنما و دلربا } \\
& \text { غهم زدا فرحت فزا } \\
& \text { روح برور عشق إنخيز است آرى فر فر }
\end{aligned}
$$

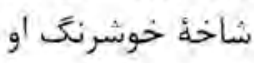

$$
\begin{aligned}
& \text { لعل وش ياقوت رنت } \\
& \text { مينمايد در نظر } \\
& \text { همجو رخسا, نغار سروقد و لاله خد } \\
& \text { خوشه هاى 'رغولن }
\end{aligned}
$$

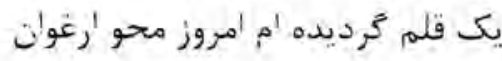

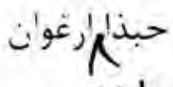

$$
\begin{aligned}
& \text { (s) }
\end{aligned}
$$




\section{شهر طلايى روز كاران}

دوش من ديدم به خواب خواب شهرى را كه اندر يار دوران روشن است

قصة هايش خوائ نتري

قصه هاى بار دورانش

قصه بشنيدن و بالبدن است دورنت

كر بحواهى ديد اين نسهر طلايى روزكار

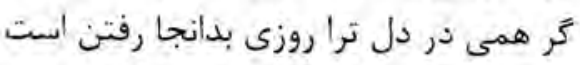

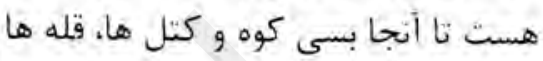

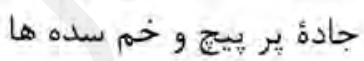
كوه ها رأ مى سير برخيز!

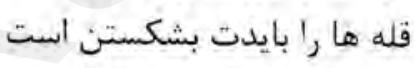

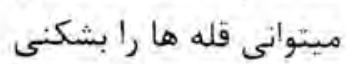

كر ترا همت به سان كوههاى آهن است " (ITAT) 


\section{سعادت}

$$
\begin{aligned}
& \text { اى سعادت أى اميد زندهكى } \\
& \text { اي كد نامت دليذير است } \\
& \text { أى كم بو روح حساتى } \\
& \text { ليكى افسوس هر قدر جشمى بمالمٍ } \\
& \text { باز هم أندر نأنم } \\
& \text { تو نظكردى آشكارا } \\
& \text { * * * * } \\
& \text { خوب مسانمم كه هستى } \\
& \text { در وجودت نيست شكى } \\
& \text { ليك از من ميكريرى }
\end{aligned}
$$

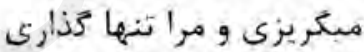

$$
\begin{aligned}
& \text { * * * * * } \\
& \text { تا كحا ها ميخريرى } \\
& \text { از جه رو تو ميكربرى } \\
& \text { نسيتى تو بهر هر كس؟ } \\
& \text { هسنى أرى بارير هركس. ليك أكون } \\
& \text { دست بي مهر زمانه } \\
& \text { بنجئ خو نحوار ايام }
\end{aligned}
$$

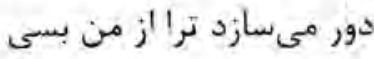

$$
\begin{aligned}
& \text { دور تر در ما وراي برده ها هـ } \\
& \text { بردة 'سر أر أهير } \\
& \text { برثدة مكر و فريب } \\
& \text { * * * * * }
\end{aligned}
$$




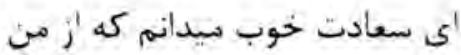

$$
\begin{aligned}
& \text { ابنحئين بهر هميشه } \\
& \text { تو نخوأهى ماند دور } \\
& \text { آخر آرى آتش خشيمى و سنير } \\
& \text { ميكثد روزى زبانه } \\
& \text { از كمينكاه هاى يأس }
\end{aligned}
$$

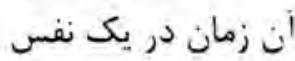

$$
\begin{aligned}
& \text { برده ها اين يرده هاي تيرة ادبار } \\
& \text { سوزد و گردند خاكستر } \\
& \text { 粦粦 * } \\
& \text { أندم أر يهناي دور } \\
& \text { از وراى آتش تابندة يأس و ستير } \\
& \text { از وراى شعله هاى خشم } \\
& \text { يرتو اندازد ز مهر } \\
& \text { بر سر إياى وجودم } \\
& \text { آفتاب نيكى بختى و سعادت } \\
& \text { * * * * * } \\
& \text { آن زمان است آنكه كردد } \\
& \text { قلب، اين قلب فسرده } \\
& \text { تا ابد لبريز از نور سعادت }
\end{aligned}
$$




\section{راه صلح}

$$
\begin{aligned}
& \text { ميرود اين تازه برنا سوى سنكر }
\end{aligned}
$$

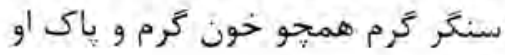

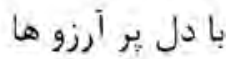

$$
\begin{aligned}
& \text { آرزوى زيستن، دامات كَتن. } \\
& \text { يك دو روزى شاد خئديدن }
\end{aligned}
$$

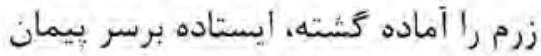

$$
\begin{aligned}
& \text { بر سر يِمان هستى ساز } \\
& \text { تا ظفر يا بد در اين يِيكار }
\end{aligned}
$$

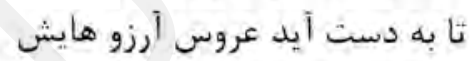

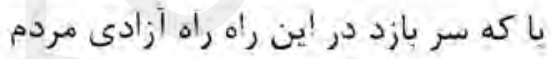

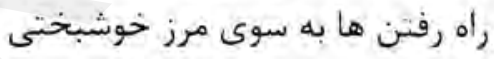

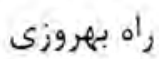

$$
\begin{aligned}
& \text { نيست او رازين دو راه راه ديخر رهى در بيمث } \\
& \text { يا ظفر يا مرى لئر }
\end{aligned}
$$

* * * *

$$
\begin{aligned}
& \text { از جه رو اين جنك } \\
& \text { يس حرا مردن }
\end{aligned}
$$

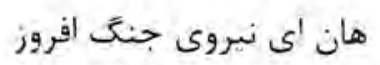

هست اينجا راه ديكر جاى جنَّ و مركى

$$
\begin{aligned}
& \text { راه صلح و راه آكاهى الهى } \\
& \text { راه آكاهى به روز روشن فرد' }
\end{aligned}
$$$$
\text { رإه بس دثوار آينده }
$$$$
\text { راه أبجاد جهان نو نوار انده }
$$

* * * * * 


$$
\begin{aligned}
& \text { مسرود 'ين بازمه برنا } \\
& \text { بوى سنكر. }
\end{aligned}
$$

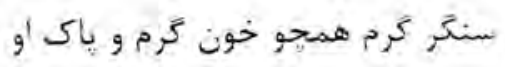
هست بحر 'و دلى اندر تبيدن

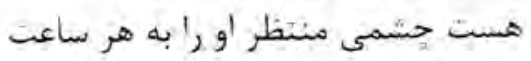
هست آن دل فلب يك مادر قلب ير احساس يك خواهر

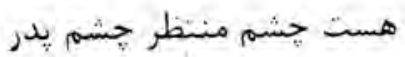

$$
\text { جشمى يك همسر }
$$

$$
\text { تا كشد أو راكه باز آمدن دمر بر مدر }
$$

تا همى بيند بدر روى يسر را باز

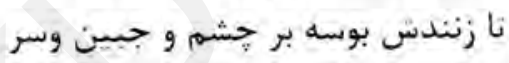

$$
\begin{aligned}
& \text { وقت بركثتن } \\
& \text { ** * * * } \\
& \text { سر كنيد آنغاه با هم } \\
& \text { نغمه شادى و خوشبختى } \\
& \text { شعر و أهنَ و سرود نو }
\end{aligned}
$$

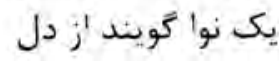

$$
\begin{aligned}
& \text { زنده و ياينده بادا صلح }
\end{aligned}
$$

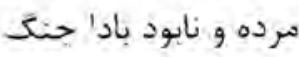

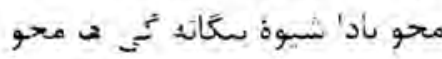

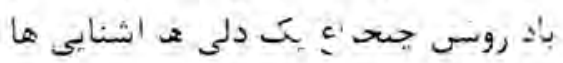




\section{مئن}

به تو اي ميهن اي جان و دلهم اي بر ترين آرزو هاب

عشّق مبورزم

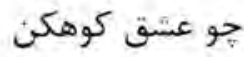
آن قلب و جان بسير دة شيرين * * * * * * به تو من عشق ميورزم به أن كوه هاى مير برف و فلك سايت

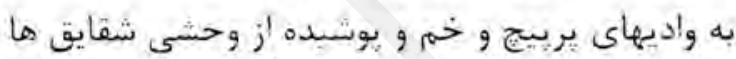
و وحشت أور از خود رسنه انسوه در, ختانت به آن لب تشنه حاصلخبر صحر 'هاى بهناور به آن عصيانتم آواره آب جويبارانت به فرزند دليرو رنج دوران دبده ات فرزند أز جا جسته با أرمان والابي 米米米

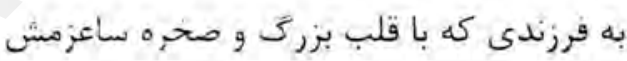
كناده راه بيروزى به سوى شئر هسنى ها به جانبز ربسالثمند و روسن بين امروزئ به دمقان جوان و كاركرهاى نو'نديشش درود و افنخار جاودان بادا * * * * * وطن:' أى مئن إى جان و دلهم أى برتربن آرزو هايم

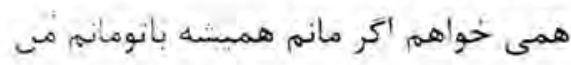


هميشه باتو 'ى ميهن

كه تا جشمان من روشن بود از مهر رخشاى مشئت

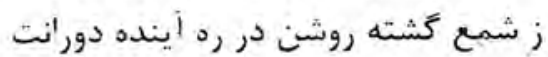
* * * * وكر ميروم

بميرم أى وطن اندر كنار ترومت

در قدومت،

تاكند لمس إين ركى و خونم

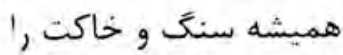

vV 


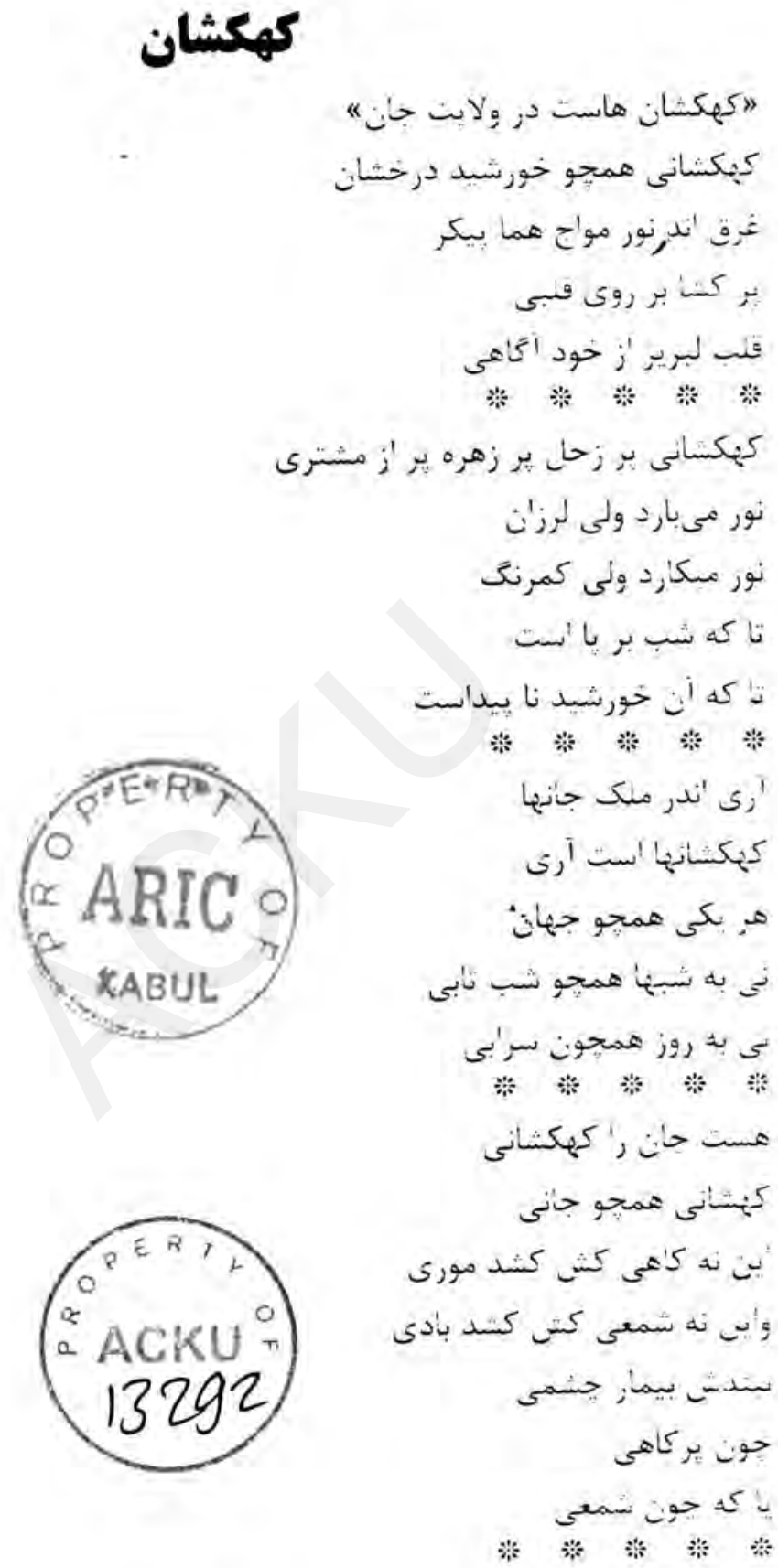




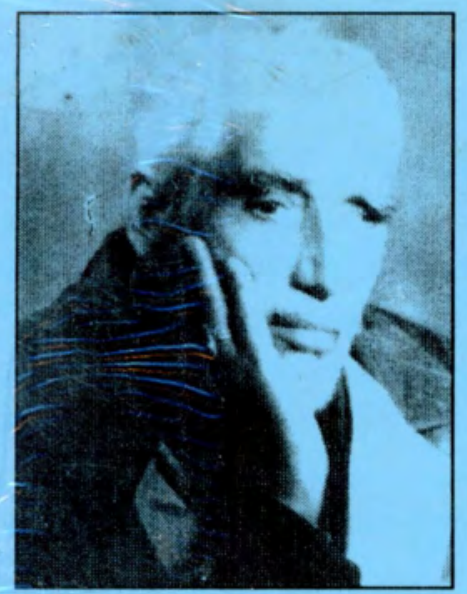

\section{KAHKASHAN}

a collection of poems

Poet:

Professor: Dr. M. Husain Yamin 